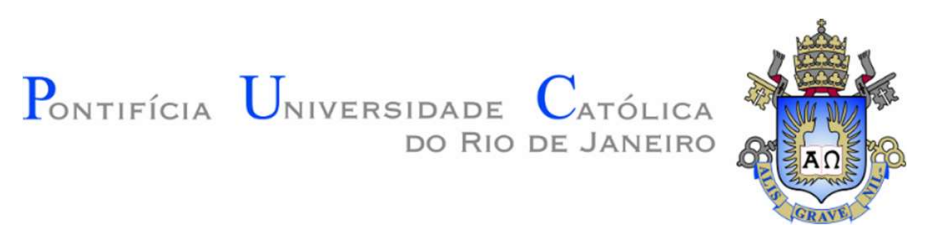

Suzanny Barreto da Silva

\title{
Como os Empregados Dão Sentido a Eventos
}

Organizacionais Traumáticos

Tese de Doutorado

Tese apresentada como requisito parcial para obtenção do grau de Doutor pelo Programa de Pós-graduação em Administração de Empresas do Departamento de Administração da PUC-Rio.

Orientadora: Profa. Dra. Flavia de Souza Costa Neves Cavazotte 


\section{Pontifícia Universidade Católica $_{\text {a }}$ DO RIO DE JANEIRO}

Suzanny Barreto da Silva

\section{Como os Empregados Dão Sentido a Eventos Organizacionais Traumáticos}

Tese apresentada como requisito parcial para obtenção do grau de Doutor pelo Programa de Pós-graduação em Administração de Empresas da PUC-Rio. Aprovada pela Comissão Examinadora abaixo.

Profa. Dra. Flavia de Souza Costa Neves Cavazotte

Orientadora

Departamento de Administração - IAG PUC-Rio

Profa. Dra. Alessandra de Sá Mello da Costa Departamento de Administração - IAG PUC-Rio

Prof. Dr. Christopher Norbert Stehr Hochschule Biberach University of Applied Sciences (HBC)

Profa. Dra. Isabel de Sá Affonso da Costa Universidade Federal do Rio de Janeiro (Coppead)

Prof. Dr. Sérgio de Souza Montalvão Departamento de Administração - PPGad UFF

Rio de Janeiro, 13 de maio de 2021 
Todos os direitos reservados. É proibida a reprodução total ou parcial do trabalho sem a autorização da universidade, da autora e da orientadora.

\section{Suzanny Barreto da Silva}

Graduou-se em administração na UFF (Universidade Federal Fluminense) em 2013. Concluiu o mestrado em administração na UFF em 2016. É administradora (servidora concursada) na UFF.

Ficha Catalográfica

Silva, Suzanny Barreto da

Como os empregados dão sentido a eventos organizacionais traumáticos / Suzanny Barreto da Silva ; orientadora: Flavia de Souza Costa Neves Cavazotte. - 2021.

117 f. : il. color. ; $30 \mathrm{~cm}$

Tese (doutorado)-Pontifícia Universidade Católica do Rio de Janeiro, Departamento de Administração, 2021.

Inclui bibliografia

1. Administração - Teses. 2. Identidade organizacional. 3. Identificação organizacional. 4. Evento organizacional traumático. 5. Sentido. I. Cavazotte, Flavia de Souza Costa Neves. II. Pontifícia Universidade Católica do Rio de Janeiro. Departamento de Administração. III. Título. 
Para meu marido, meus pais e irmã. 


\section{Agradecimentos}

À minha orientadora professora Flavia de Souza Costa Neves Cavazotte pelo estímulo e parceria para a realização deste trabalho. Seu cuidado e sensibilidade fizeram toda diferença.

Ao CNPq e à PUC-Rio, pelos auxílios concedidos, sem os quais este trabalho não poderia ter sido realizado.

Ao meu marido Mario por todo apoio, paciência e compreensão.

Aos meus pais, pela educação, atenção e carinho de todas as horas.

À professora Alessandra de Sá Mello da Costa, por ter apoiado o meu pré-projeto, o que possibilitou o meu ingresso no curso.

Aos professores que participaram da Comissão examinadora.

A todos os professores e funcionários do Departamento pelos ensinamentos e pela ajuda.

As pessoas que concederam as entrevistas que viabilizaram essa pesquisa.

Aos meus colegas da PUC-Rio.

O presente trabalho foi realizado com apoio da Coordenação de Aperfeiçoamento de Pessoal de Nível Superior - Brasil (CAPES) - Código de Financiamento 001. 


\section{Resumo}

Silva, Suzanny Barreto da; Cavazotte, Flavia de Souza Costa Neves. Como os Empregados Dão Sentido a Eventos Organizacionais Traumáticos. Rio de Janeiro, 2021. 117p. Tese de Doutorado - Departamento de Administração, Pontifícia Universidade Católica do Rio de Janeiro.

Esta tese investiga como eventos organizacionais traumáticos que envolvem a identidade organizacional afetam os seus empregados. A pesquisa buscou esclarecer a produção de sentidos dos empregados a partir desses eventos e as implicações de dinâmicas identitárias nesse processo. A tese é composta por três estudos, cada um abordando questões específicas de pesquisa. O Estudo 1 foi realizado com empregados da Vale SA após o desastre de Mariana em 2015 e investigou os sentidos atribuídos pelos empregados da Vale S.A. ao desastre de Mariana. Os resultados apontaram que a manutenção do vínculo empregatício influencia a mobilização de mecanismos de defesa do self, e que a intensidade da identificação organizacional define a quantidade e intensidade dos mecanismos mobilizados; o Estudo 2 foi realizado com empregados da Petrobras SA após o escândalo de corrupção de 2014 e analisou como os líderes enfrentaram esses eventos e os processos pelos quais eles deram sentido em resposta à crise. Os resultados indicam que a liderança executiva influenciou o sensemaking por meio de uma estratégia de sensegiving com vistas à reparação da IO, afastando o malfeito e reforçando os seus aspectos positivos. Já a liderança intermediária assimilou o sensegiving, na medida em que ele atendeu as suas próprias necessidades de construção de sentido e defesa do self e; o Estudo 3 foi realizado com empregados da BR Distribuidora após a privatização da empresa em 2019 e revelou os elementos críticos e os processos por meio dos quais os empregados deram sentido ao evento traumático. Os resultados revelaram que a intensidade de ameaça ao self determinou se o empregado vivenciou o fim da IO como mudança - nos casos em que a ameaça foi percebida como menos intensa - ou como perda - nos casos em que ameaça foi percebida como mais intensa. Assim, processos sociais de associação (encontrados na literatura) e dissociação (que emergiram da análise) com vistas a defesa do self e produção de sentido foram mobilizados e os sentidos resultantes foram condicionados à intensidade de ameaça ao self, independentemente, da manutenção ou não do vínculo empregatício. Todos os estudos foram baseados em entrevistas em profundidade e dados documentais e tiveram a análise de conteúdo como ferramenta analítica. A tese contribui para a investigação de como os empregados reagem a eventos organizacionais traumáticos e como processos identitários condicionam a produção de sentido a partir desses eventos.

\section{Palavras-chaves}

Identidade Organizacional; Identificação Organizacional; Evento Organizacional Traumático; Sentido 


\section{Abstract}

Silva, Suzanny Barreto da; Cavazotte, Flavia de Souza Costa Neves (Advisor). How Employees Make Sense of Traumatic Organizational Events. Rio de Janeiro, 2021. 117p. Tese de Doutorado - Departamento de Administração, Pontifícia Universidade Católica do Rio de Janeiro.

This thesis investigates how traumatic organizational events involving the organizational identity affect employees. The research sought to clarify employees' production of meanings from these events and the implications of identity dynamics in this process. The thesis comprises three studies, each addressing specific research questions. All three studies were based on in-depth interviews and documentary data and had content analysis as an analytical tool. Study 1 was carried out with Vale SA employees after the 2015 Mariana disaster, and investigated the meanings they attributed to the tragedy. The results showed the mobilization of several defense mechanisms, stronger in intensity and number among those still employed and highly identified with the company; Study 2 was carried out with Petrobras SA employees after the 2014 corruption scandal, and analyzed how leaders faced these events as well as the processes by which they responded to the crisis. The results indicate that top management leaders engaged in a sensegiving strategy to repaire the organizational identity, which sought to detach the wrongdoing from it while reinforcing its positive aspects. Middle level leaders assimilated the sensegiving, insofar as it met their own needs for meaning-building and self-defense; Study 3 was carried out with BR Distribuidora employees after the company's privatization in 2019, and unveiled critical elements and processes through which employees give meaning to such a traumatic event. The results suggest that the intensity of threat to the self experienced by employees is connected to the meanings they attributed to the end of organizational identity: as a change - in cases where the threat was perceived as less intense -, or as a loss - in cases where the threat was perceived as more intense. The analyses describes unfolding psicossocial processes of association (found in the literature) and dissociation (which emerged in the study). Resulting meanings seamed to be conditioned by the intensity of threat to the self, regardless the employment status employees mantained after the privatization. The thesis contributes to the investigation of how employees react to traumatic organizational events and how identity processes condition the production of meaning from these events.

\section{Keywords}

Organizational Identity; Organizational Identification; Traumatic Organizational Event; Sense 


\section{Sumário}

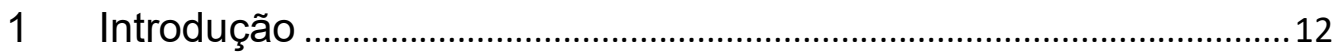

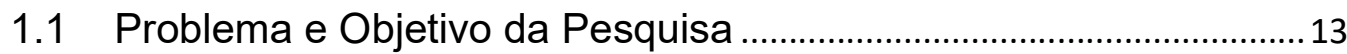

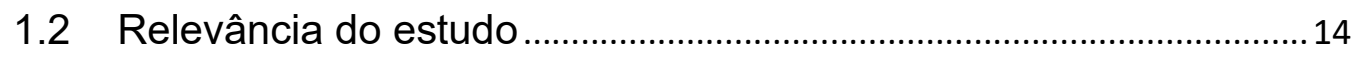

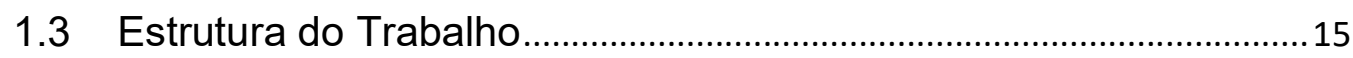

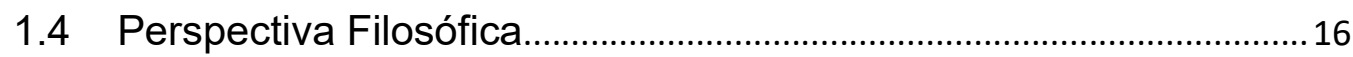

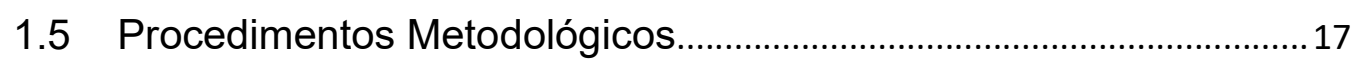

2 Embasamento Teórico ............................................................................ 19

2.1 Identidade e Identificação Organizacional .............................................19

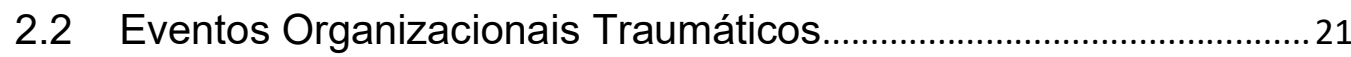

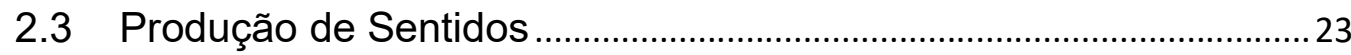

2.4 Produção de Sentido, Identidade e Eventos Organizacionais Traumáticos nos Estudos Brasileiros.......................................................2 26

3 Estudo 1 - Como empregados Dão Sentido à Má Conduta

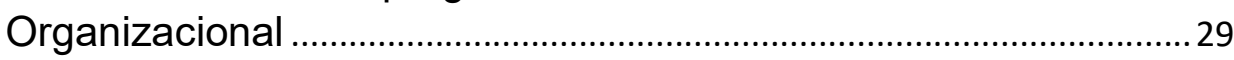

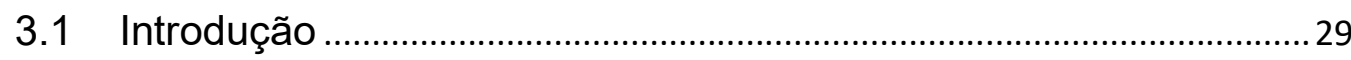

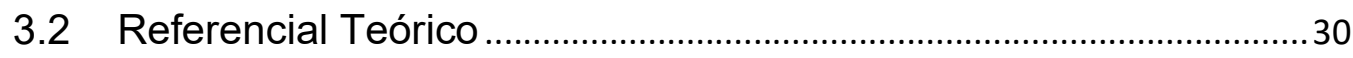

3.2.1 Crises, Identidade e Produção de sentido .............................................30

3.2.2 Identidade e Respostas a Crises Éticas Organizacionais .................31

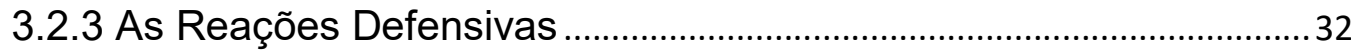

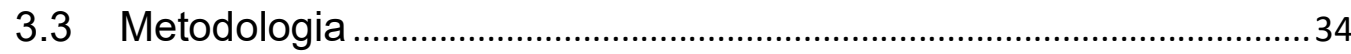

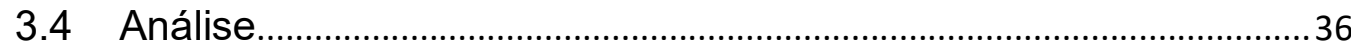

3.4.1 Trabalhadores Ainda Vinculados à Vale .................................................36

3.4.2 Empregados Não Mais Vinculados à Vale ...........................................40

3.5 Discussão dos resultados, achados e limitações .................................43

4 Estudo 2 - Como as Lideranças Dão Sentido às Crises Éticas

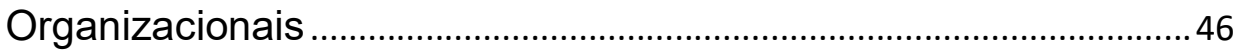

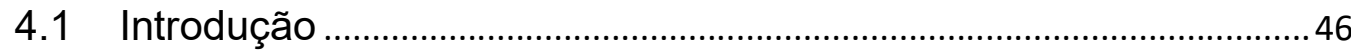

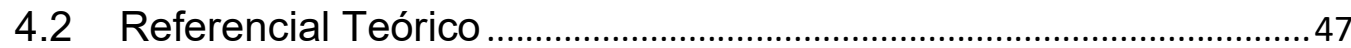

4.2.1 Crises e seu Impacto na Identidade Organizacional...........................47

4.2.2 Liderança e Sensemaking no Pós-Crise: Fraturas na Visão de Mundo e Perdas 
4.2.3 Liderança e Sensegiving no Contexto de Crises

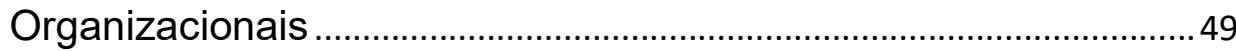

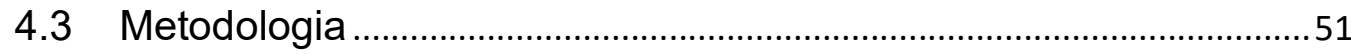

4.3.1 Entrevistas: Procedimento e Participantes.............................................52

4.4 Análise

4.4.1 Estratégia de Sensegiving da Liderança Executiva ...........................56

4.4.3 Sensemaking das Lideranças ................................................................. 73

5 Estudo 3 - Como os Empregados Dão Sentido ao Fim da

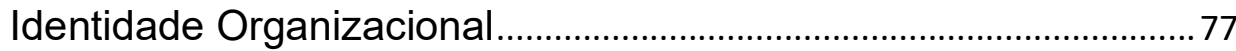

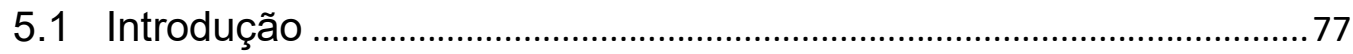

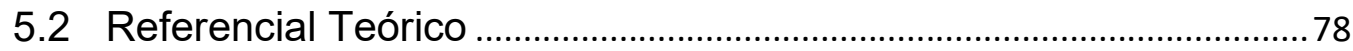

5.2.1 Processos Sociais, Identificação e Identidade.......................................78

5.2.2 Morte Organizacional e Sentidos ............................................................ 79

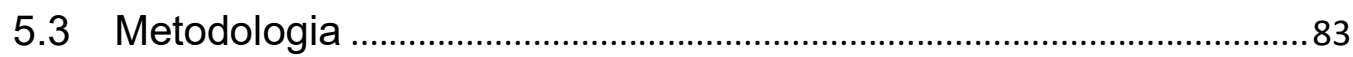

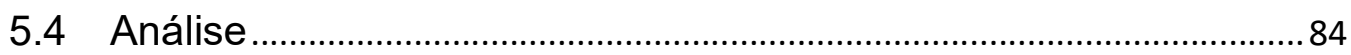

5.4.1 Os Processos Associativos de Enfrentamento ....................................86

5.4.2 O Processos Dissociativos de Enfrentamento..................................... 91

5.5 Discussão dos resultados, achados e limitações ...............................96

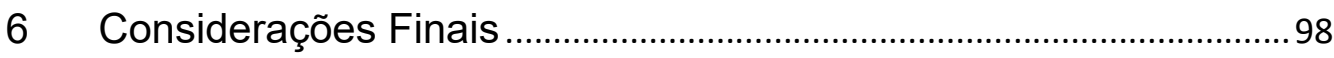

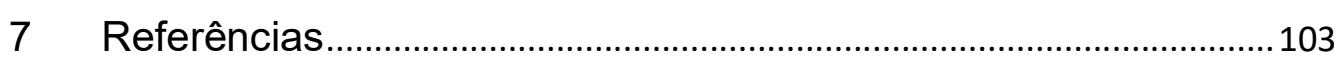




\section{Lista de Quadros}

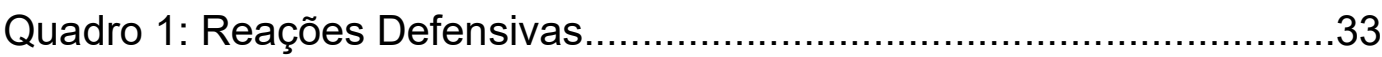

Quadro 2: Reações Defensivas da Identidade.........................................33

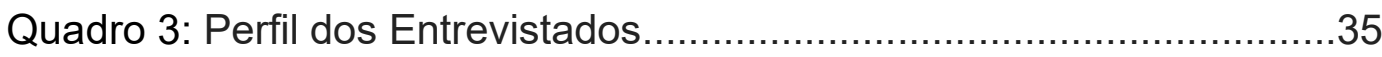

Quadro 4: Identificação e Sensemaking via Reações Defensivas (Funcionários Vinculados).................................................................39

Quadro 5: Identificação e Sensemaking sem reações defensivas (Exempregados - Não Vinculados)........................................................ 42

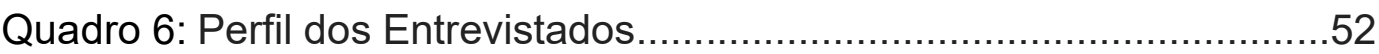

Quadro 7: Perfil dos Líderes Protagonistas.............................................53

Quadro 8: Processos Sociais Associativos..............................................79

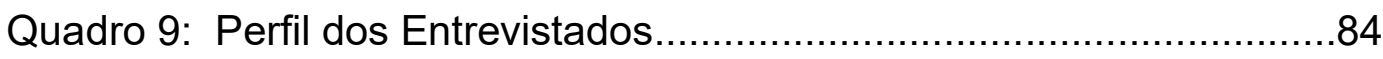

Quadro 10: Diferenças entre os Processos Sociais de Associação e Dissociação. 


\section{Lista de Figuras}

Figura 1: Eventos Organizacionais Traumáticos e Sentido:

Interpretações, Reações e Dinâmicas Identitárias

Figura 2: O Papel dos Vínculos na Respostas dos Empregados às

Crises Éticas.

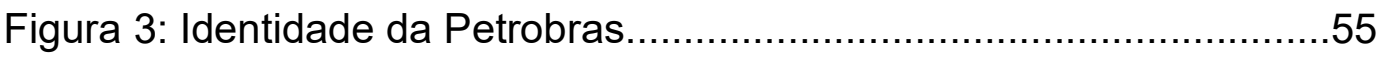

Figura 4: Não Existe Caminho Fácil. Existe Caminho Certo.......................59

Figura 5: Petrobras como Vítima dos Crimes de Poucos..........................61

Figura 6: Estratégia de Sensegiving da Liderança Executiva no

Sensemaking das Lideranças............................................................63

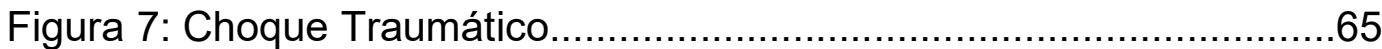

Figura 8: Fratura na Identidade Organizacional...................................69

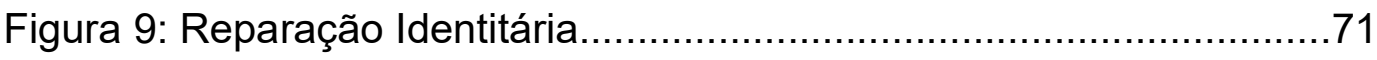

Figura 10: O Enfrentamento das Crises Éticas pelas Lideranças Intermediárias no Sensemaking das Lideranças.......................................72

Figura 11: Sensemaking das Lideranças.................................................74

Figura 12: Sensemaking em Resposta a Morte da Identidade

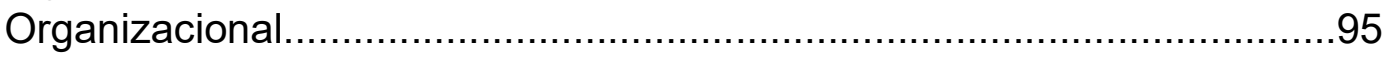

Figura 13: Eventos Organizacionais Traumáticos e Sentido: Resultados dos Três Estudos. 


\section{Introdução}

Nos últimos anos, empregados de grandes empresas têm vivenciado diversos eventos organizacionais traumáticos, desde crises associadas à má conduta organizacional (GREVE; PALMER; POZNER, 2010) - envolvendo contabilidade enganosa, maus tratos a empregados, produtos perigosos, degradação ambiental, entre outros (HERSEL; HELMUTH; ZORN; SHROPSHIRE; RIDGE, 2019; ALEXANDER et al.,2020) - até mudanças organizacionais profundas - como reestruturações, fusões, privatizações e falências (FERREIRA et al., 2010; CROSINA; PRATT,2019; MAITLIS, 2020). Esses eventos organizacionais traumáticos podem afetar profundamente os empregados dessas organizações (MAITLIS; SONENSHEIN, 2010) ao quebrar sentidos funtamentais que constiuem a identidade organizacional (WEICK, 1988). Em outras palavras, eventos organizacionais traumáticos que envolvem a identidade organizacional podem provocar uma crise de significados que corrói a estrutura básica de um grupo, que passa a buscar um novo sistema de significados que permita defirnir quem ele é e para onde vai (HIRSCHBERGER, 2018).

Esta tese reúne três estudos independentes realizados com empregados de empresas que passaram por eventos organizacionais traumáticos que envolvem a identidade organizacional, quais sejam: 1) um desastre ambiental e consequente crise provocados pela má conduta organizacional; 2) um escândalo de corrupção que levou a uma crise organizacional ética, e 3) um processo de privatização e consequente mudança radical no regime de funcionamento de uma empresa. Cada estudo endereça uma pergunta de pesquisa específica que tem como foco a vivência de um trauma organizacional pelos empregados dessas empresas. Os três estudos buscam analisar como empregados dão sentido e são impactados por eventos organizacionais traumáticos.

Esse processo de desenvolvimento de sentidos ficou conhecido como sensemaking a partir dos estudos organizacionais desenvolvidos por Weick (1988), e envolve elementos cognitivo-individuais, sociais-coletivos e/ou discursivos (MAITLIS, 2005). Esta tese aborda a produção de sentidos experimentada pelos empregados a partir de eventos organizacionais traumáticos, e pretende preencher lacunas no cruzamento entre níveis de análise (MAITLIS; CHRISTIANSON; 2014) 
ao investigar como dinâmicas que envolvem identidade e identificação organizacional são mobilizadas nesse processo.

\subsection{Problema e Objetivo da Pesquisa}

Seguindo a sugestão de Maitlis e Christianson (2014), esta tese amplia e aprofunda o entendimento sobre as reações dos empregados a eventos organizacionais traumáticos analisando como as dinâmicas e os processos que interconectam identidade e identificação organizacional condicionam a produção de sentidos a partir desses eventos. O estudo aborda um fenômeno que se dá no enclave entre os níveis organizacionais micro e meso buscando observar padrões em eventos, atividades e escolhas ao longo do tempo (LANGLEY; TSOUKAS, 2010).

Assim, a tese procura responder a seguinte questão central: Como os empregados dão sentido a eventos organizacionais traumáticos? O objetivo da pesquisa é analisar o impacto de eventos organizacionais traumáticos sobre os empregados, suas percepções e julgamentos sobre esses eventos, e as dinâmicas que envolvem identidade e identificação organizacional nessas interpretações. Para elucidar aspectos específicos dos processos desencadeados pela vivência desses eventos pelos empregados, a tese apresenta três estudos independentes que endereçaram perguntas de pesquisa específicas sobre o tema.

O estudo 1 analisa como eventos traumáticos que impactam a identidade organizacional mobilizam os vínculos identitários dos empregados dessas organizações. O estudo foi conduzido com empregados da Vale SA após o desastre ambiental de Mariana em 2015 e contribuiu para a literatura ao analisar as implicações do vínculo funcional e da intensidade da identificação organizacional na resposta dos empregados às alegações de má conduta organizacional.

O estudo 2 analisa como as lideranças enfrentam eventos traumáticos e como reagem a essas crises. $O$ estudo foi conduzido com empregados da Petrobras SA após o escândalo de corrupção na estatal em 2014, e contribui para a literatura ao analisar como as lideranças executivas constroem um sentido dominante em relação a um evento traumático, ainda que cada empregado vivencie individualmente o processo de sensemaking. $\mathrm{O}$ estudo analisa o papel das narrativas e enquadramentos construídos pela alta administração na reparação da identidade organizacional e na 
contenção da ameaça que a fratura na identidade organizacional, provocada pelo evento, representa para a identidade individual dos empregados.

O estudo 3 analisa como são os processos mobilizados pelos empregados para dar sentido a eventos traumáticos e seus elementos críticos. O estudo foi conduzido com empregados da BR Distribuidora durante a privatização da empresa em 2019, um evento traumático que envolve uma mudança radical na identidade organizacional. Esse estudo contribui para a literatura ao analisar o processo vivenciado pelos empregados para dar sentido a uma transformação radical na identidade organizacional, elucidando os mecanismos centrais desse processo.

Cada um dos estudos forneceu elementos que possibilitaram uma melhor compreensão de como os empregados dão sentido a eventos organizacionais traumáticos. A Figura 1 demostra de maneira concisa esse processo que é pormenorizado ao longo da tese.

Figura 1 - Eventos Organizacionais Traumáticos e Sentido: Interpretações, Reações e Dinâmicas Identitárias

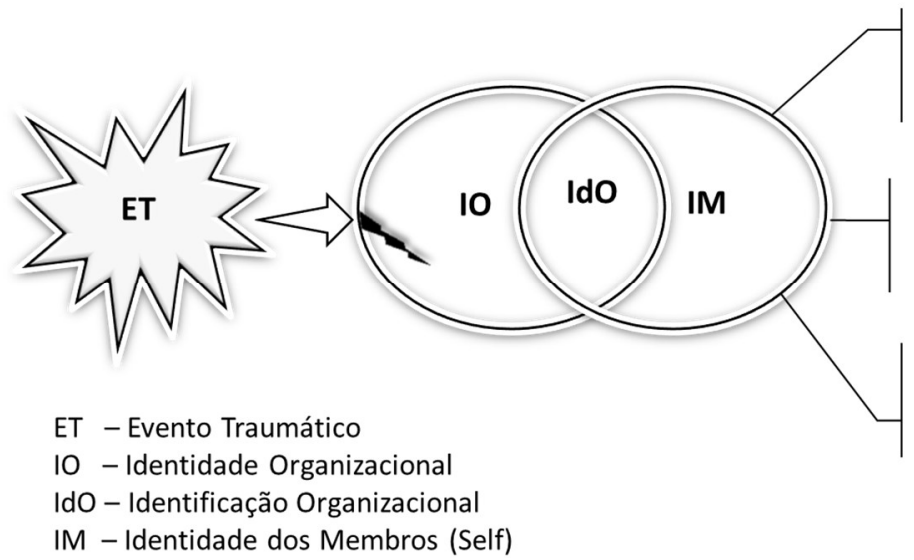

Interpretações dos

Membros I

Papel dos Vínculos (VALE)

Reações dos Membros |

Papel do Sensegiving

Executivo (PETROBRAS)

Dinâmicas Identitárias dos Membros |

Impacto nos Vínculos (BR)

Conforme a Figura 1, um evento organizacional traumático impacta a identidade organizacional e, potencialmente, a identificação organizacional e a identidade dos membros (self). Esse processo promove e influencia a produção de sentidos, que, por sua vez, irá influenciar a própria vivência do evento organizacional traumático, o ressignificando.

\subsection{Relevância do estudo}

De maneira geral, dentro e fora do ambiente do trabalho, o crescimento individual pós-traumático tem sido associado à força pessoal, à melhora no relacionamento com os outros, à valorização da vida, à abertura a novas 
possibilidades e à mudança espiritual e, no contexto do trabalho, ao bem-estar, a mudanças psicológicas positivas, à pró atividade na carreira, à liderança pró-social e outros resultados positivos (MAITLIS, 2020).

Apesar desses estudos sobre crescimento pós-traumático organizacional (organizational posttraumatic growth - OPTG) e sobre mudanças organizacionais positivas pós-trauma (CALHOUN et al., 2010) se concentrarem em contextos extremos, inerentemente traumáticos, como ambientes de conflito armado e profissões que prestam assistência a traumatizados, a literatura sobre crescimento pós-trauma em atividades "comuns" vem ganhando força (MAITLIS, 2020). Nessa literatura, podemos incluir estudos que analisam diferentes reações a esses eventos e como indivíduos se defendem de novas ameaças (e.g. STEIN, 2016), estudos sobre como eventos organizacionais traumáticos abalam as crenças e segurança emocional e o papel do suporte social e de uma cultura organizacional solidaria no processo de crescimento pós-trauma (e.g., MAITLIS, 2020) e estudos sobre respostas a esses eventos dentro das categorias cognitiva, estrutural e relacional pós-trauma (e.g., ALEXANDER et al., 2020).

Ainda assim, pouco se sabe sobre como os empregados, líderes e liderados lidam com esses eventos traumáticos e a influência da identidade e da identificação organizacional - fontes organizacionais de entendimento do mundo - nesse processo. Assim, a presente pesquisa busca aprofundar a compreensão dos processos de reação e enfrentamento de eventos organizacionais traumáticos nessas dinâmicas.

\subsection{Estrutura do Trabalho}

Esta tese apresenta no capítulo 2 uma revisão de literatura que apresenta os marcos teóricos e conceitos centrais que perpassam os três estudos empíricos realizados. A revisão abordou os temas identidade e identificação organizacional, eventos organizacionais traumáticos e produção de sentidos, bem como um levantamento dos endereçamentos sobre estes temas nos estudos organizacionais brasileiros. Nos capítulos seguintes são apresentados os três estudos independentes. Cada estudo inclui introdução que descreve os eventos traumáticos tratados, embasamento teórico, metodologia com contexto histórico da organização em questão, análise e discussão dos achados e limitações. No sexto capítulo são 
apresentadas as considerações finais, com a articulação das contribuições teóricas e práticas dos três estudos.

\subsection{Perspectiva Filosófica}

Esta tese adota uma abordagem fenomenológica. Nesse sentido, construtos/objetos do construtivismo - identidade, identificação, experiencia e produção de sentidos - foram centrais nos três estudo (PETIT; HUAULT, 2007). Além disso, no estudo 2 o construtivismo também foi adotado como abordagem metodológica, conforme distinção feita por Petit e Huault (2007). Ademais, o estudo 2 adotou a teoria de sensemaking de Weick (BROWN; COLVILLE; PYE, 2014) como orientação para aplicação do interacionismo no contexto organizacional (ALLARD-POESI, 2005; FINE, 2005).

Assim, são referências filosóficas desta tese:

i) a fenomenologia sociológica de Schutz (1979), que procura esclarecer como os indivíduos entendem, conceituam e criam teorias e interpretações a respeito do que acontece na vida cotidiana, por meio da experiência individual e de padrões preestabelecidos de relacionamentos sociais (WAGNER, 1979);

ii) o interacionismo simbólico, uma das escolas de pensamento que parte da fenomenologia (VERGARA; CALDAS, 2005) com uma abordagem sociopsicológica e sociológica que é conveniente para análises de processos de socialização e ressocialização, mobilização de mudanças de opiniões, comportamentos, expectativas e exigências sociais (CARVALHO; BORGES; RÊGO,2010). De acordo com essa perspectiva os eventos são compreendidos por meio de significados que, por sua vez, são elaborados e modificados nas interações sociais. Além disso, o interacionismo simbólico trata atualmente: das conexões entre os níveis de análise, reconhecendo que as instituições têm um papel importante na construção de significado e que existe um nível de análise intermediário, a mesoestrutura, além do micro e do macro; e do equilíbrio entre agência e estrutura, quer dizer, a estrutura pode ser compreendida como um ator na interação e por conseguinte, um ator na construção de significados (FINE, 2005);

iii) a perspectiva de sensemaking de Weick (1979), que semelhante ao interacionismo parte de uma visão subjetivista e processual da produção de sentido (LANGLEY; TSOUKAS, 2012). Destarte, para Weick, assim como a realidade, a própria organização é concebida como um processo contínuo de construção de 
sentidos elaborados por meio das interações (WEICK; SUTCLIFFE; OBSTFELD, 2005).

Isso posto, presumiu-se nesta tese que os significados são fundamentalmente situados e ativamente construídos por pessoas em interações, e que tais significados podem ser revividos ou elaborados e comunicados nas entrevistas realizadas em cada um dos estudos (ALLARD-POESI, 2005).

\subsection{Procedimentos Metodológicos}

Os três estudos apresentados nesta tese se baseiam em entrevistas qualitativas semiestruturadas realizadas com os (ex)empregados da Vale SA, Petrobras e BR Distribuidora, além de vídeos institucionais no estudo da Petrobras. A análise de conteúdo foi utilizada para compreender as diferentes dimensões de como os empregados dão sentido a eventos organizacionais traumáticos. Assim, os textos transcritos das entrevistas, que compuseram o corpus de análise, foram estruturados em unidades de significado, também chamadas de unidade de registro ou de análise, que podem ser palavras, frases ou parágrafos (CAMPOS, 2004; SILVA; FOSSÁ, 2015).

As unidades de análise foram classificadas e organizadas em categorias iniciais, intermediárias e finais. Essa categorização foi, em grande medida, do tipo dedutiva, também chamada de codificação orientada por conceito ou direcionada (HSIEH; SHANNON, 2005), isto é, com categorias apriorísticas (CAMPOS, 2004). Quer dizer, elas vieram da revisão da literatura. Nesse sentido, o objetivo desse tipo de análise é validar ou estender conceitualmente uma estrutura teórica ou teoria (HSIEH; SHANNON, 2005).

Segundo Hsieh e Shannon (2005, p.1277), a abordagem direcionada da análise de conteúdo "começa com uma teoria ou resultados de pesquisas relevantes como orientação para os códigos iniciais". As categorias apriorísticas aportadas nos estudos foram: 1) as reações defensivas da identidade discutidas por Vries e Balazs (2010) e Petriglieri (2011) no Estudo 1;2) as necessidades do self abordados por Ashforth, Harrison e Corley (2008) e os enquadramentos e narrativas tratados por Logemann, Rebecca e Cornelissen (2018) no Estudo 2 e; 3) os processos sociais associativos abordados por Lakatos (1990) no Estudo 3.

No entanto, essas categorias dedutivas, em alguns casos, não foram suficientes para capturar inteiramente os fenomenos observados nas entrevistas. Por 
isso, novas categorias também foram elaboradas: a reação defensiva da identidade nomeada vitimização no Estudo 1; as fases ou etapas do processo de enfrentamento das crises éticas pelas lideranças intermediárias, isto é, Choque Traumático, Fratura na Identidade Organizacional e Reparação Identitária no Estudo 2; e os Processos dissociativos de enfrentamento: o Descomprometimento, a Desidentificação e a Ressignificação de si no Estudo 3.

Em relação à validade da análise qualitativa de conteúdo, Elo et al. (2014) destacaram a importancia de relatar o caminho percorrido até o resultado, de maneira que os leitores e avaliadores possam compreender claramente a análise e as conclusões resultantes. Assim, o caminho percorrido na análise dos Estudos 1, 2 e 3 pode ser descrito em três fases, a saber (BARDIN, 2011): 1) pré-análise sistematização das ideias iniciais do referencial teórico, leitura do corpus de análise, seguida, também, de sistematização; 2) exploração do material - seleção das unidades de análise, “[...] classificação e agregação das informações em categorias [...]” (SILVA; FOSSÁ, 2015, p.4) e; 3) tratamento dos resultados, inferência e interpretação - compreender o conteúdo manifesto e latente no corpus de análise.

Ademais, para compreender a produção de sentido após os eventos traumáticos nas organizações em questão, foi necessário compreender os atributos centrais de suas identidades antes do trauma, a partir da perspectiva dos depoentes. Não é possível discutir eventos associado às empresas Vale SA, Petrobras e BR Distribuidora, sem considerar o que essas organizações representam no imaginário nacional e que lhes confere nos dias de hoje "uma legitimidade emocional tão profunda" (ANDERSON, 2008, p.30). Segundo Anderson (2008), a representação de nação está associada a símbolos e valores compartilhados por uma comunidade. Nesse sentido, empresas como a Petrobras, a Vale SA e a BR Distribuidoras fazem parte do panteão de símbolos nacionais brasileiros, por serem consideradas parte da história do desenvolvimento do país. Além de sua finalidade econômica, essas organizações evocam um valor simbólico, não só para aqueles que trabalham nelas como para toda a nação. Por isso, a metodologia dos estudos apresenta, também, o contexto histórico dessas organizações. 


\section{Embasamento Teórico}

Os três estudos conduzidos nessa tese tratam dos conceitos de identidade e identificação organizacional, eventos organizacionais traumáticos e produção de sentido. Esta seção apresenta esses conceitos e seus marcos teóricos.

\subsection{Identidade e Identificação Organizacional}

A identidade pessoal é o "eu individualizado" - define "quem eu sou", i.e., o conjunto de características idiossincráticas que distinguem um indivíduo do outro (ASHFORTH; HARRISON; CORLEY, 2008; BREWER, 1991). Já as identidades sociais são "categorizações do eu em unidades sociais mais inclusivas que despersonalizam o conceito de si" (BREWER, 1991, p. 476). São representações que compõe o autoconceito de um indivíduo associadas a identidades de grupo, i.e., ao conjunto de características que distinguem um coletivo social de outro. Assim, a identidade de um indivíduo é perpassada por várias identidades sociais que podem ser, inclusive, antagônicas em várias medidas.

Brewer (1991) argumenta que as identidades individuais são o resultado da tensão entre necessidades de similaridade e distinção em relação ao outro. Brown (2017) elencou cinco abordagens diferentes de identidade presentes nas pesquisas, quais sejam: i) discursiva - em que as identidades são construídas por práticas situadas de uso da linguagem, principalmente, por autonarrativas relacionais (distinguindo o eu do outro), em constante evolução, internalizadas e não necessariamente coerentes; ii) dramatúrgica - em que os atores interpretam suas identidades por meio de posturas físicas e faciais, exibições emocionais e comportamentos específicos; ii) simbólica - em que a identidade é moldada por meio da adoção, exibição e manipulação de objetos como o espaço do escritório, crachás e até vestuário; iv) sócio-cognitiva - em que a identidade é elaborada por meio de habilidades cognitivas e sensemaking, quer dizer, operações cognitivas em resposta a estímulo sociais e; v) psicodinâmica - em que as identidade são construídas por meio de operações de defesa do ego.

O conceito de identificação como um estado "refere-se à parte da identidade de um indivíduo que deriva de sua associação com um grupo social (por exemplo, uma organização ou ocupação)" (KREINER; HOLLENSBE; SHEEP, 2006, 
p.1032), e se refere a uma sobreposição de elementos constitutivos da identidade social sobre a individual (DUTTON; DUKERICH; HARQUAIL, 1994). É importante destacar, no entanto, que o processo de identificação está sujeito a várias influências, alternando-se com o tempo, o que pode impactar no nível de identificação (estado) de uma pessoa com qualquer identidade social. Isto é, a “identificação com” é dinâmica, e se altera ao longo do tempo (KREINER; HOLLENSBE; SHEEP, 2006, p.1032). E, como processo emergente de formação da identidade (BROWN, 2017), a identificação faz com que essa também seja fluída.

Para Ashforth, Harrison e Corley (2008), os indivíduos cada vez mais desejam algum tipo de identificação baseada no trabalho. Isso pode ser explicado pelas relações indivíduo-organização que estão cada vez mais tênues, além da necessidade de continuidade - em resposta às instabilidades da vida moderna - , de afeto e de pertencimento. Ademais, a identificação pode prover, ainda, outras necessidades do indivíduo, como autoconhecimento, autoexpressão, segurança, afiliação e redução de incerteza.

A identidade organizacional (IO) é uma representação compartilhada acerca de uma organização; é um atributo daquela coletividade, constituído reflexivamente através das impressões dos membros dessa empresa e de agentes externos a seu respeito (ALBERT; ASHFORTH; DUTTON, 2000). A IO é resultado da forma de ser, fazer e interagir daquela coletividade, manifesta de forma reconhecível na cultura de uma organização (MACHADO-DA-SILVA; NOGUEIRA, 2001), e responde à pergunta “quem somos nós?”. Já a identificação organizacional (IdO) diz respeito ao grau em que a autodefinição de um indivíduo é construída a partir do seu pertencimento a uma organização enquanto grupo social (ASHFORTH; HARRISON; CORLEY, 2008), definindo a importância e profundidade desse coletivo na definição de seu autoconceito.

A IdO, bem como a identificação com quaisquer grupos sociais, pode "[...] incluir congruência de valores, congruência de metas, outras características compartilhadas, uma ideologia relacionada à identidade e comportamentos consistentes de identidade" (ASHFORTH; HARRISON; CORLEY, 2008, p.328). O nível de IdO dos membros de uma organização pode trazer resultados positivos também para uma organização, promovendo: cooperação, esforço, participação e tomada de decisão organizacionalmente benéfica, motivação intrínseca, 
desempenho superior em tarefas, compartilhamento de informações e ação coordenada, diminuição da intenção de rotatividade e da rotatividade, melhor desempenho extra-papel, entre outros (ASHFORTH; HARRISON; CORLEY, 2008). Entretanto, uma total conformidade com a IO pode resultar em excessiva homogeneidade do grupo, prejudicando a criatividade e inovação (KREINER; HOLLENSBE; SHEEP, 2006).

Outras temáticas recorrentes nas pesquisas sobre identidade são as ameaças à IO, como os membros da organização respondem a essas ameaças e por quê (ELSBACH; KRAMER, 1996). Os pesquisadores procuram compreender como mudanças estratégicas, crises e traumas geram ambiguidade nos sentidos atribuídos a $\mathrm{IO}$ e quais os elementos que mediam a produção de sentidos dos membros (ELSBACH; KRAMER, 1996; MAITLIS; SONENSHEIN, 2010). Além disso, eles investigam como uma força de trabalho altamente identificada pode resistir às mudanças e não perceber uma crise, e como os líderes podem contornar esses efeitos (FIOL, 2002).

\subsection{Eventos Organizacionais Traumáticos}

Crises e traumas são eventos negativos que vão contra a concepção que a pessoa tem sobre o mundo e sobre si mesma no mundo (MAITLIS, 2020). Esses eventos podem ser devastadores, pois impactam suposições profundas que produzem um sentimento de segurança, desregulando cognições e emoções (MAITLIS, 2020). No nível coletivo, o trauma “[é] uma percepção gradual de que a comunidade não existe mais como uma fonte eficaz de apoio e que uma parte importante do self desapareceu" (ERIKSON, 1976, p.153-154). São considerados traumas enfrentados no trabalho as grandes mudanças, reestruturações, desastres e atendados (MAITLIS, 2020). Há ainda os casos de morte organizacional provocados por falhas na gestão do negócio, downsizing, fechamento de locais de trabalho e fábricas, reestruturação, fusões e aquisições (BELL; TAYLOR, 2011; ARMAN, 2014). Para Bell (2012), a morte organizacional é a perda da estrutura fundamental de significado do grupo, isto é, da identidade organizacional. Assim, por analogia, podemos entender que um trauma que não resulte em morte organizacional, no mínimo, abala a identidade organizacional.

As organizações são impactadas, direta ou indiretamente, por uma série de eventos traumáticos. São exemplos a crise econômica de 2008 e as medidas de 
austeridade observadas; os ataques terroristas de Nova York, Londres, Madrid, Paris ou Bruxelas, e; desastres climáticos como o furacão Katrina ou o desastre nuclear em Fukushima (PEÑA et al, 2017). Esses e outros eventos organizacionais traumáticos, como mudanças tecnológicas radicais ou pontos de viragem significativos nos ciclos de vida organizacionais, tem um efeito disruptivo e podem levar a padrões disfuncionais e a perturbações (WINTER, 2019), tal como em fusões, por exemplo, em que os empregados presenciam dispensas em larga escala e podem acabar se tornando vítimas secundárias (WINTER, 2019).

Não obstante, o conceito de trauma organizacional (TO) é bem menos compreendido que de trauma individual, sendo necessário um exame mais minucioso do tema. Peña et al (2017, p.13), após revisarem a literatura, chegaram a seguinte definição para o TO “"uma superadaptação’ de uma organização à ruptura de sua membrana emocional protetora, causada por um evento potencialmente traumatizante e envolvendo o aparecimento de distúrbios emocionais e organizacionais". Os autores sugerem que um TO inclui uma crise de identidade organizacional - em virtude de seu impacto sobre os princípios organizacionais fundadores, os pontos de referência do coletivo organizacional mas que uma crise de identidade organizacional não pressupõe um trauma, pois pode se tratar, apenas, de uma grande mudança, sem envolver violência nem sofrimento.

Apesar de alguns fatores terem o potencial de agravar e prolongar o TO - entre eles, cargas de trabalho excessivas juntamente com a complexidade crescente das tarefas, responsabilidades pouco claras e papéis insuficientemente definidos - e suas potenciais consequências - como o distanciamento do cliente e do comportamento cooperativo positivo, perdas de confiança e lealdade, estresse e ansiedade (WINTER, 2019) -, os estudos organizacionais têm abortado o TO, também, como uma oportunidade.

Na psicologia, Calhoun et al. (2010) propuseram um modelo para melhor compreensão de como um evento traumático como a perda de alguém próximo pode levar a importantes mudanças pessoais positivas. Para os autores, a perda, especialmente de forma inesperada, perturba as crenças do indivíduo sobre o mundo, o que, por conseguinte, o leva a um processo de reconstrução de entendimentos. E é essa a oportunidade para o crescimento pós-trauma. Assim, 
Calhoun et al. (2010) buscaram compreender em seu estudo os elementos que influem nesse processo de reconstrução, tornando-o positivo ou não.

Semelhante processo pode ser desencadeado por eventos traumáticos que são enfrentados no trabalho. Nesse sentido, Maitlis (2020) trata do crescimento póstraumático no trabalho, isto é, um processo de mudança positiva transformadora por meio do qual narrativas de crescimento são desenvolvidas, ou seja, narrativas de sobrevivência ao evento crítico e desafiador com destaque para o desenvolvimento de novas habilidades. Deste modo, esse processo envolve reduzir a importância atribuída a identidade organizacional anterior ao trauma e, ao mesmo tempo, construir uma nova identidade positiva pós-trauma.

Segundo Maitlis (2020, p. 402), para que o crescimento pós-traumático seja alcançado é necessário "um ciclo recursivo de regulação emocional e criação de sentido [...]" (Maitlis, 2020, p. 402). A pesquisa de Goltz (2018) se aproxima das reflexões de Maitlis (2020) em vários aspectos. A autora também chama a atenção para o impacto das emoções nas experiências de grandes mudanças organizacionais. Inclusive, Goltz (2018) afirma que um dos principais obstáculos à aceitação da mudança organizacional é o fato dessa, geralmente, representar uma ameaça à identidade e à autoestima associada a essa identidade.

\subsection{Produção de Sentidos}

As filosofias interpretativas (desenvolvidas em contraposição, principalmente, ao positivismo lógico do século XX) procuram compreender como os significados são desenvolvidos, expressos e comunicados por indivíduos e grupos dentro de um determinado contexto social (MORGAN, 2005; VERGARA; CALDAS, 2005; HATCH; YANOW, 2011). Dessa perspectiva, nem a realidade nem, tão pouco, o processo de conhecimento é objetivo, já que um novo conhecimento é desenvolvido a partir de outro conhecimento a priori que o moldará (HATCH; YANOW, 2011; LANGLEY; TSOUKAS, 2010).

Nesse sentido, Berger e Luckmann (1966) trataram do processo de interiorização, que é o meio pelo qual os indivíduos apreendem a realidade social que está fora deles (que é socialmente construída). Assim, a interiorização acontece por meio da imitação, em um primeiro momento, pela imitação do comportamento dos "significativos" - indivíduos que apresentam a realidade social. Assim, para 
Berger (1985, p.15 - 16) "[...] a sociedade é produto do homem e [...] o homem é produto da sociedade [...]", quer dizer, o processo social é fundamentalmente dialético. Se por um lado os indivíduos se reapropriam da realidade externa e trabalham com ela internamente, por meio da interiorização, eles, também, elaboram as estruturas objetivas do mundo por meio de seus elementos subjetivos quando interagem ao longo de sua vida cotidiana, o processo chamado de exteriorização (BERGER, 1985).

Ademais, “[...] a atividade do homem de construir um mundo, é sempre e inevitavelmente um empreendimento coletivo" (BERGER, 1985, p.20). Isso reforça a "instabilidade congênita" do mundo humano, o que resulta na necessidade constante de produzir sentido para o mundo e para si mesmo no mundo. Isso posto, é possível dizer que Berger e Luckmann (1966) procuram esclarecer a relação dialética entre cognição e estrutura social e os processos sociais pelos quais ocorre a produção de sentidos no mundo.

Já nos estudos organizacionais, a perspectiva do sensemaking foi introduzida por Karl E. Weick (1979), em um esforço, também, de mudar o foco de análise da "estrutura das organizações" e uma orientação positivista, para "os processos que constituem as organizações" (HATCH; YANOW, 2011).

Nesse sentido, o sensemaking, dentre outras definições, envolve “[...] processos pelos quais as pessoas procuram plausivelmente compreender questões ou eventos ambíguos, equivocados ou confusos" (BROWN; COLVILLE; PYE, 2014, p.3). Quer dizer, o sensemaking tende a acontecer quando as coisas não acorrem conforme o esperado (WEICK; SUTCLIFFE; OBSTFELD, 2005). No entanto, esta visão vem sendo reinterpretada, e autores contemporâneos a Weick (Maitlis, por exemplo) trabalham com a ideia de que o sensemaking é um processo contínuo do cotidiano, e que ele apenas fica mais evidente e intenso diante de questões ou eventos ambíguos, equivocados ou confusos.

Assim, “A organização emerge de um processo contínuo em que as pessoas se organizam para dar sentido [sensemaking][...]" (BROWN; COLVILLE; PYE, 2014, p.5) aos eventos que experimentam. Ademais, a organização é compreendida como uma abstração de padrões de comunicação interligados, atividades e escolhas ao longo do tempo, que os estudos organizacionais de processos procuram explicar (LANGLEY; TSOUKAS, 2010). 
Conceitos já discutidos nos estudos organizacionais como fenômenos estáveis podem ser abordados sob a perspectiva de processos (LANGLEY; TSOUKAS, 2010). Por exemplo, o conceito de identidade organizacional que passou a ser abordado como algo fluído, como "trabalho de identidade", o processo em que as pessoas se envolvem “[...] na formação, reparação, manutenção, fortalecimento ou revisão de construções que produzem um senso de coerência e distinção" (SVENINGSSON; ALVESSON, 2003, p.1165) da organização. Outrossim, as identidades individuais construídas no contexto organizacional têm sido também discutidas como processos narrativos (MACLEAN; HARVEY; CHIA, 2012).

Além disso, as pessoas constroem e promovem as suas próprias realidades por meio de ações (BROWN; COLVILLE; PYE, 2014). Quer dizer, agir sobre o evento ajuda a reduzir a equivocidade, e faz parte do processo de sensemaking (BROWN; COLVILLE; PYE, 2014). Destarte, para Weick (1988), por meio da ação “[...] o indivíduo experimenta, obtém feedback, aprende e desenvolve uma compreensão do ambiente. Além disso, a ação moldará no que se está prestando atenção e fazendo e, consequentemente, moldará o próprio evento - a própria realidade (WEICK, 1988).

O sensemaking é mediado pela linguagem e experiências anteriores (conhecimentos a priori), isto é, o indivíduo atribuirá sentido para o evento conforme for capaz de traduzi-lo em palavras e em comparação com outras vivências (WEICK, 1988; WEICK; SUTCLIFFE; OBSTFELD, 2005). Dito de outra maneira, ele compreende o evento conforme for capaz de organizar os seus pensamentos a respeito do que ocorreu em um discurso mais ou menos coerente, delimitado pela linguagem e conhecimentos pregressos. Nas palavras de Langley e Tsoukas (2012, p. 5), “[...] os enunciados atuais dependem essencialmente de enunciados passados”. Para Weick, Sutcliffe e Obstfeld (2005, p. 409) “[...] o sensemaking é, principalmente, uma questão de linguagem, conversa e comunicação".

Deste modo, o sensemaking vai além da interpretação de um evento confuso, pois nesse processo os indivíduos não se restringem a tentar descobrir a realidade sobre o que aconteceu ou está acontecendo, mas eles geram a realidade que interpretam. Nele, “As pessoas que atuam nas organizações geralmente produzem estruturas, restrições e oportunidades que não existiam antes de agirem" (WEICK, 
1995, p.306). E, esses condicionantes criados pela ação (que integra o sensemaking) podem tanto contribuir para a origem de crises quanto podem torná-las mais gerenciáveis e assim, menos perigosas (WEICK, 1995). Depois de agir, esses mesmos indivíduos compreenderão a "sua" realidade do evento, retrospectivamente, por meio de ciclos contínuos de descoberta e invenção (MAITLIS; CHRISTIANSON, 2014).

Assim, uma importante discussão no campo dos estudos organizacionais é o sensemaking no contexto de crise. E, no cerne dessa discussão está a identidade organizacional. Em outras palavras, o sensemaking nas organizações (e em todo grupo social) está fortemente atrelado a IO, uma vez que a visão de mundo, a forma de ser, fazer e interagir predominantes na organização atuará na constituição dos sentidos possíveis àquele grupo (ASHFORTH; HARRISON; CORLEY, 2008).

Deste modo, as crises organizacionais podem provocar questionamentos a pressupostos institucionais fundamentais (EBERLE; CASALI, 2012), podendo inclusive criar ambiguidades que ameaçam as qualidades atribuídas à IO. No limite, as crises podem levar ao chamado sensebreaking - que é a destruição, quebra ou perda de sentidos fundamentais (MAITLIS; SONENSHEIN, 2010). Essa situação é desconfortável tanto no nível individual quanto no nível organizacional, o que compele os indivíduos à busca por sua resolução, ou seja, desencadeia o processo de sensemaking para responder à disparidade (CORLEY; GIOIA, 2004).

Assim, tendo em vista as interfaces entre identidade e identificação organizacional, eventos organizacionais traumáticos, sensemaking e, ainda, os últimos acontecimentos envolvendo importantes empresas brasileiras, como a Vale SA, Petrobras e BR Distribuidora, a próxima seção apresentao atual estado dessas discussões sobre esses temas nos estudos organizacionais brasileiros.

\subsection{Produção de Sentido, Identidade e Eventos Organizacionais Traumáticos nos Estudos Brasileiros}

Para buscar compreender o atual estado das discussões a respeito da produção de sentido no contexto de eventos organizacionais traumáticos nos estudos organizacionais brasileiros, realizou-se uma pesquisa sistemática da literatura nas plataformas Scielo.ORG, Scopus e Spell. Apenas seis estudos da seleção guardam alguma transversalidade com a discussão desta tese, qual seja, "como os 
empregados dão sentido a eventos organizacionais traumáticos" com foco nas questões identitárias e abordagem processual.

Sobral et al. (2020), por exemplo, tratou da estratégia de comunicação das lideranças políticas durante a crise decorrente da pandemia da COVID-19. Os autores concluíram que o tom da mensagem, otimista versus pessimista, tem implicações significativas para os níveis de ansiedade e para avaliação da transparência do governo e da sua resposta geral à crise. Já o conteúdo da mensagem, geral/abstrata versus específica, é menos importante.

Azevedo et al. (2017) discutiram uma mudança organizacional, a implementação de ferramentas e procedimentos da qualidade total em um hospital público brasileiro. Em resumo, o estudo descreveu como os instrumentos da qualidade total racionalizaram procedimentos e rotinas e, consequentemente, colaboraram na construção de sentidos.

Santos, Bandeira-de-Mello e Cunha (2016) analisaram uma crise em uma distribuidora de energia elétrica decorrente do rompimento de alguns de seus cabos de distribuição, o que deixou uma cidade inteira sem energia elétrica por, aproximadamente, 52 horas. Eles identificaram cinco categorias de desafios de liderança para responder à crise e as relacionaram às cinco tarefas de liderança em crise segundo Boin et al. (2005 apud SANTOS; BANDEIRA-DE-MELLO; CUNHA, 2016).

Alves e Guimarães (2014) buscaram compreender as narrativas encenadas pelos atores - empresa, órgãos públicos, políticos, sindicatos, advogados, promotores e comunidade - em torno de um desastre ambiental de base organizacional, o caso de poluição decorrente do armazenamento e despejo de produtos químicos tóxicos pela Shell na Vila Carioca, em São Paulo. Os autores revelaram como esses atores selecionaram significados e procuraram legitimar suas narrativas contornando suas contradições a fim de manter suas identidades primordiais.

Eberle e Casali (2012) analisaram uma crise organizacional ocorrida em um hospital público decorrente da pandemia de influenza A (H1N1). A principal contribuição desse estudo foi a análise da crise a partir de uma abordagem processual. Assim, os autores indicaram como os processos de sensemaking realizados pelos empregados exerceram influência no modo como eles agiram na crise organizacional. 
Por fim, Silva e Vergara (2003) procuraram compreender que significados a mudança intencional nas organizações, um evento potencialmente traumático, assume para os indivíduos; que sentimentos são despertados pela mudança e; que aspectos impactam a possibilidade de que esses indivíduos se constituam como atores conscientes ou sujeitos capazes de assumir um sentido e um rumo para sua atuação e, na hipótese mais favorável, até sentir-se como agentes da mudança. Para os autores, não há uma interpretação comum, nem mesmo um único tipo de significado atribuído por cada indivíduo à mudança organizacional. Silva e Vergara também destacaram características do contexto organizacional que podem facilitar e outras que podem dificultar o processo de subjetivação.

Assim, analisando o estado da arte sobre o assunto no Brasil pode-se dizer que há uma desconexão nas temáticas e abordagens, apesar da coincidência em relação ao contexto de crise ou mudança. Quer dizer, Sobral et al. (2020) tratam de estratégia de comunicação, Azevedo et al. (2017) tratam da estratégia de mudança organizacional a partir de uma abordagem descritiva, Santos, Bandeira-de-Mello e Cunha (2016) tratam a gestão da crise também a partir de uma abordagem descritiva, Eberle e Casali (2012) analisam narrativas na construção de sentidos em torno da crise, sem analisar a perspectiva dos empregados, e Silva e Vergara (2003), que mais se aproximaram da discussão desta tese, não aplicaram uma abordagem focada em processos.

Deste modo, a contribuição dos três estudos a seguir vai além do que foi observado na literatura brasileira, isto é, aplica uma abordagem interpretativa, focada na experiência dos empregados no contexto de crise, e analisa a fundo os processos psicossociais envolvidos. Além da atenção ter sido deslocada das ações e decisões organizacionais (como a empresa gerencia a crise) para a experiência dos membros da organização nesse contexto (como os empregados vivenciam a crise). 


\section{Estudo 1 - Como empregados Dão Sentido à Má Conduta Organizacional}

\subsection{Introdução}

Em novembro de 2015, testemunhamos o rompimento da barragem de Fundão em Mariana, controlada pela Samarco Mineração S.A. em conjunto com a Vale S.A. e a anglo-australiana BHP Billiton, que provocou o vazamento de aproximadamente 40 milhões de metros cúbicos de lama de rejeitos de minério e sílica, matando 19 pessoas (entre moradores e empregados da empresa), afetando 41 cidades (nos estados de Minas Gerais e no Espírito Santo) e provocando a degradação de cerca de 240 hectares de Mata Atlântica - na época considerado o maior desastre ambiental da história do Brasil (VORMITTAG; OLIVEIRA; GLERIANO, 2018; LACAZ; PORTO; PINHEIRO, 2017).

Em um contexto no qual crises ocasionadas pela má conduta de empresas adquirem cada vez mais visibilidade, como eventos traumáticos que impactam a identidade organizacional mobilizam os vínculos identificatórios dos empregados dessas organizações? Este estudo objetiva compreender as percepções e julgamentos de empregados sobre eventos de má conduta que provocaram crises éticas organizacionais.

A pesquisa investiga os sentidos atribuídos pelos empregados da Vale S.A. ao desastre de Mariana, com base em entrevistas realizadas com empregados vinculados à empresa durante o período da crise provocada pelo desastre, e ressalta as dinâmicas entre a identificação organizacional ea produção de sentido, a partir das narrativas dos empregados sobre o desastre.

Assim, o estudo 1 amplia e aprofunda o entendimento sobre as dinâmicas da produção de sentido no contexto de crises organizacionais, em particular crises que envolvem desvios de conduta de empresas, expandindo esse campo de conhecimento (JAMES; WOOTHEN; DUSHEK, 2011). Estudos anteriores enfocaram, principalmente, o nível organizacional e institucional, com menor atenção aos processos individuais. Também contribui para a compreensão sobre respostas individuais, chamando atenção para o papel das identidades sociais nos processos de atribuição de sentido no contexto de crises, e observando sua associação com o acionamento de mecanismos de defesa para dar sentido à má 
conduta da empresa. Os resultados foram sintetizados em um modelo conceitual que clarifica o processo de criação de sentidos pós-crise, que destaca a relação entre identificação organizacional, ambiguidades/ameaça percebida e mecanismos de defesa da identidade.

\subsection{Referencial Teórico}

\subsubsection{Crises, Identidade e Produção de sentido}

As crises organizacionais podem mobilizar ou criar ambiguidades sobre a identidade de uma organização. Uma crise organizacional é "um evento de baixa probabilidade e alto impacto que ameaça a viabilidade da organização e é caracterizado pela ambiguidade de causa, efeito e meios de resolução, bem como pela crença de que as decisões precisam ser tomadas rapidamente" (PEARSON; CLAIR, 1998, p. 60). Este tipo de evento frequentemente provoca rupturas e instabilidade na empresa e em seus membros, o que tem implicações não apenas para a tomada de decisão dos agentes nesse contexto, mas também para as atitudes e comportamentos de todos os seus atores (JAMES; WOOTHEN; DUSHEK, 2011; MAITLIS; SONENSHEIN, 2010). Eberle e Casali argumentam que as crises organizacionais provocam questionamentos a pressupostos institucionais fundamentais, podendo inclusive rompê-los, ameaçam a IO e, por conseguinte, as identidades individuais (2012).

Discussões sobre como organizações e seus membros atuam durante crises têm se apoiado na literatura sobre sensemaking - o processo por meio do qual as pessoas buscam traduzir suas experiências em modelos representativos possíveis e socialmente sancionados por grupos de referência (WEICK, 1995). Isto é, como as pessoas dão sentido ao que ocorre a sua volta com base em seus próprios modelos mentais e, também, nos sinais que capturam do ambiente e de seus principais atores. As imagens que são formadas nesse processo são fruto da imaginação e interpretação dos indivíduos e da sua necessidade de coerência cognitiva, individual e com a coletividade. Para WEICK (1995, p.11), as organizações são "[...] coleções de pessoas tentando dar sentido ao que está acontecendo ao seu redor". Assim, as imagens se tornam racionais dentro do contexto social, visto que foram construídas para representar situações criadas ativa e reflexivamente pelos atores do ambiente. 


\subsubsection{Identidade e Respostas a Crises Éticas Organizacionais}

Apesar da influência das diversas fontes de entendimento, a identidade é a principal referência para que o coletivo organizacional construa os sentidos necessários e compreenda sua experiência (MAITLIS; SONENSHEIN, 2010). No entanto, sentidos positivos atribuídos a IO podem estar associados à própria origem de crises (MAITLIS; SONENSHEIN, 2010). Por exemplo, em razão do otimismo e sensação de controle, problemas importantes podem acabar sendo negligenciados, levando à crise. Além disso, essa lógica institucional ao longo do tempo pode forjar identidades afeitas a riscos. Um exemplo disso é a identidade de "homens de verdade", que criou uma mentalidade de invulnerabilidade entre os mineiros de Westray (MAITLIS; SONENSHEIN, 2010). Essa identidade fez com que os empregados negligenciassem perigos potenciais, o que resultou em um dos piores desastres de mineração no Canadá.

Já quando há criação de sentidos positivos posteriormente a crises, os estudos mostram um efeito positivo sobre a organização e seus membros. Ao adotarem um discurso positivo após o colapso do telhado do Baltimore e Ohio Rail Road Museum, os executivos da organização engajaram-se no discurso de que a organização estava entrando em uma trajetória de renovação e crescimento (MAITLIS; SONENSHEIN, 2010). Assim, eles buscaram criar novos sentidos e auxiliar a recuperação organizacional.

Semelhante à criação de sentidos positivos, as identidades assumidas pelos indivíduos também podem ter implicações positivas ou negativas. A identidade pode servir de norte para que as pessoas atravessem uma crise, mesmo que ao longo dela essa identidade vá se transformando e adotando novos sentidos. Ela serve como uma referência que cria uma sensação de estabilidade necessária para a tomada de decisão. Já os eventos ocorridos em Bhopal - um vazamento de 40 toneladas de gases tóxicos na fábrica de pesticidas da empresa estadunidense Union Carbide, com mais 500 mil pessoas expostas aos gases (MAITLIS; SONENSHEIN, 2010) ilustram os possíveis efeitos negativos que algumas identidades podem provocar. Na ocasião, o compromisso assumido com o sigilo pelos membros da organização gerou relutância em soar um alarme durante o vazamento de gases tóxicos, o que aumentou as proporções do desastre. 
Outro exemplo em que as identidades impactaram negativamente na mitigação da crise foi o caso analisado por Guimarães e Alves (2014). Os autores estudaram sensemaking em resposta a um desastre ambiental de base organizacional no Brasil - causado pelas ações da Shell ao produzir, armazenar e despejar produtos químicos tóxicos em Vila Carioca, São Paulo. A análise procurou compreender o sensemaking por meio das narrativas de gestores públicos, corporações e sociedade civil. Assim, Guimarães e Alves (2014) explicaram, por meio da criação de uma estrutura que integra o sensemaking, a análise narrativa e a metáfora do teatro, como os significados foram selecionados, legitimados e institucionalizados. Nesse sentido, cada ator adotou comportamentos que eram modificados à medida que a crise se desenrolava, elaborando novas narrativas, desde que essas não alterassem suas identidades primordiais.

Finalmente, Poegler e Bisel (2013) analisaram as conexões entre o IdO e a mobilização de mecanismos comunicativos de defesa contra acusações de ações organizacionais antiéticas, isto é, eles analisaram o papel moderador da identificação em relação às respostas. Esses autores atribuíram a redução da aprendizagem moral nas organizações, em parte, à alta identificação (POEGLER; BISEL, 2013). Vale ressaltar que apesar das diversas pesquisas sobre respostas a alegações de má conduta organizacional, estas se concentraram em análises no nível organizacional e institucional, havendo considerável escassez sobre as respostas de indivíduos, e particularmente empregados, acerca das crises éticas organizacionais.

\subsubsection{As Reações Defensivas}

Situações de quebra de sentido, como as mencionadas anteriormente, são geradoras de ambiguidades, o que pode levar as pessoas a engajarem em mecanismos cognitivos que permitam elaborar essas inconsistências. A maior parte dos comportamentos dos membros, dentro e fora das organizações, tem motivações não conscientes, mas por mais incoerente que o comportamento humano possa parecer, existe nele uma lógica subjacente (VRIES; BALAZS, 2010). Comportamentos incoerentes são mantidos por meio de reações defensivas, isto é, por lógicas que os justificam. O sentido desse comportamento pode ser entendido por meio da determinação de sua origem e de informações contextuais. Apoiados nos estudos da psicologia, mais particularmente da psicanálise, Vries e Balazs (2010) descrevem algumas das ações defensivas usualmente empregadas. 
Quadro 1. Reações Defensivas

\begin{tabular}{|l|l|}
\hline Divisão & $\begin{array}{l}\text { Engajar no pensamento nós - versus - eles. As pessoas veem os outros como } \\
\text { a favor delas ou contra elas; não há meio termo. }\end{array}$ \\
\hline Projeção & $\begin{array}{l}\text { Atribuir falsamente seus próprios sentimentos não reconhecidos aos } \\
\text { impulsos ou pensamentos aos outros. }\end{array}$ \\
\hline Negação & $\begin{array}{l}\text { Declinar em aceitar algum aspecto da realidade externa que são óbvios para } \\
\text { os outros. }\end{array}$ \\
\hline Deslocamento & $\begin{array}{l}\text { Redirecionar seus sentimentos para uma pessoa que é menos "perigosa" do } \\
\text { que a que a agressão realmente se destina. }\end{array}$ \\
\hline Racionalização & $\begin{array}{l}\text { Envolve a construção elaborada de explicações autossuficientes, mas } \\
\text { incorretas, para o próprio comportamento (e dos outros). }\end{array}$ \\
\hline
\end{tabular}

Fonte: Adaptado de Vries e Balazs (2010)

Particularmente quando a identidade pessoal é ameaçada, a ansiedade gerada em uma crise pode mobilizar o uso de mecanismos cognitivos compensatórios - i.e., o engajamento do indivíduo em mecanismos de defesa (CRAMER, 1999). Petriglieri (2011) define a ameaça à identidade como a percepção de que uma experiência pode prejudicar os valores, sentidos ou mesmo a declaração da identidade de um indivíduo. Assim, ela também propôs algumas reações defensivas que as pessoas costumam utilizar a fim de salvaguardar suas identidades.

Quadro 2. Reações Defensivas da Identidade

\begin{tabular}{|l|l|}
\hline Derrocação & $\begin{array}{l}\text { Critica-se ou denuncia-se o atacante à sua identidade, a fim de desacreditá- } \\
\text { lo. }\end{array}$ \\
\hline $\begin{array}{l}\text { Distinção } \\
\text { Positiva }\end{array}$ & $\begin{array}{l}\text { É a resposta mais proativa. Usam-se virtudes da identidade como } \\
\text { argumento para mudar a opinião de quem a ataca. }\end{array}$ \\
\hline $\begin{array}{l}\text { Ocultação/ } \\
\text { Dissimulação }\end{array}$ & $\begin{array}{l}\text { Tenta-se atenuar ou esconder a identidade ameaçada de forma a dissuadir o } \\
\text { comportamento ameaçador. Ao fingir que não possui a identidade } \\
\text { mais utilizada quando a importância da identidade ameaçada é baixa, } \\
\text { diferentemente da distinção positiva. }\end{array}$ \\
\hline
\end{tabular}

Fonte: Adaptado de Petriglieri (2011)

Quando uma crise ou ameaça torna ambígua a IO, e diante das incertezas por ela provocadas, as pessoas procuram por novos sentidos ou fazem releituras de antigos sentidos, de forma acomodá-los à nova situação. Nesse último caso, elas podem buscar justificativas para sua identidade e a de sua organização (MAITLIS; CHRISTIANSON, 2014). Como os mecanismos de defesa são recursos cognitivos que podem surgir nessas situações, este estudo parte da premissa de que, por serem eventos provocadores de quebra de sentido, nas crises organizacionais os indivíduos tenderão a mobilizar mecanismos de defesa, e aplica esses mecanismos psicológicos como conceitos sensibilizantes na investigação. 


\subsection{Metodologia}

O Estudo 1 foi conduzido na empresa Vale SA após o desastre da cidade de Mariana. A antiga Companhia Vale do Rio Doce (CVRD) foi fundada em 1942 como uma empresa mineradora estatal brasileira (FGV CPDOC, 2009). Em maio de 1997, durante o Governo de Fernando Henrique Cardoso (FHC), sob protestos, a companhia foi privatizada (FGV CPDOC, 2009). A CVRD tornou-se a Vale S.A, atualmente, uma empresa transnacional que opera em mais de 30 países nos cinco continentes e está entre as maiores mineradoras globais (VALE SA, [s.d]). A empresa possui várias iniciativas de rememoração de sua trajetória, mesclando-a às memórias de suas comunidades circunjacentes e às transformações históricas nacionais (VALE, 2012).

A pesquisa de campo teve como foco as seguintes questões:

1) Como os empregados da Vale dão sentido ao desastre de Mariana?

2) Mecanismos de defesa são mobilizados por esses empregados nesse processo? Quais e em que circunstâncias?

Para responder a essas questões, optou-se por realizar uma investigação qualitativa, conduzida com base em entrevistas em profundidade (MASSARIK, 1991) com 10 empregados da Vale e 3 ex-empregados que estavam vinculados à empresa durante a crise decorrente do desastre de Mariana. As entrevistas foram realizadas no período de dezembro de 2017 a janeiro de 2018. A maioria dos entrevistados foi contatada via aplicativo Messenger da rede social Facebook. Utilizou-se a página no Facebook do sindicato Metabase de Mariana para identificar possíveis trabalhadores da Vale. Foram inicialmente contatados em torno de 105 empregados. As mensagens enviadas esclareciam os objetivos e procedimentos da pesquisa. Das 23 pessoas que retornaram a mensagem, nove concederam entrevistas, as demais se mostraram interessadas na pesquisa, porém, informaram que não gostariam de conceder entrevista, sem mencionar as suas razões para a negativa. Quatro entrevistados foram recrutados nas redes sociais da autora deste trabalho. É importante salientar que dentre os entrevistados nenhum pertence (ou pertencia) a unidade da Vale diretamente afetada pelo rompimento. Outra importante ressalva é que um dos entrevistados pediu que a entrevista fosse realizada por escrito (via aplicativo whatsapp). Foi garantido aos participantes o anonimato - os nomes utilizados neste artigo são fictícios. O Quadro 3 apresenta os 
perfis resumidos de todos os entrevistados. Os participantes estavam vinculados a unidades da Vale nos estados do Rio de Janeiro, Pará, Espírito Santo e Minas Gerais.

\begin{tabular}{|c|c|c|c|}
\hline \multicolumn{4}{|c|}{ Quadro 3 - Perfil dos Entrevistados } \\
\hline Nome & $\begin{array}{l}\text { Tempo de } \\
\text { empresa } \\
\text { (anos) }\end{array}$ & Último Cargo & $\begin{array}{c}\text { Vínculo } \\
\text { Empregatício com a } \\
\text { Vale }\end{array}$ \\
\hline Antônio & 32 & Supervisor de Operação & Empregado \\
\hline Bruno & 9 & Analista Sr. & Empregado \\
\hline Cláudio & 9 & Operador de equipamentos pesados & Empregado \\
\hline Elton & 12 & $\begin{array}{l}\text { Operador de equipamentos de } \\
\text { instalações II }\end{array}$ & Empregado \\
\hline João & 15 & $\begin{array}{l}\text { Supervisor de controle de processos } \\
\text { operacionais }\end{array}$ & Empregado \\
\hline Valentina & 15 & Técnica especializada de produção & $\begin{array}{c}\text { Ex-empregada } \\
\text { (desligamento a } \\
\text { pedido) }\end{array}$ \\
\hline Henrique & 7 & Maquinista de trem & Empregado \\
\hline Inácio & 6 & Analista de Informação Master & Empregado \\
\hline Flávio & 9 & Gerente de operação & Empregado \\
\hline Laís & 11 & Analista Master de navegação & $\begin{array}{c}\text { Ex-empregada } \\
\text { (demitida) }\end{array}$ \\
\hline Marcos & 11 & Mecânico & $\begin{array}{c}\text { Ex-empregado } \\
\text { (desligamento a } \\
\text { pedido) }\end{array}$ \\
\hline Nilson & 8 & Mecânico II & Empregado \\
\hline Olívia & 11 & Analista Master de Compras & Empregado \\
\hline
\end{tabular}

As entrevistas foram semiestruturadas, realizadas via ligação de Whatsapp e gravadas. Elas contaram com roteiro mínimo, cobrindo questões como "Como é a Vale? Como você se sente como empregado da Vale?", "Sobre o rompimento da barragem de Fundão em Mariana, como você se sentiu a respeito?", "Como seus colegas reagiram?”, “O que você pensa sobre o que aconteceu?’. Continuamos a abrir perguntas a partir dessas, para estimular os entrevistados a explorar e abordar diferentes dimensões de suas experiências e percepções, e para enriquecer as respostas com relatos sobre suas vivências pessoais (MACCRACKEN, 1988).

A partir das transcrições das entrevistas, os depoimentos foram analisados preliminarmente quanto ao seu conteúdo, buscando avaliar as reações elaboradas a respeito do desastre de Mariana. Primeiro, identificamos passagens particularmente 
relevantes para as questões de pesquisa e depois, selecionamos os enunciados com essas observações (MACCRACKEN, 1988). Conforme os temas foram identificados, os trechos relacionados às questões centrais da pesquisa foram agrupados. Finalmente, as reações defensivas ao desastre que emergiram dos estágios anteriores foram associadas em um conjunto consistente e parcimonioso de categorias confrontadas com o aporte teórico de Vries e Balazs (2010) e Petriglieri (2011). Uma nova categoria defensiva não referendada nesses estudos foi elabora a partir dessa análise. Os três ex-empregados da Vale (que ainda estavam na empresa quando ocorreu o desastre) não esboçaram reações que coincidissem com as categorias tomadas a priori, assim, suas falas foram consideradas e apresentadas separadamente. Por fim, um modelo que sintetiza as implicações do vínculo funcional, da intensidade da $\mathrm{IdO}$ e os mecanismos de defesa nas respostas dos empregados a alegações de má conduta organizacional foi proposto.

\subsection{Análise}

Tendo em vista as diferenças marcantes observadas nos relatos de empregados vinculados e os não vinculados à empresa, a análise apresenta separadamente os mecanismos de produção de sentido observados nos dois grupos.

\subsubsection{Trabalhadores Ainda Vinculados à Vale}

A identificação organizacional dos empregados com a empresa parece estar intrinsecamente implicada na produção de sentido no pós-crise. O Quadro 4 apresenta trechos das entrevistas que refletem a identificação dos entrevistados que se mantiveram vinculados (empregados) à Vale, de forma ilustrativa, e trechos das entrevistas que explicitam os sentidos que emergem em suas falas. Foram utilizados segmentos representativos das entrevistas para elucidar a análise e, por conseguinte, a categorização, quanto aos mecanismos mobilizados.

Entre empregados que manifestaram grande identificação, ou seja, forte assimilação do pertencimento à empresa ao seu autoconceito, o desastre de Mariana parece representar uma ameaça maior, isto é, provocar maior ambiguidade, em relação aos sentidos até então atribuídos a IO. E, assim, esses indivíduos engajaram em mais reações defensivas. Os empregados que demonstraram ter identificação mais intensa mobilizaram reações de distinção positiva, derrocação, negação, 
divisão, projeção, racionalização e vitimização (categoria elaborada a posteriori), enquanto os que manifestaram uma identificação menos intensa com a empresa apresentaram poucas reações defensivas - distinção positiva e ocultação. A análise detalhada das falas e sua correspondência com mecanismos de defesa está consolidada no Quadro 4.

Tomados em sua integridade, os relatos de alguns participantes permitem uma caracterização mais clara da intensidade da IdO e mecanismos de defesa acionados. Antônio, por exemplo, parece bastante identificado com a empresa: “[...] eu sou suspeito para falar. Tudo o que eu tenho, eu agradeço a Vale". Mais do que um vínculo afetivo, a fala de Antônio denota verdadeira reverência, ao colocar a importância dessa entidade em sua vida muito próxima da de Deus. Ao refletir sobre o desastre, Antônio engajou no pensamento "nós da mineração" versus "eles de fora da mineração", caracterizando a reação de divisão (VRIES; BALAZS, 2010). Ele diz que "não foi o fato [rompimento da barragem] a razão do rio ter morrido"; acredita que o rio já estava morto pelo esgoto que a população depositava nele. Assim, Antônio também apresenta a reação defensiva de negação (VRIES; BALAZS, 2010). Ademais, há uma crítica implícita ao juízo dos “de fora da mineração", que fica mais evidente ao longo de toda a entrevista, em um esforço de desacreditar suas opiniões. Esta sua reação caracteriza a derrocação (PETRIGLIERI, 2011). Além disso, Antônio conta de forma proativa uma das ações que ele realiza na empresa com vistas à preservação do meio ambiente, em um aparente esforço para enfatizar virtudes associadas à empresa. Por isso, também apresenta a distinção positiva (PETRIGLIERI, 2011).

Elton também apresenta identificação intensa, e diz: "Era um sonho meu e da minha família fazer parte dessa grande e maravilhosa empresa". Ele ressalta em seguida o forte sentimento de orgulho associado a esse pertencimento. Quando analisa o desastre, Elton é taxativo "todos nós funcionários tínhamos certeza concreta que a empresa mantinha o sistema de monitoramento com tecnologia de ponta monitorando as barragens", atribuindo seus próprios pensamentos aos outros, ou seja, manifestando a reação de projeção (VRIES; BALAZS, 2010). Com base nesse mesmo pensamento, sua reação também pode ser classificada como de negação (VRIES; BALAZS, 2010), já que ele não avalia que tenha havido falta de cuidado por parte da empresa. Ademais, ele usa as ações tomadas em decorrência do desastre, isto é, realizadas a posteriori, como investimentos em tecnologia para 
evitar acidentes, como elemento para analisar o desastre passado, caracterizando a reação de racionalização (VRIES; BALAZS, 2010). Por fim, somada a atitude de evocar virtudes da empresa com relação à preservação do ambiente à grande importância que atribui a sua identidade como empregado da Vale, Elton também manifesta a distinção positiva (PETRIGLIERI, 2011).

Nilson também tem uma intensa identificação: "Quando a gente veste aquela camisa, eu me sinto muito orgulhoso." Sua fala ressalta sua superação pessoal em relação às restrições sociais que vivenciava. Além do vínculo afetivo observado nos casos anteriores, as experiências que ele teve na empresa parecem ter um importante papel e fortalecer seu autoconceito, sua identidade. Ele também enfatiza aspectos positivos da empresa, porém, sem que isso seja usado como justificativa para o desastre. Ele coloca a Vale em um "mesmo nível de sofrimento" que os atingidos pelo desastre: "É meio triste, né. O que ela [Vale] passou para gente foi uma tristeza muito grande e uma perda drástica.". Com base em seu depoimento, observa-se uma nova categoria de mecanismo defensivo, a vitimização, quando considera a empresa como vítima do desastre pelo qual foi responsável.

Bruno, por outro lado, parece não ter uma identificação tão intensa. No entanto, quando questionado a respeito do desastre, ele alega se incomodar com comentários de pessoas de fora da organização, por isso sua identificação pode ser considerada ambivalente. Ele manifesta menos reações defensivas. Mesmo assim, diz acreditar que a empresa está cumprindo com sua responsabilidade na reparação do erro, engajando assim numa reação de distinção positiva (PETRIGLIERI, 2011). Ele adota uma postura não combativa em relação aos comentários negativos, de forma a dissuadir o comportamento ameaçador. Por esse motivo, a reação de Bruno também manifesta a ocultação (PETRIGLIERI, 2011).

Assim, quanto mais intensa a incorporação do pertencimento ao coletivo organizacional ao autoconceito do indivíduo e seu vínculo afetivo com a organização, maior parece ser a ameaça percebida (ambiguidades) e, por conseguinte, a necessidade de proteger o self. Isto porque a observação de mecanismos de defesa como via de produção de sentido emergiu de forma mais intensa e frequente entre aqueles com forte $\mathrm{IdO}$. 
Quadro 4. Identificação e Sentido via Reações Defensivas (Empregados Vinculados)

\begin{tabular}{|c|c|c|c|}
\hline \multicolumn{2}{|c|}{ Identificação com a Vale } & \multicolumn{2}{|r|}{ Sentidos via reação defensiva } \\
\hline \multirow{3}{*}{ Antônio } & \multirow{3}{*}{$\begin{array}{c}\text { "Assim, eu sou } \\
\text { suspeito para falar. } \\
\text { Tudo o que eu tenho, } \\
\text { eu agradeço a Vale." } \\
\text { "depois de Deus foi a } \\
\text { minha família e a } \\
\text { Vale, né" }\end{array}$} & Divisão & $\begin{array}{l}\text { "as pessoas que estão fora da mineração, eles } \\
\text { veem a gente como o vilão do meio ambiente, } \\
\text { o vilão de tudo". }\end{array}$ \\
\hline & & $\begin{array}{l}\text { Negação e } \\
\text { Derrocação }\end{array}$ & $\begin{array}{l}\text { "no fundo aquele rio ali o que jogava de esgoto } \\
\text { naquele rio [refere-se à população local], era } \\
\text { um absurdo também." "não foi o fato } \\
\text { [rompimento da barragem] do rio ter morrido". }\end{array}$ \\
\hline & & $\begin{array}{c}\text { Distinção } \\
\text { Positiva }\end{array}$ & $\begin{array}{l}\text { "A gente recupera tira de dentro da barragem, } \\
\text { para poder reutilizar o produto" "É um custo } \\
\text { benefício que não é nem tão viável } \\
\text { financeiramente, mas ecologicamente" "me } \\
\text { sinto até privilegiado de estar contribuindo com } \\
\text { esse fato". }\end{array}$ \\
\hline \multirow[t]{2}{*}{ Bruno } & \multirow{2}{*}{$\begin{array}{l}\text { “Aquela questão do } \\
\text { orgulho, orgulho } \\
\text { não. É porque eu } \\
\text { sou profissional e } \\
\text { amanhã ou depois } \\
\text { se surgir uma } \\
\text { oportunidade que } \\
\text { pague melhor ou } \\
\text { que venha me } \\
\text { proporcionar uma } \\
\text { melhor qualidade de } \\
\text { vida, eu sairia". }\end{array}$} & Ocultação & $\begin{array}{l}\text { "pô, dá até vergonha de dizer que trabalha na } \\
\text { Vale porque todo mundo agora crítica" “O } \\
\text { pessoal falava 'mas que coisa que a Vale fez, } \\
\text { hein? Que situação, hein?’Aí eu ficava meio } \\
\text { que naquela coisa, vou falar o que? Acho que é } \\
\text { algo que não tem defesa, né? É algo } \\
\text { indefensável” "lógico que era chato, né?" "mas } \\
\text { levava de boa" "Parece que você é o } \\
\text { responsável, né?" }\end{array}$ \\
\hline & & $\begin{array}{c}\text { Distinção } \\
\text { Positiva }\end{array}$ & $\begin{array}{l}\text { "a gente via que a empresa estava querendo } \\
\text { fazer de alguma forma porquê de um dia para o } \\
\text { outro o que vinha de nota fiscal de água, } \\
\text { compra de água lá para o Espírito Santo e } \\
\text { interior de Minas, era um volume muito } \\
\text { grande". }\end{array}$ \\
\hline \multirow{4}{*}{ Elton } & \multirow{4}{*}{$\begin{array}{l}\text { “Hoje também temos } \\
\text { uma empresa que } \\
\text { investe pesado em } \\
\text { gestão e isso faz de } \\
\text { nossa empresa uma } \\
\text { casa fora de casa. Eu } \\
\text { me sinto em casa } \\
\text { com tantos valores } \\
\text { atribuídos a mim } \\
\text { como profissional } \\
\text { através dos meus } \\
\text { gestores." "Era um } \\
\text { sonho meu e da } \\
\text { minha família fazer } \\
\text { parte dessa grande e } \\
\text { maravilhosa } \\
\text { empresa" "mais que } \\
\text { tudo isso também, } \\
\text { era um grande } \\
\text { orgulho". }\end{array}$} & Projeção & $\begin{array}{l}\text { "todos nós funcionários tínhamos certeza } \\
\text { concreta que nossa empresa mantinha o sistema } \\
\text { de monitoramento com tecnologia de ponta } \\
\text { monitorando as barragens". }\end{array}$ \\
\hline & & Negação & $\begin{array}{l}\text { "A imagem da empresa pra mim mudou } \\
\text { positivamente, pois ela assumiu todas as } \\
\text { responsabilidades, cumpriu e está ainda } \\
\text { cumprindo com as suas responsabilidades". }\end{array}$ \\
\hline & & Racionalização & $\begin{array}{l}\text { "[A Vale] investiu tanto que a tecnologia pra } \\
\text { evitar acidentes de mesma proporção que hoje } \\
\text { nossas minas e barragens são monitoradas por } \\
\text { satélite e drones } 24 \text { horas por dia". }\end{array}$ \\
\hline & & $\begin{array}{c}\text { Distinção } \\
\text { Positiva }\end{array}$ & $\begin{array}{l}\text { "Sabemos que a empresa nos valoriza acima de } \\
\text { qualquer objeto dela" "ela [a Vale] tem grande } \\
\text { respeito com o meio ambiente, fazendo suas } \\
\text { atividades mais garantindo subsistência para as } \\
\text { gerações futuras, empresa sustentável". }\end{array}$ \\
\hline Nilson & $\begin{array}{l}\text { "Quando a gente } \\
\text { veste aquela camisa, } \\
\text { eu me sinto muito } \\
\text { orgulhoso porque } \\
\text { para mim ingressar } \\
\text { na Vale... Eu iniciei } \\
\text { de [hesitou] de } \\
\text { baixo" "aí não tinha } \\
\text { como pagar os } \\
\end{array}$ & Vitimização* & $\begin{array}{l}\text { "É meio triste, né. O que ela [Vale] passou para } \\
\text { gente foi uma tristeza muito grande e uma } \\
\text { perda drástica." "e muita gente diz assim, } \\
\text { pessoas mudam depois dos erros" "Ela [Vale] } \\
\text { tratou das coisas com a maior cautela e } \\
\text { delicadeza" "acredito que ela soube sair". }\end{array}$ \\
\hline
\end{tabular}




\begin{tabular}{|c|c|l|l|}
\hline cursos que eu & \\
realmente queria" "E & & \\
na Vale não, ela & & \\
ajuda a gente, a se & & \\
capacitar mais e & & \\
melhor". & & \\
\hline
\end{tabular}

\subsubsection{Empregados Não Mais Vinculados à Vale}

O Quadro 5 é similar ao Quadro 4, no entanto, os empregados representados nele não mantiveram o vínculo com a Vale, ou seja, não são mais empregados da empresa. Isso parece ser relevante para o processo de significação. O primeiro ponto a observar é que eles não se esforçaram em resguardar a Vale de possível responsabilidade em relação ao desastre, não defenderam a IO. Mecanismos de defesa não foram mobilizados em suas análises.

É possível verificar durante toda a entrevista com Marcos sua insatisfação com a empresa. Ele narra uma série de eventos em que sua expectativa de receber um tratamento justo, foi quebrada. Inclusive, durante a entrevista, ele disse que se desligou em razão de sua crescente insatisfação com os comportamentos da Vale.

O relato de Laís é semelhante ao de Marcos, porém em intensidade bem menor. Ela não trabalha mais na Vale e deu sinais de que já não se identifica tanto com a empresa. Talvez, por essa razão, tenha se sentido livre para abordar a responsabilidade da Vale em relação ao desastre. Laís alega que foi demitida por ter se recusado a mudar de unidade (do Rio de Janeiro para Minas Gerais) em razão de uma reestruturação da empresa. Assim, nos dois casos, não foram observadas falas que remetessem aos mecanismos de defesa observados entre aqueles que mantiveram seu vínculo com a Vale.

A fala de Valentina também não se aproximou de nenhuma das categorias baseadas em Vries e Balazs (2010) e Petriglieri (2011). Apesar de sentir orgulho de ter pertencido a Vale, esse sentimento parece muito mais atrelado a sua superação pessoal, ao fato de como mulher ter, por seu próprio mérito, se destacado em um ambiente "masculinizado" (termo usado por Valentina). Contudo, as experiências que ela teve na empresa parecem ter impactado positivamente seu autoconceito, sua identidade. Com relação ao desastre, ela mostrou-se desapontada com a atitude da Vale, tanto em razão do acontecimento em si, como por não ter prestado informações aos empregados de forma transparente. Sua concepção da Vale como 
uma empresa que cuida de seus empregados mudou. Ademais, Valentina alega que pediu demissão porque sua jornada de trabalho não estava compatível com suas demandas pessoais. Ela alegou ser mãe solo de dois filhos, um deles que requer cuidados especiais.

De uma maneira geral, a quebra do vínculo com a empresa - processo em alguns casos mobilizado anteriormente por rupturas no contrato psicológico pessoaorganização (caso de Marcos) - parece impactar na produção de sentidos, na medida em que promove certo afastamento do self do coletivo organizacional. Em outras palavras, a IdO desses indivíduos já não era tão intensa. Os ex-empregados não apresentaram mecanismos de defesa ao dar sentido à situação crítica (o desastre de Mariana). No caso da Valentina, a experiência de superação parece ser um valor mais importante para o seu autoconceito do que a organização propriamente. Possivelmente, esses ex-empregados não vivenciam a mesma ameaça que os empregados ainda vinculados à empresa. 
Quadro 5. Identificação e Sentidos em reações defensivas (Ex-empregados - Não Vinculados)

\begin{tabular}{|c|c|c|}
\hline \multicolumn{2}{|r|}{ Identificação com a Vale } & $\begin{array}{l}\text { Sentidos via Análise Crítica } \\
\text { Independente }\end{array}$ \\
\hline Laís & $\begin{array}{c}\text { "Eu já tive muito orgulho de trabalhar } \\
\text { na Vale, de dizer que trabalhava na } \\
\text { Vale". }\end{array}$ & $\begin{array}{l}\text { "Começou uma onda grande de demissão". } \\
\text { "Ele [Novo CEO] começou com esse } \\
\text { discurso que era a gente em primeiro lugar, } \\
\text { o funcionário era o bem maior da } \\
\text { empresa... E aí quando de fato, ele } \\
\text { começou o discurso não era coerente com a } \\
\text { realidade. O que ficou visível com esse } \\
\text { problema de Mariana é que a Vale foi } \\
\text { conivente com a situação ou não fez todos } \\
\text { os controles que deveriam ter sidos feitos e } \\
\text { poderiam ter evitado este acidente". }\end{array}$ \\
\hline Marcos & $\begin{array}{l}\text { "Olha eu falar para você que gostava, } \\
\text { gostava muito, não gostava não!" }\end{array}$ & $\begin{array}{l}\text { “Aquelas piadinhas, né, 'Culpa sua! Você } \\
\text { só fica caçando dinheiro, caçando tirar } \\
\text { minério a qualquer custo! E matou muita } \\
\text { gente"” "Isso muitas pessoas falavam com a } \\
\text { gente na rua." "Ah muitas das vezes } \\
\text { deixava pra lá e falava que a gente trabalha } \\
\text { da melhor forma possível, mas às vezes } \\
\text { acontece um incidente... E só! Essas } \\
\text { explicaçõezinhas que a gente dá. Não tinha } \\
\text { muito argumento." "Ah mudou bem! } \\
\text { Porque a gente achava que funcionava bem } \\
\text { né, porque fala, fala, fala, fala, fala, fala, } \\
\text { mas na verdade, rompeu, fez o estrago que } \\
\text { fez!” "A visão deles fala segurança, mas na } \\
\text { realidade, eles priorizam produção. Eles } \\
\text { querem que você não [se] machuque para } \\
\text { não deixar de dar lucro". }\end{array}$ \\
\hline Valentina & $\begin{array}{l}\text { "Eles sentiam muito orgulho de mim } \\
\text { [família]." "Eu tinha orgulho de mim, } \\
\text { eu tinha orgulho da empresa em que } \\
\text { eu trabalhava." "algumas } \\
\text { [escavadeiras] de } 400 \text { toneladas." "Eu } \\
\text { fui a primeira mulher a operar essas } \\
\text { máquinas aqui em Carajás." "E o meu } \\
\text { instrutor fez um relatório lá dizendo } \\
\text { que eu não tinha perfil para aquilo e } \\
\text { eu me senti desafiada né" "Aí eu } \\
\text { pensei comigo, ele vai ver se eu tenho } \\
\text { ou não perfil [risos]. Eu vou aprender } \\
\text { e vou ser melhor! E com o tempo eu } \\
\text { realmente consegui." "Fui a primeira } \\
\text { e até hoje considerada a melhor } \\
\text { operadora lá na Mina. Até hoje sou } \\
\text { lembrada como a melhor operadora } \\
\text { da Mina" "aprendi dentro da empresa } \\
\text { é provar para mim e para as pessoas } \\
\text { que eu não sou limitada. Eu consigo } \\
\text { superar, consigo aprender". }\end{array}$ & $\begin{array}{l}\text { "Eu acho que a empresa não trabalhou o } \\
\text { psicológico dos funcionários porque } \\
\text { realmente foi algo muito forte e que tinha } \\
\text { muito a ver com a gente aqui." "Eles não } \\
\text { trabalharam mais profundamente } \\
\text { explicando mais, falando o que a empresa } \\
\text { estava fazendo para socorrer as vítimas, } \\
\text { para a cidade e tudo." "Fica aquele } \\
\text { sentimento de que você também é } \\
\text { vulnerável". }\end{array}$ \\
\hline
\end{tabular}

Assim, a Figura 2 sistematiza a dinâmica de sentido sobre eventos críticos provocados pela má conduta organizacional, enfatizando o papel dos vínculos, formal e identitário. Tanto o vínculo formal quanto o identitário parecem influenciar a mobilização de mecanismos de defesa para dar sentido aos eventos. E, 
em conjunto, esses vínculos reforçam ainda mais a ativação desses mecanismos. Ainda que o vínculo identitário em alguns casos seja menos intenso (como no de Bruno), ambos concorrem para a mobilização de mecanismos de defesa.

Figura 2 - O Papel dos Vínculos na Respostas dos Empregados às Crises Éticas

Dinâmicas de Sentido sobre Eventos Provocados pela Má Conduta Organizacional

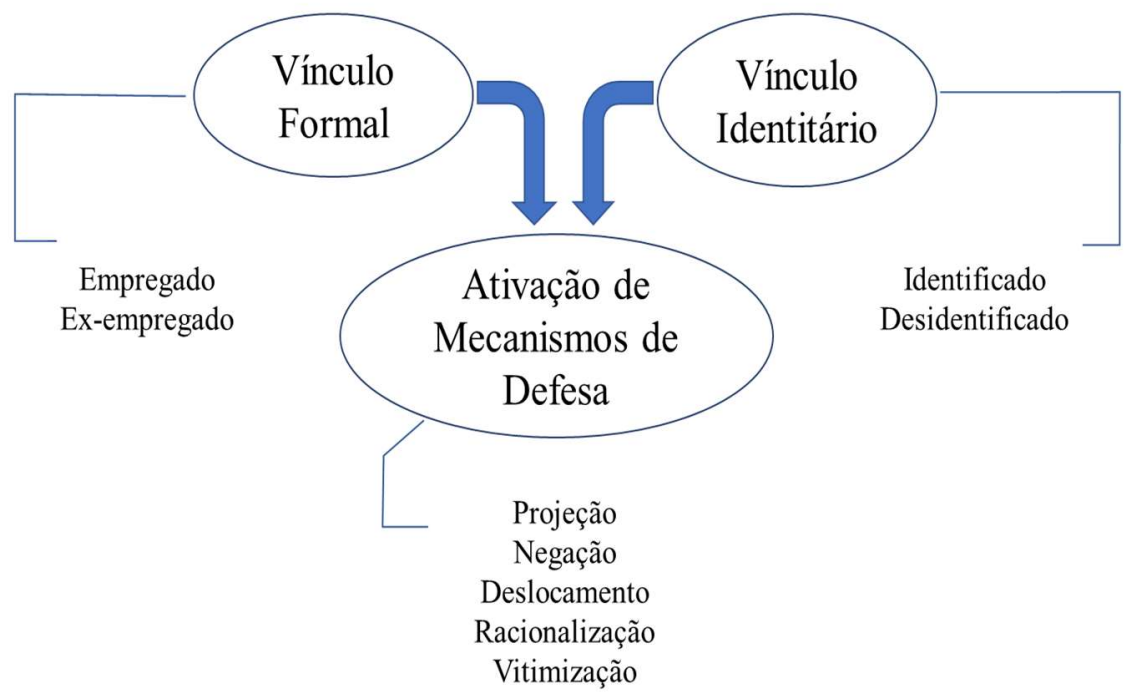

\subsection{Discussão dos resultados, achados e limitações}

Este estudo procurou compreender a resposta dos empregados da Vale S.A como tentativa de ressignificar o desastre de Mariana (Minas Gerais - 2015). O desastre estabeleceu uma crise, motivada por má conduta organizacional. Assim, os empregados que ainda estão vinculados à organização e se identificam com ela - ou seja, se definem, em parte, por meio de seu pertencimento ao coletivo organizacional - recorreram a mecanismos defesa da IO e, deste modo, procuraram salvaguardar o seu próprio self. Esses mecanismos, por sua vez, estão atrelados a mapas mentais individuais cuja ativação participa na produção de sentidos.

Os mecanismos mobilizados variaram em função do grau de identificação: quando a IdO é mais intensa, mais mecanismos de defesa foram mobilizados e com maior intensidade (distinção positiva, derrocação, negação, divisão, projeção, racionalização e vitimização); quando a IdO é menos intensa, menos mecanismos de defesa foram mobilizados e em menor intensidade (distinção positiva e ocultação). Os empregados que passaram pela ruptura no vínculo com a empresa e já não mais trabalhavam na Vale não mobilizaram mecanismos de defesa da IO. 
Deste modo, o vínculo com a empresa parece ser um determinante primário na produção de sentidos diante de crises que afetam diretamente a identidade da organizacional. Porém, a identificação do empregado com esse coletivo é um importante elemento adicional nesse processo, uma vez que quanto mais identificados com a empresa, mais intensos os mecanismos de defesa mobilizados. Isto se dá, provavelmente, em função da maior necessidade de salvaguardar o self da ameaça que a crise representa para o coletivo, uma vez que este é fonte de identidade social para o indivíduo. Quando a organização é menos relevante para o autoconceito, as ambiguidades provocadas por uma crise ética são atenuadas e, por conseguinte, a ameaça ao self.

As principais contribuições deste estudo residem, justamente, na compreensão das interconexões entre as variáveis relevantes na construção de sentido, com a proposição de um modelo analítico que organiza um caminho significação num contexto de crise. Observa-se, portanto, que as pessoas dão sentido ao que ocorre a sua volta com base em seus próprios modelos mentais e, sobretudo, nos seus vínculos. As imagens que são formadas nesse processo parecem associadas aos vínculos formais e identitários dos indivíduos, em função de sua necessidade de coerência cognitiva, individual e com a coletividade. Embora estudos anteriores tenham observado as respostas de gerentes nas crises éticas organizacionais (Hersel et al., 2019), tais pesquisas sobre respostas à má conduta organizacional se concentraram em análises no nível organizacional e institucional, e pouco foi explorado sobre as respostas de indivíduos, notadamente de empregados, nas crises éticas organizacionais.

Embora experiências de quebra de sentidos possam motivar as pessoas a repensar sentidos que já criaram e a questionar seus pressupostos (MAITLIS; CHRISTIANSON, 2014), as observações deste estudo reforçam o papel das identidades no enquadramento de eventos de má conduta empresarial vivenciados nas organizações (MAITLIS; SONENSHEIN, 2010), e nas barreiras que a identificação pode provocar na própria produção de sentidos. Em particular, este estudo observa como os vínculos, formais e identitários, mobilizam reações defensivas mesmo quando indivíduos dão sentido a eventos de má conduta corporativa de alta visibilidade e submetidos ao escrutínio público nas crises éticas organizacionais (Figura 2). Esses resultados ajudam a esclarecer por que esses 
mecanismos oferecem barreiras à aprendizagem nas organizações (POEGLER; BISEL, 2013).

As principais limitação deste estudo estão no fato dele ser centrado na Vale SA, que é uma proprietária da SAMARCO (uma joint venture de propriedade da Vale SA, brasileira, e da BHP Billiton, australiana) e, portanto, estava envolvida indiretamente na operação que causou o desastre. Além disso, não foi abordado nenhum empregado da localidade onde ocorreu o desastre, a barragem de Fundão em Mariana. A escolha pela inserção na Vale ocorreu em razão do lugar que a empresa tem no simbolismo nacional. E, o fato de não ter sido entrevistado nenhum empregado lotado na barragem de fundão ocorreu pela abstenção desses empregados, que não retornaram as tentativas de contato.

Ademais, no processo de recrutamento de participantes desse estudo, não foram encontrados empregados desvinculados da empresa que apresentassem forte identificação organizacional, no entanto, é possível que esse grupo exista, e que a força da identificação com tal coletivo para o ex-membro provoque a produção de sentidos via reações defensivas. No entanto, essa possibilidade permanece especulativa, uma vez que tal condição não se configurou neste estudo. Estudos futuros também devem explorar se o tipo de quebra de vínculo - voluntário ou involuntário - tem papel relevante nesse processo, e como a quebra se relaciona com a própria identificação e com os mecanismos de produção de sentido. Ainda, ressalta-se como possível que a produção de sentidos sem a mobilização de mecanismos de defesa da IO ocorram mesmo quando o empregado permanece vinculado à empresa, embora esse caso também não tenha sido observado neste estudo. Possivelmente mais raros, esses casos devem ser objeto de estudos futuros, tendo em vista seu potencial para transformar as práticas organizacionais e prevenir desvios corporativos. 


\section{Estudo 2 - Como as Lideranças Dão Sentido às Crises Éticas Organizacionais}

\subsection{Introdução}

Apesar das crises organizacionais envolverem diretamente suas lideranças, por vezes inclusive como protagonistas dos eventos desencadeadores, pouco se sabe sobre como aqueles responsáveis pela continuidade da gestão no pós-crise são por ela afetados e como reagem a esses acontecimentos. Como as lideranças enfrentam esses eventos e como reagem a essas crises?

Tendo em vista as interfaces entre liderança, identidade e sentido nas ações organizativas (LORD; GATTI; CHUI, 2016; FAIRHURST; GRANT, 2010; UHLBIEN, 2006), o contexto das crises éticas nas empresas constitui um terreno fértil para aprofundar o conhecimento sobre tais dinâmicas. Na literatura, os temas liderança e sentido tendem a ser tratados separadamente e poucos estudos teorizam sobre suas interconexões (WEICK, 1995; GIOIA; CHITTIPEDDI, 1991). Além disso, embora pesquisadores tenham investigado as respostas institucionais a acusações de conduta antiética (JOSHI; MCKENDALL, 2018) e as reações dos empregados a acusações de ações antiéticas pelas empresas (PLOEGER; BISEL, 2013), não foram identificados na literatura estudos que analisem o processo de enfrentamento das crises éticas pelas lideranças, nem as interações comunicativas das lideranças para dar sentido a tais eventos no pós-crise.

O estudo parte do pressuposto de que as respostas das lideranças às crises não envolvem processos completamente racionais, mas possivelmente se interconectam às necessidades básicas dos indivíduos de sustentar uma construção positiva do self (ASHFORTH; HARRISON; CORLEY, 2008). Dessa forma, a pesquisa se baseia na análise de conteúdo, para a geração de um quadro conceitual que demonstra o processo de sensemaking das lideranças em resposta às crises organizacionais provocadas pela má conduta das empresas, descrevendo (1) a Estratégia de Sensegiving da Liderança Executiva, com foco nos enquadramentos e narrativas, (2) o processo de enfrentamento das crises éticas organizacionais, com foco nos pensamentos e sentimentos das lideranças intermediárias, e (3) o processo de Sensemaking das Lideranças. A análise se baseou em dados obtidos através de entrevistas em profundidade conduzidas com líderes de nível intermediário 
(gerentes gerais, gerentes e coordenadores) e no conteúdo de 33 vídeos institucionais protagonizados por líderes de nível executivo (gerentes executivos) da Petrobras, após a crise associada ao escândalo de corrupção na estatal.

\subsection{Referencial Teórico}

\subsubsection{Crises e seu Impacto na Identidade Organizacional}

De acordo com Albert, Ashforth e Dutton (2000), toda entidade precisa ter uma noção de quem ou do que é - a identidade de uma empresa define aquela organização, e se articula como resposta à pergunta "Quem somos nós?". O conceito de identidade organizacional é considerado pelos autores um "construto raiz", pois permeia o debate sobre diversos fenômenos organizacionais associados à estratégia, ao desenvolvimento e à socialização nas empresas. Ela é orientada por uma visão de mundo em algum grau forjada pelos membros da organização, e que ao mesmo tempo estabelece uma forma de ser, fazer e interagir naquela coletividade (MACHADO-DA-SILVA; NOGUEIRA, 2001).

Por outro lado, a identificação organizacional (IdO) diz respeito ao grau em que a IO é um elemento constitutivo da identidade de um indivíduo, isto é, o quanto a sua autodefinição (“Quem sou eu?") é constituída por elementos associados àquela organização enquanto grupo social. A identificação organizacional também está relacionada ao valor/afeto que o indivíduo atribui a esta parte de sua autodefinição (ASHFORTH; HARRISON; CORLEY, 2008). Quando um indivíduo se define, mesmo que parcialmente, em função da identidade organizacional, isso dá sentido à sua existência e um sentimento de conexão. As teorias sobre identidade e identificação organizacional discutem as raízes sociais mais profundas de motivações e emoções humanas, que explicam ações (e omissões) coletivas (ALBERT; ASHFORTH; DUTTON, 2000).

Além disso, o sensemaking - processo pelo qual as pessoas significam o que ocorre a sua volta, com base em seus modelos mentais individuais e através da influência dos elementos e agentes do contexto nos quais estão inseridas (WEICK, $1995)$ - está fortemente atrelado a IO. Desta forma, crises organizacionais podem provocar questionamentos, podendo, inclusive, criar ambiguidades que ameaçam as qualidades atribuídas à IO (EBERLE; CASALI, 2012). E, isso é desconfortável tanto no nível individual quanto no nível organizacional, fato esse que compele os 
indivíduos a obliterar a ambiguidade na IO, ou seja, desencadeia o processo de sensemaking para ressignificá-la (CORLEY; GIOIA, 2004).

Nesse sentido, Joshi e MacKendall (2018) analisam os tipos de respostas a ameaças decorrentes de crises que afetam a IO, porém em nível institucional. Eles propõem um modelo que relaciona as respostas ao objeto da ameaça. Se a ameaça diz respeito à identidade primária - relacionada à razão de existir da empresa e sua missão - mais respostas são mobilizadas e com maior intensidade; se a ameaça diz respeito à identidade secundária - valores, modos de ser e fazer - menos respostas são acionadas e com menor intensidade.

\subsubsection{Liderança e Sensemaking no Pós-Crise: Fraturas na Visão de Mundo e Perdas}

Embora nem toda crise organizacional necessariamente implique a identidade de uma empresa, como visto anteriormente, estudos indicam que as crises que afetam diretamente a existência ou a razão de ser de uma organização impactam mais fortemente a IO e provocam reações institucionais mais intensas (JOSHI; MCKENDALL, 2018). Tendo em vista que uma crise é um evento repentino, não planejado, que causa intensa mobilização em uma empresa e desencadeia sentimentos de medo e ameaça entre seus membros, crises organizacionais podem ser definidas como um "evento traumático" (PEARSON; ROUX-DUFORT; CLAIR, 2007).

A literatura sobre eventos traumáticos oferece conceitos sensibilizantes relevantes neste estudo. O trauma pode ser definido como um "ataque ao eu" (HARVEY, 2002) e perdas traumáticas são descritas como abalos "sísmicos" na visão de mundo de uma pessoa ou no self (TEDESCHI; CALHOUN, 1995) que podem provocar fraturas em suas suposições centrais, seus ideais e sua autocompreensão, e que, frequentemente, roubam os indivíduos de algum aspecto essencial que antes dava sentido e propósito às suas ações (DAVIS; WOHL; VERBERG, 2007). Um evento traumático é aquele que ocorre fora da faixa de experiências ou expectativas normais da maioria das pessoas (WALSH; BARTUNEK, 2012). Uma perda traumática não se limita a eventos extremos como a morte de um membro da família, mas envolve qualquer perda que afete o senso de segurança dos indivíduos, ou que abale as suposições de indivíduos sobre como 
o mundo deve funcionar, provocando o sentimento de perda de sentido, perda de controle, impotência e angústia (KAUFFMAN, 2002).

Alguns pesquisadores (ASHFORTH; HARRISON; CORLEY, 2008; MAITLIS; CHRISTIANSON, 2014) afirmam que quando as organizações falham, elas deixam seus membros vulneráveis, o que pode impactar seu comprometimento e identificação com a organização. Esta "falha" pode ser reparada enquanto a organização existir. No entanto, há situações em que a organização, literal ou subjetivamente desaparece, em outras palavras, em que ocorre a morte organizacional (HARRIS; SUNTTON, 1986; WALSH; BARTUNEK, 2012). Kahn e Liefooghe, (2013) abordam os casos de incorporações, quando parte dos membros de uma organização incorporada (adquirida ou minoritária em uma fusão) é assimilada à nova organização. Inspirados na pesquisa sobre pesar (iminência da perda) ou luto (após a perda) (KÜBLER-ROSS; KESSLER, 2005), Crosina e Pratt (2019) propuseram um modelo de luto organizacional, que retrata a forma como os empregados (em nível individual) respondem à perda de sua organização.

\subsubsection{Liderança e Sensegiving no Contexto de Crises Organizacionais}

Instauradas as crises, os líderes costumam se engajar em iniciativas de sensegiving - medidas de promoção de sensemaking coletivo, com vistas à construção de sentidos específicos, propositados, por meio de atos de persuasão e comunicação - de forma a promover uma renovada clareza sobre a identidade organizacional (LOGEMANN; CORNELISSEN; REBECCA, 2018; FIOL, 2002; CORLEY; GIOIA, 2004). Segundo Caughron e Mumford (2012, p.344) “o sensemaking ajuda um líder a tomar decisões e ações diretas, mas também prepara o terreno para a comunicação, coordenação e monitoramento do progresso dentro de uma determinada situação". Nesse contexto, em especial os líderes de nível estratégico, que costumam ter maior impacto no processo de sensemaking organizacional (GIOIA; CHITTIPEDDI, 1991), precisam primeiro dar sentido às circunstâncias (que são mutáveis) e também às ideias, normas e valores antigos e novos. Ou seja, eles precisam realizar sensemaking a partir do fluxo de impulsos com os quais são confrontados (DEGN, 2015). E, por meio desse processo, eles também situarão as premissas do sensegiving (e.g.: a construção de metas, a prática da gestão estratégica, a comunicação de uma visão ou plano). 
Todavia, o sensemaking não é um processo completamente racional; ele procura atender a necessidades básicas da identidade para os indivíduos, como o autocrescimento ou autoaperfeiçoamento (self-enhancement), que se relaciona com "fazer parte de algo maior", associado a um senso de auto-estima coletiva; a autoeficácia (self-efficacy), que se refere à definição e seleção de problemas que acreditam ser capazes de solucionar e; a autocoerência ou autoconsistência (selfconsistency) que é a manutenção de um senso de identidade coerente e único - às vezes por meio do destaque de diferenças em relação ao outro (ASHFORTH; HARRISON; CORLEY, 2008; DEGN, 2015). De acordo com Degn (2015, p.903904), “essas três necessidades de identidade enquadram como os sinais são selecionados, pois elas enviesam a atenção para sinais que fortalecem os sentimentos de autoimagem positiva, competência e continuidade". Assim, essas necessidades associadas a uma construção positiva de self (identidade individual ${ }^{i}$ ) interferem no sensemaking, e por consequência, no sensegiving. Além disso, os gerentes de alto nível precisam responder por um lado à pressão externa de novas demandas de gestão estratégica, responsabilização e responsividade, e por outro, à pressão interna por legitimidade (DEGN, 2015) da identidade organizacional, que envolve as necessidades básicas mencionadas, porém no nível do coletivo.

Sobre como os principais sensemakers (líderes estratégicos) operacionalizam seu processo de sensegiving, Logemann, Rebecca e Cornelissen (2018) exploram o uso combinado de duas formas lingüísticas, o enquadramento e as narrativas. $\mathrm{O}$ primeiro "[...] envolve o uso sistemático de um conjunto de palavras-chave, frases de efeito, metáforas e expressões idiomáticas para fornecer um quadro interpretativo de referência para uma mudança [...]" (LOGEMANN; CORNELISSEN; REBECCA, 2018, p. 2-3). O que, muitas vezes, pode estar em consonância com os registros culturais de compreensão dos seguidores - crenças, valores e normas estabelecidas, por exemplo - tornando as coisas familiares, além de auferir legitimidade ao discurso, fortalecendo-o. Já as narrativas são construções discursivas que apresentam um enredo com atores e ações que passam do passado para o presente e precedem um futuro desejado - elas acontecem em um tempo e espaço delimitados, o que cria um senso de direção, de continuidade (LOGEMANN; CORNELISSEN; REBECCA, 2018). Ademais, as narrativas motivam e racionalizam as ações, por meio do seu sequenciamento. 
Quanto aos objetivos de senseginving dos líderes estratégicos, eles podem ser divididos em três categorias (DEGN, 2015), a saber: i) os “objetivos estratégicos externalizados" (externalized strategic goals) que procuram responder a pressões externas e a buscar legitimidade para as práticas de gestão por meio da incorporação das ideias percebidas como relevantes para esse público. Nesse sentido, elas são descritas, em regra, como "naturalmente necessárias para a sociedade em geral" e “obviamente razoáveis" (DEGN, 2015, p.908). Ademais, tais objetivos são despersonalizados, quer dizer, não são objetivos pessoais; ii) os "objetivos estratégicos personalizados" (personalized strategic goal) que estão ligadas a uma percepção de força e realização pessoal (autoeficácia) é a ideia de coisas que "fazem a diferença" e; iii) os "objetivos operacionais" (operational goals) que são voltados para o fortalecimento das estruturas e operações da organização, descritas frequentemente, como "limpar a bagunça" ou "ordenar as coisas" (DEGN, 2015, p. 909). Esses últimos estão ligados ao reforço da auto-eficácia e auto-aprimoramento, isto é, voltam-se para o público interno, mas também reverberam as ideias promulgadas pelo público externo.

Dada a importância da atuação das lideranças, em especial de nível estratégico, para orientar o sensemaking durante crises provocadas pela má conduta de uma organização, este estudo analisa como as lideranças de uma empresa vivenciam as quebras de sentido provocadas por esse tipo de crise organizacional e como as lideranças estratégicas da empresa atuam sobre o processo de sensemaking e qual o impacto da sua atuação.

\subsection{Metodologia}

A Petróleo Brasileiro S.A, conhecida como Petrobras, é uma sociedade de economia mista criada em 03 de outubro de 1953, durante o segundo governo de Vargas (1951 - 1954), seguindo as diretrizes nacional-desenvolvimentistas de seu projeto econômico (MARTINS, 2015). A Petrobras é a maior empresa brasileira de acordo com parâmetros econômico-financeiros, patrimônio líquido, ativo fixo operacional, faturamento, lucro líquido, número de empregados e etc (FGV CPDOC, [s.d]). A Petrobras participa ativamente na sua própria construção como símbolo nacional. (PETROBRAS, [2013]). Ela faz parte do panteão de símbolos nacionais brasileiros, por ser considerada parte da história do desenvolvimento do 
país e um tipo de patrimônio nacional. O Estudo 2 foi conduzido com as lideranças intermediárias da empresa, após a crise ética deflagrada pela operação lava-jato, e através da análise do conteúdo de vídeos institucionais produzidos por lideranças estratégias em referência ao mesmo evento.

\subsubsection{Entrevistas: Procedimento e Participantes}

Foram realizadas 10 entrevistas com empregados que desempenharam funções de liderança na Petrobras dentro do período de 2014 (início da Operação Lava-Jato) até os dias atuais. Os entrevistados foram contatados via aplicativo Linkedln. Todas as entrevistas foram semiestruturadas e contaram com roteiro mínimo. As entrevistas foram realizadas via ligação de Whatsapp e foram gravadas.

A seleção de participantes teve como critério a atuação em cargos de liderança. Possivelmente, em função do desequilíbrio na proporção de homens e mulheres nos níveis estratégico e tático da empresa, todos os participantes neste estudo são homens. O tempo na empresa variou de 6 a 33 anos. Embora a autora desta pesquisa tenha informações detalhadas sobre os cargos específicos ocupados pelos participantes ao longo de suas carreiras na empresa, optou-se por omitir a unidade de alocação e o cargo específico, a fim de assegurar o anonimato dos participantes. Os nomes utilizados para identificar os participantes neste estudo são fictícios. Embora a maioria dos líderes entrevistados estivesse atuando no nível tático no período da crise (gerentes, gerentes gerais e gerentes setoriais), três líderes atuavam no nível operacional (coordenadores). Esses profissionais atuam ou atuaram na Petrobras nas áreas de publicidade e mídia, finanças, operações, contratações, equipamentos e tubulação.

O Quadro 6 apresenta os perfis resumidos de todos os entrevistados.

Quadro 6 - Perfil dos Entrevistados

\begin{tabular}{|c|c|c|c|}
\hline Nome & Empresa & $\begin{array}{c}\text { Tempo na } \\
\text { empresa }\end{array}$ & $\begin{array}{c}\text { Nível da Liderança e Período de } \\
\text { Atuação }\end{array}$ \\
\hline Antônio & Petrobras & 33 & Tática (2015-2017) \\
\hline João & Petrobras & 17 & Tática (2014-Atual) \\
\hline Mathias & Petrobras & 7 & Tática (2012-2017) \\
\hline André & BR Distribuidora & 6 & Tática (2018-Atual) \\
\hline Julio & Petrobras & 32 & Tática (2014-2016) \\
\hline Clóvis & Petrobras & 11 & Tática (2017-Atual) \\
\hline
\end{tabular}




\begin{tabular}{|c|c|c|c|}
\hline Thiago & Petrobras & 30 & Operacional (2004-2014) \\
\hline Douglas & Petrobras & 13 & $\begin{array}{c}\text { Tática (2009-2017) } \\
\text { Estratégica (2018-atual) }\end{array}$ \\
\hline Vínícius & Petrobras & 12 & Operacional (2014 - 2016) \\
\hline Gustavo & Petrobras & 8 & Operacional (2006 - atual) \\
\hline
\end{tabular}

\subsubsection{Análise Documental}

Foram analisados 33 vídeos institucionais do canal Petrobras no site Youtube.

Os vídeos estavam organizados em campanhas intituladas "\#DaquiPraFrente", "Governança e Conformidade" e "Ações Anticorrupção" (\#DAQUIPRAFRENTE..., 2015; GOVERNANÇA..., 2017; AÇÕES..., 2018). Esses vídeos são protagonizados por empregados que se apresentaram em seus papéis de liderança e procuraram criar uma atmosfera de proximidade com as pessoas.

O Quadro 7 apresenta os perfis desses líderes (empregados da Petrobras) que protagonizaram os vídeos analisados na pesquisa. Apesar de nos vídeos eles se apresentarem com os seus nomes, optou-se aqui por referi-los por seus cargos, mantendo sua identidade preservada. Vale ressaltar ainda que nesses vídeos corporativos, os indivíduos são apresentados a partir dos papéis que representam dentro da organização, ou seja, como líderes executivos. Em outras palavras, apesar dos vídeos fazerem parecer que eles estão emitindo opiniões pessoais, na realidade, eles estão reproduzindo o discurso idealizado em campanhas planejadas.

Quadro 7 - Perfil dos Líderes Protagonistas

\begin{tabular}{|c|c|}
\hline Cargo & Campanha \\
\hline $\begin{array}{c}\text { Gerente Setorial de Contencioso Estratégico e } \\
\text { Arbitragem }\end{array}$ & \#DaquiPraFrente \\
\hline Gerente de Conformidade & \#DaquiPraFrente \\
\hline Diretor de Governança, Risco e Conformidade & \#DaquiPraFrente \\
\hline Gerente Executivo de Conformidade & \#DaquiPraFrente \\
\hline $\begin{array}{c}\text { Coordenador do programa de Capacitação } \\
\text { Tecnológica em Águas Profundas e Ultraprofundas }\end{array}$ & \#DaquiPraFrente \\
\hline $\begin{array}{c}\text { Coordenador do programa de Capacitação } \\
\text { Tecnológica em Águas Profundas e Ultraprofundas }\end{array}$ & \#DaquiPraFrente \\
\hline Advogado & \#DaquiPraFrente \\
\hline Administrador & Ações Anticorrupção \\
\hline Gerente Executivo do Jurídico & Ações Anticorrupção \\
\hline Diretor de Gestão, Risco e Conformidades & Governança e Conformidade \\
\hline
\end{tabular}




\subsubsection{Análise dos dados}

A codificação do corpus de análise - as transcrições dos depoimentos recolhidos por meio das entrevistas e dos vídeos institucionais - foi um processo dedutivo e indutivo. A análise envolveu categorias apriorísticas tomadas da literatura, como autocrescimento e autocoerencia (ASHFORTH; HARRISON; CORLEY, 2008), bem como novas categorias que emergiram dos dados e serão melhor descritas na próxima seção.

\subsection{Análise}

A primeira seção da análise tem por objetivo apresentar observações levantadas nas entrevistas acerca das duas necessidades para uma construção positiva do self que parecem ser atendidas por alguns dos elementos que compõem a identidade da Petrobras, conforme foi possível depreender dos depoimentos. A Figura 3 relaciona as unidades de análise retiradas dos depoimentos às necessidades do self identificadas: o autocrescimento e autocoerência. Essas mesmas necessidades do self são ameaçadas com os desdobramentos do escândalo de corrupção, como será visto nas próximas seções.

$\mathrm{O}$ autocrescimento relaciona-se ao entendimento comum nas falas dos depoentes de que o trabalho desenvolvido pelos empregados da Petrobras tem forte influência no desenvolvimento do país. Quer dizer, a construção positiva do self se manifesta no sentimento de orgulho advindo do pertencimento à empresa. E, esse orgulho deriva justamente da vinculação do self à identidade da empresa Petrobras, isto é, por estarem vinculados, a potência da IO é compartilhada com o self.

Já a autocoerência está relacionada ao sentimento de unicidade que emerge da percepção de que os empregados da Petrobras compartilham identidade e objetivos comuns. Essa unidade promove consistência, isto é, um senso de identidade estável ao indivíduo. Na empresa, a coerência individual parece se constituir em torno do senso de competência técnica de seus membros. O entendimento de que a empresa e o seus empregados possuem alta capacidade técnica também inspira orgulho. 
Figura 3 - Identidade da Petrobras

Unidades de Análise

- Eu trabalhando na Petrobras eu me sinto como se fosse empregado do país, do Brasil, eu trabalho pro bem do país e isso me orgulha (Júlio).

- A Petrobras, ela representa o Brasil (Administrador).

- Orgulho de ser petroleiro, orgulho de participar do crescimento do país de contribuir para o desenvolvimento do Brasil (Carlos).

- $[. .$.$] a Petrobras do meu tempo que a gente vestia a camisa,$ que os colegas eram como irmão, a gente se juntava em torno de um mesmo objetivo (Júlio).

- Uma capacidade técnica diferenciada, [...] a gente ganha prêmios desenvolvimento tecnológico no setor. [...] a qualidade técnica dos empregados [...] o concurso já busca selecionar e depois a empresa busca muito a qualificação dos empregados internamente (Clóvis).

- [Interlocutor - Qual [sic] o foco no desenvolvimento de tecnologias?] Essa é uma boa pergunta e motivo de muito orgulho para nós que trabalhamos na Petrobras e somos brasileiros [...] a Petrobras pode ser considerada uma referência tecnológica e nós acabamos de receber o prêmio [...] que é mais ou menos o Oscar da indústria [...] (Coordenador do Programa de Capacitação Tecnológica em Águas Profundas e Ultraprofundas)

É importante salientar que o autocrescimento e a autocoerência são reforçados nas campanhas publicitárias da Petrobras, o trecho do depoimento do coordenador do programa de capacitação tecnológica em águas profundas e ultraprofundas (Figura 3), retirado de um dos vídeos da campanha \#DaquiPraFrente (2015). Essas construções de sentido pretendidas pela liderança estratégica parecem encontrar assentimento entre os empregados, justamente por reforçarem uma construção positiva do self.

Nas próximas seções da análise, são apresentadas (1) as Estratégias de Sensegiving da Liderança Executiva, em torno dos temas Não existe caminho fácil, existe caminho certo e Petrobras, Vitima do Crime de Poucos; (2) o processo de Enfrentamento das Crises Éticas pelas lideranças intermediárias, que envolve três etapas, o Choque Traumático, a Fratura na Identidade Organizacional e Reparação Identitária, e (3) o Sensemaking das Lideranças, que sintetiza as dinâmicas e confluências entre os dois primeiros processos.
Necessidade do

Self

Autocrescimento

Autocoerência . 


\subsubsection{Estratégia de Sensegiving da Liderança Executiva}

O sensegiving da liderança executiva foi analisado por meio dos vídeos das campanhas supracitadas, além do depoimento de Douglas que faz parte da liderança executiva. Assim, cada vídeo da campanha \#DaquiPraFrente (2015) inicia com um cidadão (estudante, feirante, dona de casa e etc.) se apresentando (nome, ocupação, pretensões e etc.) realizando suas atividades cotidianas. Essa participação termina como uma pergunta direcionada à Petrobras e que norteará todo o restante do vídeo. Em seguida, o líder se apresenta (nome, tempo de empresa e cargo) em um ambiente organizacional e responde nominalmente à pergunta do cidadão.

Na campanha "Governança e Conformidade" (2017), os vídeos são protagonizados por pelo diretor da Diretoria de Governança e Conformidade. Nesses vídeos, o diretor, em um ambiente corporativo, parece conceder uma entrevista na forma de depoimento a um entrevistador implícito, quer dizer, que não aparece e nem tem suas perguntas reproduzidas. $\mathrm{O}$ diretor inicia o primeiro vídeo (nomeado "[nome do diretor]: Dois anos da Diretoria de Governança e Conformidade da Petrobras) da seguinte forma:

Muita coisa foi feita ao longo desses dois últimos anos, mas merecem alguns destaques que mostram como a empresa mudou, de dois anos prá cá. Inicialmente, é fundamental falar da mensagem do topo da alta administração [...].

O diretor de gestão, risco e conformidades segue destacando que esses profissionais da alta administração são independentes, competentes e comprometidos em defender os melhores interesses da empresa. Nos demais vídeos, ele fala sobre as mudanças, medidas de prevenção e combate a corrupção, ressaltando sempre a mensagem que a liderança deve passar

Nós também fizemos um amplo programa de treinamento [...] E, ele começa primeiro pela alta administração [...] para que as pessoas saibam e se motivem e se espelhem no exemplo da liderança. Isso é amplamente divulgado em campanhas extensas de comunicação que vêm sendo feitas (Vídeo "Treinamento e Mudança de Atitude para uma gestão transparente").

Apenas os três últimos vídeos, de um total de nove vídeos da campanha "Governança e Conformidade" (2017), não são com João, mas com consultores externos, possuem formato de entrevista convencional e procuram explicar alguns 
conceitos que foram tratados anteriormente por João como, por exemplo, Compliance e governança corporativa.

Já nos vídeos da campanha “Ações Anticorrupção" (2018) há apenas uma pessoa que se apresenta em um cargo de liderança de área diretamente relacionada às medidas de prevenção e combate a corrupção na Petrobras. Esse líder fala sobre a sua atuação nessas iniciativas, além de ressaltar a importância delas. Durante todo o vídeo, a câmera enfoca o rosto do líder, com closes pontuais nos olhos, boca e mãos.

Por outro lado, passando para análise do conteúdo dos vídeos, algumas narrativas (construções discursivas acerca da crise ética) e enquadramentos (frases de efeito que sintetizam e reforçam as narrativas) - categorias tomadas da literatura (LOGEMANN; CORNELISSEN; REBECCA, 2018) foram identificados como constituintes da Estratégia de Sensegiving da Liderança Executiva. Dois enquadramentos principais foram identificados Não Existe Caminho Fácil, Existe Caminho Certo e Petrobras: Vitima do Crime de Poucos. Tais enquadramentos bem como as narrativas que os compõem serão melhor descritos nas próximas seções.

\section{Não Existe Caminho Fácil. Existe Caminho Certo}

O processo de Sensegiving da Liderança Executiva iniciou-se antes da Operação Lava-Jato tornar-se pública, segundo Douglas "[A] área de riscos corporativos [...] criada à luz dos fatos que estavam começando a aparecer da LavaJato [2013]. [...] foi como resposta institucional da Petrobras pra crise que se avizinhava". No entanto, as iniciativas de sensegiving se intensificaram com o anúncio da criação da Diretoria de Gestão, Risco e Conformidades em novembro de 2014 (PETROBRAS, 2015), após a eclosão da crise e um período de negação.

A Campanha \#DaquiPraFrente (\#DAQUIPRAFRENTE..., 2015) apresenta uma série de medidas de combate e prevenção à corrupção - criação de uma força tarefa, uma comissão de investigações internas, da Diretoria de Governança Risco e Conformidade, do Programa Petrobras de Prevenção da Corrupção, além das auditorias internas, canal de denúncia e novos procedimentos para o reforço da segurança. Tais medidas são, principalmente, uma resposta aos stakeholders externos, como acionistas, além de configura-se como uma tentativa de reforçar a legitimidade da Petrobrás em meio ao escândalo de corrupção. 
A Figura 4 apresenta as narrativas que compõe o enquadramento Não Existe Caminho Fácil. Existe Caminho Certo. 
Figura 4 - Não Existe Caminho Fácil. Existe Caminho Certo. Unidades de Análise

- A Petrobras participa ativamente das investigações da Polícia Federal, do Ministério Público Federal e da Controladoria Geral da União. Foi criado [...] uma força tarefa dedicada exclusivamente a esses desdobramentos da operação Lava-Jato porque é claro, nós somos os principais interessados que essas investigações avancem rápido para que haja um ressarcimento adequado aos nossos cofres, a nossa imagem. Petrobras abriu diversas comissões de investigação internas. [...] também atua nas ações judiciais, essas ações buscam ressarcimentos em valores [...]. Toda a estrutura [...] hoje tem a intenção de colaborar nas investigações e se ver ressarcida [...] (Wagner)

- No bojo, dessa percepção [externa] existe uma mágoa [...] o problema de fraude e corrupção que foi associada com algo que não tem nada a ver conosco, mas foi a queda do preço do Brent no mercado internacional, com a queda dos royalties, com problemas no governo do Estado, tudo isso junto [...] o veículo de promoção social da região que era a Petrobras que injetava muito dinheiro na economia, botou o pé no freio, e isso impactou uma cadeia de profissionais (Douglas).

- [...] a empresa não controla o câmbio nem o preço do petróleo [...] é uma questão cíclica como já aconteceu em vários outros momentos na história do petróleo no mundo (Renata Szczerbacki).

- [...] A Petrobras pode ser considerada uma referência tecnológica e nós acabamos de receber o prêmio [...] que é mais ou menos um Oscar da indústria de óleo e gás no mundo. [...] e a Petrobras sendo detentora desse prêmio, é motivo de muito orgulho pra gente (Marcos)

- Não tem três caminhos, você tem um caminho e a diferença talvez esteja na magnitude, na intensidade com que você vai atuar em cada uma das ações desse caminho. [...] Como aconteceu tudo junto [fraudes e crise de preços $]$ potencializou o efeito, então essa solução econômico-financeira era uma só, [...] eu tenho que reduzir essa dívida, [...] botar o pé no freio dos investimentos, [...] recompor minha política de preços [...], lidar com órgãos de controle [...], buscar ressarcimento dos malfeitos [...] pra que eu tenha escrutínio da sociedade, ou seja, as contramedidas foram amargas, talvez inevitáveis (Douglas).

\section{Narrativa}

Nós somos os principais interessados que essas investigações avancem rápido.

Influência do preço do Petróleo nos negócios.

A Petrobras é uma referência tecnológica

A solução econômico-financeira era uma só. 
Essas duas frases em Não Existe Caminho Fácil. Existe Caminho Certo encerram (textualmente) todos os vídeos da campanha "Ações Anticorrupção" (2018) a fim de enfatizar que as medidas são consideradas desafiadoras, mas, também, impreteríveis.

Nesse sentido, a narrativa Nós somos os principais interessados que essas investigações avancem rápido é composta pelo anúncio de uma série de medidas com vistas a mitigar os efeitos negativos do escândalo de corrupção sobre a identidade da Petrobras, principalmente, para os stakeholders externos, em uma perspectiva de restauração da IO. Em outras palavras, é uma mensagem que reconhece a má conduta e demonstra que as medidas para reverter os danos e prevenir esse tipo de comportamento estão sendo tomadas. Ademais, essa narrativa cria um discurso de direção (BARRY; ELMES, 1997), além de colocar os empregados em um papel de agentes dessas iniciativas - que para eles, podem não ser completamente confortáveis, por envolver uma sucesssão de novos mecânismos de controle sobre o seu trabalho - procurando evitar com isso, possíveis resistências. Desta forma, os elementos dessa narrativa são os atores envolvidos - Petrobras, Ministério Público Federal, Polícia Federal e Controladoria Geral da União - suas ações e respectivos resultados no tempo (esses elementos são mais explorados durante as campanhas).

Em $A$ solução econômico-financeira era uma só é possível notar, novamente, a lógica de que não há alternativas às medidas que foram adotadas, agora ainda mais direcionado aos empregados, que mais sofreram com os ajustes econômicofinanceiros. Em outras palavras, essa narrativa tem como um de seus objetivos desencadear um senso de inevitabilidade das ações com vistas a contornar a crise, além de racionalizar as contramedidas, envolvendo e motivando os empregados a apoiá-las (LOGEMANN; CORNELISSEN; REBECCA, 2018).

Ademais, cabe ressaltar o esforço de esclarecer/afastar os problemas decorrentes do preço do barril de petróleo das ilicitudes ocorridas na empresa em Influência do preço do Petróleo nos negócios. Conforme apontado nos vídeos e no depoimento de Douglas, a queda no preço internacional do barril do petróleo - que prejudicou a economia do estado do Rio de Janeiro, bastante dependente dos royalties - coincidiu com o escândalo de corrupção, então as pessoas acabaram associando a mazela econômica do estado à corrupção na Petrobras. Por isso, o esforço das campanhas em separar o impacto da queda nos preços dos eventos 
ocorridos na empresa. Dito de outro modo, essa narrativa reposiciona os impactos do ambiente econômico separando-o dos desdobramentos da má conduta organizacional.

Além disso, a liderança, também, valoriza o potencial técnico da Petrobras em A Petrobras é uma referência tecnológica o que pode ser entendido como um reforço da autocoerência, já que a empresa sempre foi conhecida por sua alta capacidade técnica e assim permanece, a despeito da crise (conforme depoimentos). Essa foi uma narrativa bastante reproduzida nas falas dos empregados.

\section{Petrobras como Vítima do Crime de Poucos}

A segunda campanha foi a "Governança e Conformidade" - de março de 2017 a julho de 2017- em que o diretor de gestão, risco e conformidades, avaliou os dois anos de criação da respectiva diretoria (PETROBRAS, 2015). Ele reiterou o discurso abordado na campanha \#DaquiPraFrente (2015) continuando o esforço de racionalização das ações tomadas.

O enquadramento Petrobras como vítima dos crimes de poucos teve prevalência nos discursos dos entrevistados que parecem tê-lo julgado culturalmente ressonante e legitimo (KAPLAN, 2008). E, esse enquadramento é constituído pela narrativa Isso não representa a Petrobras, que parece ter tido efeito sobre o sensemaking organizacional. A Figura 5 apresenta uma unidade de análise que exemplifica a narrativa e, também, o enquadramento Petrobras como vítima dos crimes de poucos.

Figura 5 - Petrobras como Vítima dos Crimes de Poucos

\section{Unidades de Análise}

- $[\ldots]$ como já foi reconhecido pelo judiciário brasileiro, inclusive pelo próprio Supremo Tribunal Federal a Petrobras foi vítima dos crimes praticados e é uma vítima que age ativamente para recuperar a sua imagem, recuperar os valores em virtude dos acordos de delação premiada [...] (Gerente Executivo do Jurídico).

\section{Narrativa}

Isso não representa a Petrobras

Assim, há um esforço de fortalecer a autocoerência através na narrativa "isso não representa a Petrobras" promovida pela campanha Petrobras como vítima dos crimes de poucos. Noutras palavras, essa narrativa e enquadramento evocam a má conduta e influenciam os empregados de duas maneiras: destacando a mácula do 
malfeito da IO central e distinguindo os empregados em geral do grupo que cometeu os crimes. A Figura 6 consolida as observações do campo sobre a Estratégia de Sensegiving da Liderança Executiva. 
Figura 6 - Estratégia de Sensegiving da Liderança Executiva

Estratégia de Sensegiving da Liderança

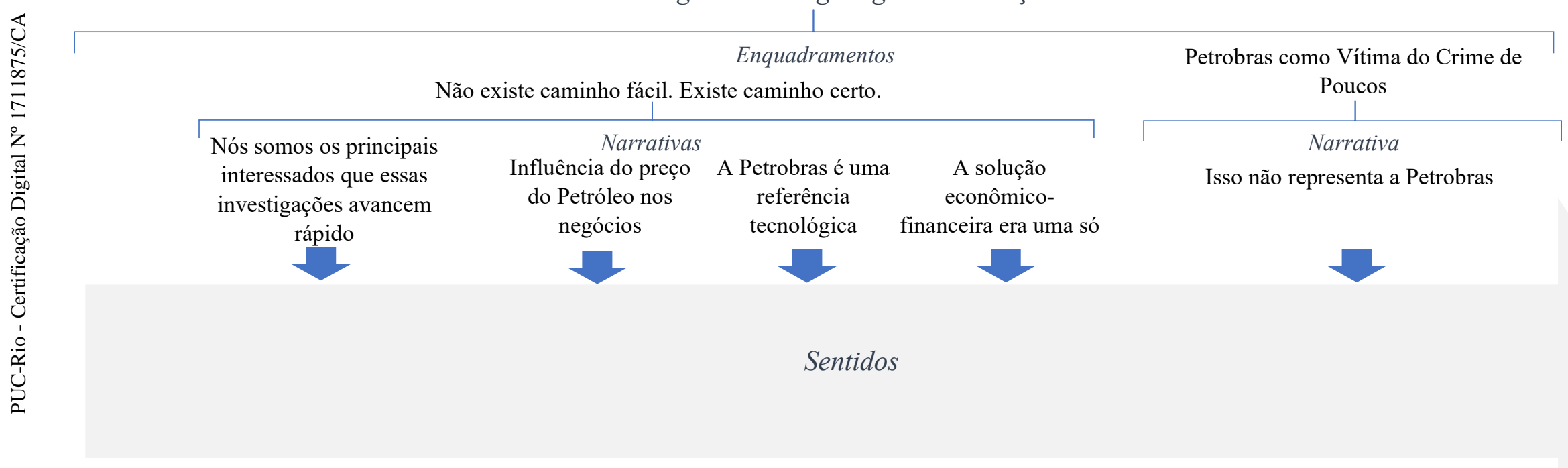


Na próxima seção é analisado o processo simultâneo de enfrentamento da crise ética organizacional pelas lideranças intermediárias, apresentando seus elementos processuais constitutivos, a saber: Choque Traumático, Fratura na Identidade Organizacional e a Reparação Identitária. Como detalhado a seguir, o enfrentamento ecoa, em grande medida, a Estratégia de Sensegiving da Liderança Executiva.

\subsubsection{O Enfrentamento das Crises Éticas pelas Lideranças Intermediárias}

\section{Choque Traumático}

Inicialmente, houve um esforço, por uma parte da liderança intermediária, de negar e/ou silenciar as notícias dos desdobramentos da Operação Lava-Jato e certa descrença no avançar da Operação. No entanto, essa postura ficou cada vez mais inviável diante dos avanços das ações da Polícia Federal e cobertura pelos meios de comunicação. Conforme a crise avançou, emergiram discrepâncias na identidade da Petrobras que mobilizaram diretamente as necessidades de autocrescimento e autocoerência dos empregados. Quer dizer, o orgulho dos empregados por fazerem parte de uma empresa tão relevante para o desenvolvimento econômico-social do país foi abalado pelo escândalo de corrupção, que também teve implicações em nível nacional. Assim, cria-se uma ambivalência: de um lado os atributos distintivos da identidade da Petrobras na percepção dos empregados, e do outro mácula na imagem provocada pelo evento perante a população em geral e a seus empregados, acompanhada pela decepção com os colegas envolvidos nos esquemas de corrupção.

A Figura 7 relaciona as unidades de análise destacadas dos depoimentos às respectivas categorias iniciais que compõem a categoria Choque Traumático. 
Figura 7 - Choque Traumático

Unidades de Análise

\section{Categorias \\ Iniciais}

- $\quad$ Em um [...] primeiríssimo momento [...] se tentou um discurso [...] de negativa. [...] na festa de final de ano [...] o diretor falou assim 'não vamos atentar para essas notícias que estão sendo veiculadas aí' [...] como que 'olha, isso aí é boato' [...] soou ridículo né? Todo mundo tava vendo [...] o cara sendo preso, polícia federal batendo e levando um monte de gente (Clóvis).

- Essa fase inicial a gente nem chegou a sentir nada porque a gente confiava muito no poder do PT [Partido dos trabalhadores] e que seria tudo abafado como no Brasil terminava tudo em pizza, né? (Thiago)

- A primeira sensação foi choque pelo nível onde aconteciam as irregularidades e como as coisas foram acontecendo e pelo volume (Júlio).

- Nós sofremos um misto de sentimento, primeiro foi uma surpresa, [..] você tinha pessoas que eram funcionários de carreira, reconhecidos por sua competência $[\ldots]$ com conhecimento muito grande da empresa [...] agir em causa própria. Isto foi uma surpresa prá muita gente, ninguém achava que no bojo daquelas escolhas [...] haveria, má fé [...] inclusive, indivíduos historicamente atrelados a empresa. Então o primeiro sentimento foi de surpresa com um misto de decepção. Você ver pessoas com história de vida na empresa, agirem como bandidos (Douglas).

- $\quad[. .$.$] minha equipe [...] é uma área [...] de auditoria interna [...]$ tinha que ter combatido tudo que aconteceu, passa assim, um pouco de vergonha $[\ldots]$ (André).

O Choque Traumático é caracterizado por sentimentos como negação e descrença, e inclui uma resposta inicial defensiva para proteger o self das ameaças provocadas pelo evento traumático ao abalar necessidades básicas de autocoerência ao autocrescimento. Depois vêm o "choque" e a "surpresa com um misto de decepção" pela amplitude da má conduta organizacional, que não se apresentou como um caso isolado, como os depoentes acreditavam incialmente, e que a todo momento procuraram distinguir dos empregados indicados por políticos ou por pessoas associadas a políticos. Ao contrário, o malfeito se caracterizou como algo sistêmico, envolvendo inclusive empregados de carreira. Dada a amplitude do evento, o nível de ameaça à identidade da Petrobras se assevera, e consequentemente também, ao self dos indivíduos a ela associados. Admissão da má conduta é o desenlace dessa fase do processo, nas qual os empregados se engajaram quando não era mais possível negar a realidade através de narrativas 
plausíveis e gravidade da má conduta se revelou por inteiro, impactando elementos da identidade da Petrobras fortemente associados à autocoerência de seus membros. Vale 
ressaltar que o desenlace de admissão da má conduta entre os membros possivelmente foi influenciado pelo sensegiving da alta gestão na campanha "Não existe caminha fácil. Existe caminho certo", que admite a má conduta, ao invés de negá-la.

\section{Fratura na Identidade Organizacional}

Esse processo enseja o sentimento de perda em relação a identidade da Petrobras vivenciado pelos membros da organização, em razão da mácula causada pelo julgamento negativo da sociedade, e que abala as necessidades básicas de autocrescimento e autocoerência. A vivência da Fratura na Identidade Organizacional é caracterizada por sentimentos como raiva e indignação, quando o escândalo se torna uma maior Ameaça ao Self, e a identidade dos "petroleiros" é pessoalmente maculada pelo evento, ao serem tratados de maneira generalizada como corruptos. Ademais, as medidas de combate e prevenção contra a corrupção são vistas com desconfiança o que leva a um sentimento de desesperança, além da mágoa decorrente do tratamento dado aos empregados que não estavam envolvidos com a má conduta.

A Figura 8 relaciona as unidades de análises destacadas dos depoimentos às categorias iniciais que compõem Fratura na Identidade Organizacional. 
Figura 8 - Fratura na Identidade Organizacional

\section{Unidades de análise}

- [...] existe a Petrobras do meu tempo que a gente vestia a camisa, que os colegas eram como irmão, a gente se juntava em torno de um mesmo objetivo. Hoje a Petrobras está destrocada! [mudou subitamente o tom da voz]. Muita gente trabalhando contra, não existe mais aquela [...] sintonia de todos trabalhando pelo mesmo objetivo, hoje as pessoas trabalham cada um pra salvar $o$ seu, mais egoísmo (Júlio).

- E quem primeiro paga a conta é o funcionário pequeno, né? [...] um ou dois funcionários de alto escalão que fez besteira vai colocar na rua como ela [Petrobras] fez [...], mas mesmo assim ele arrasta todo mundo, né? Então aquele camarada que trabalhava certo [...] não tinha nem como chegar perto de um negócio desse [fraude de contratos de alto valor]. Isso vai da diretoria né? A diretoria aprova e desce. Mas o pequeno paga [...] também [...] passa o rodo e vem simbora acabando com tudo (Thiago).

- $\quad[\ldots]$ clima de pós-tsunami, quando a água vai embora, o pessoal tentando se organizar. [...]. Eu acredito que ainda [...] haja [...] mágoa [...] pessoas que perderam funções [...] de gerência, foram sentar em uma baia apertadinha (Mathias).

- $\quad[. .$.$] os técnicos da Petrobras sabem o que estão fazendo e era extremamente importante que deixassem a Petrobras trabalhar com$ os técnicos, tirassem [...] tudo que é ingerência política, fora daqui! Deixa a gente fazer o que a gente sabe fazer. Tem muito gerente executivo que é apadrinhado político, isso pra mim é um câncer [...] tem outras pessoas capacitadas que deveriam estar naquele lugar e não estão (Júlio).

- $[\ldots]$ a gente estava saindo para um almoço de confraternização de final de ano [...] na avenida Paulista [...] um monte de pessoas na rua, a gente ia andando, eles iam varrendo os nossos pés, eu falei 'pra que isso?', 'não, pra limpar a sujeira que vocês [interrompeu a fala]' falei 'olha, vocês estão no lugar errado, a sujeira você vai lá em Brasília'. [...] A Lava-Jato tava no auge (Júlio).

- [...] quebra, um pouco, esse orgulho de ser petroleiro [...] O sentimento é de dupla indignação [...] pelo fato de ter acontecido $\mathrm{e}[\ldots]$ de ter respingado em você um pré-julgamento social. Todos os empregados foram taxados, quase que imediatamente por, se é petroleiro é bandido [...] é corrupto, [...] é ladrão. [...] (Douglas).

\section{Categoria Inicial}

Danos à

Imagem e ao

Clima

Ameaça ao

self 


\section{Figura 8 - Fratura na Identidade Organizacional (continuação)}

\section{Unidades de análise}

- $\quad[. .$.$] colocou um diretor de fora para ser o diretor de compliance, só que o próprio diretor, por ironia do destino, praticou nepotismo$ [...] foi colocando a filha trabalhando [...] (Antônio).

- Pra mim, a Petrobras fez mais um mise en scène mais pra dar uma resposta pra sociedade do que uma coisa efetiva pra melhorar. [...] instituiu com isso foi um sistema de terror [...] hoje uma pessoa assinar um papel, nossa! Pensa vinte vezes, posterga, faz o diabo pra não assinar né? Ninguém quer assinar nada (Júlio).

- Quando eu soube da primeira [...] da prisão [...] eu vibrei muito, [...] como muitos! [...] porque nós sabíamos de tudo e não tinha quem fizesse nada. Só que nós pensávamos que isso ia ser extensivo a todo o corpo que estava minando a Petrobras [...] só estavam querendo pegar pessoas do PT [...], mas tem que pegar os outros também, dos outros partidos [...]. Então, quando nós começamos a desconfiar que a coisa era [...] direcionada, nós começamos a ficar muito revoltados[...] porque [...] o sentimento do empregado da Petrobrás é exatamente esse, nós queremos que apure tudo! (Antônio)

\section{Categoria Inicial}




\section{Reparação Identitária}

O processo de Reparação Identitária ocorre quando, apesar das avaliações ambivalentes experimentadas no desenrolar da crise, os empregados criam uma narrativa de recuperação/superação coerente, isto é, que permite reparar a identidade da Petrobras, reforçando a autocoerência. A reparação começa com a depuração da $I O$, quando o grupo malfeitor é circunscrito, “[...] uma organização criminosa [...]" (Administrador, ver Figura 9) e "[...] uma minoria" (Antônio, ver Figura 9), e expurgado da IO, “[...] isso não representa a Petrobras” (Administrador, ver Figura 9). E, em seguida, há a recuperação da credibilidade, quer dizer, os depoentes avaliam que os novos procedimentos de controle adotados irão evitar novos comportamentos antiéticos. A Reparação Identitária é caracterizada por sentimentos como resiliência, recuperação e superação em um momento que as lideranças parecem estar conseguindo dissipar a ameaça à $I O$. Além de boa-fé, quando, finalmente, as lideranças conseguem desassociar a má conduta da identidade da Petrobras reforçando o autocrescimento. A Figura 9 relaciona as unidades de análise destacadas dos depoimentos às categorias de Reparação Identitária.

A Figura 10 consolida o processo de sensemaking das lideranças intermediárias no Enfrentamento da Crise Ética, processo esse que envolve os estágios de Choque Traumático, Fratura na Identidade Organizacional e Reparação Identitária, com suas respectivas categorias. 
Figura 9 - Reparação Identitária

Unidades de Análise

- O discurso que a empresa adota é que [...] foi vítima e eu creio nisso piamente [...] tinha uma organização criminosa [...] envolvendo empregados da Petrobras e [...] de empreiteiras e políticos [...] como instituição não fez nada pra lesar investidor ou quem quer que seja (Clóvis).

- A questão de roubos é histórica, ela não surgiu com a Lava-Jato, eu costumo falar que [...] o que aconteceu foi porque a empresa cresceu tanto, ela lucrou [...] e a proporção do roubo não diminuiu, a proporção se manteve, então o jogo ficou muito maior, em termos de número. Ela tem se esforçado, mas não é um esforço que está no limite [...], mas, muitas vezes, a minha percepção [...] com relação a ações [...] eles focaram em desvios de conduta em níveis [hierárquicos] que não tem a menor condição de roubar nada [risos] que não vai alterar em nada [...] o pessoal que está atuando na produção aqui que tem que fazer curso de ética [...] sendo que a gente nem tem acesso a nada, quer dizer, fica uma ação generalizada [...] sendo que é, realmente, uma minoria, dentro de um poder [...] um foco muito pequeno [...]. Eu ainda tenho muito orgulho de trabalhar, como sempre tive e eu tenho certeza que esse tipo de coisa que acontece são ações de uma minoria (Antônio).

- As pessoas que participaram de irregularidades na Petrobras, elas foram punidas [...]. A conduta de determinadas pessoas, isso não representa a Petrobras. [...] A Petrobras representa o Brasil (Administrador).

- [...] as pessoas vão pensar muito mais vezes antes de tentar fazer alguma coisa errada. [...] descobriram que não vão ficar impunes, isso é bom. Não estou dizendo que todo mundo que fez alguma coisa errada está sendo punido, mas que está começando a acontecer, isso é importante. O ideal é chegar a 100\% (João).

- [...] fecharam as senhas da rede porque antigamente [...] os arquivos eram liberados na rede, os arquivos de projetos, os projetos básicos, os termos de referência [...] então, todo mundo tinha acesso a tudo e isso facilitava você ter informações pra passar para terceiros e negociar isso [...] a partir de então passou a ter mais controle institucional [...] (Mathias).

- Melhorou muito com as gestões recentes do Pedro Parente, ele procurou deshierarquizar a empresa, botar uma governança mais adequada, mas antes a governança toda que existia era feita pra dá problema né? Feita para decisões fossem tomadas top-down e acabou, às vezes, [...] um middle manager ou [...] um gestor mais sênior sozinho ou um grupo não ia conseguir conter aquela avalanche (Clóvis).

\section{Categorias Iniciais}

Depuração da IO

Recuperação da credibilidade 
Figura 10 - O Enfrentamento das Crises Éticas pelas Lideranças Intermediárias no Sensemaking das Lideranças

Sentidos

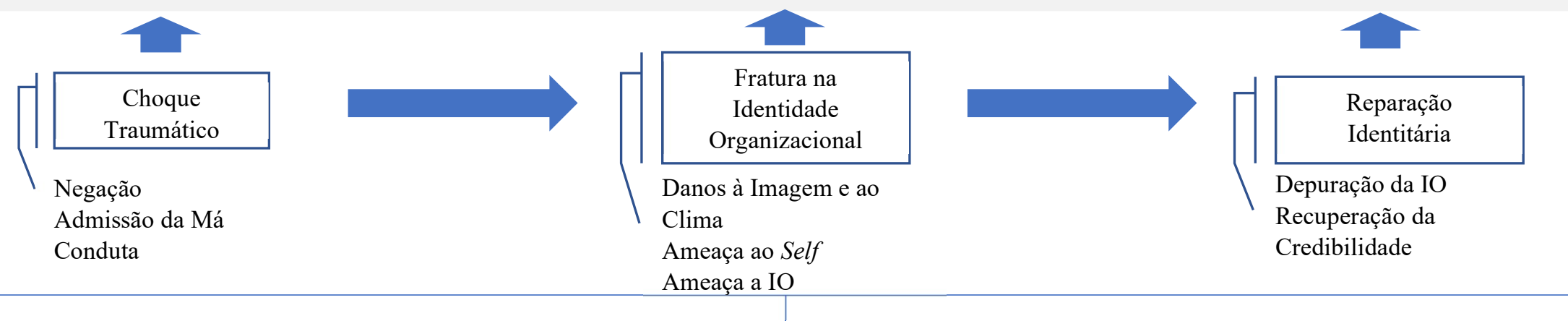

Enfrentamento das Crises Éticas 
A próxima seção discute as dinâmicas observadas entre a Estratégia de Sensegiving da Liderança Executiva e o Enfrentamento da Crise Ética Organizacional pelas lideranças intermediárias, ou seja, o processo de Sensemaking das Lideranças da empresa.

\subsubsection{Sensemaking das Lideranças}

Algumas respostas dos membros da empresa ao processo de Estratégia de Sensegiving da Liderança Executiva foram positivas e outras não. O sentido que parece ter sido unanimemente estabelecido é o da Petrobras como vítima dos crimes de poucos, cujo comportamento não representa a empresa como um todo, assim resguardando a identidade da Petrobras, e reforçando a autocoerência dos membros. Esse sentido relaciona-se 1) ao reconhecimento de que é verdade que os comportamentos antiéticos ocorriam; 2) à aceitação de que a má conduta se tornou de conhecimento público e não há mais como negá-la; 3) à possibilidade de continuidade construída pela crença de que o grupo corruptor foi afastado, circunscrevendo o malfeito e separando-o da IO; e 4) à desvinculação dos sentidos negativos (provenientes desse grupo corruptor) da IO, eliminado (ou atenuado) a ameaça.

As medidas adotadas pela liderança executiva não foram bem aceitas em alguns casos, ou pelo menos, alguns empregados não ficaram convencidos da eficácia de sua operacionalização (mise en scène). Essas diferenças nas avaliações estão relacionadas a forma como cada indivíduo reagiu às contramedidas da liderança executiva, em razão de seus valores e crenças pessoais, além da influência de outras fontes de sensegiving, como sindicato e mídia. Semelhante aos resultados encontrados na pesquisa de Logemann, Rebecca e Cornelissen (2018), os líderes intermediários aderiram à direção apontada pelo sensegiving dos líderes executivos, no entanto, reproduziram o conteúdo de maneira a melhor atender as suas próprias necessidades de construção de sentido e defesa do self.

Ademais, é possível depreender que um dos principais sentidos ameaçados e pelo qual mais se lamenta é o de autocoerência, ou seja, às perdas causadas pela corrupção política ter "respingado" nos membros técnicos. Por fim, a autocoerência é reparada com os sentimentos de resiliência, recuperação e superação.

A Figura 11 sintetiza todo o processo de Sensemaking das Lideranças. 


\section{Figura 11 - Sensemaking das Lideranças}

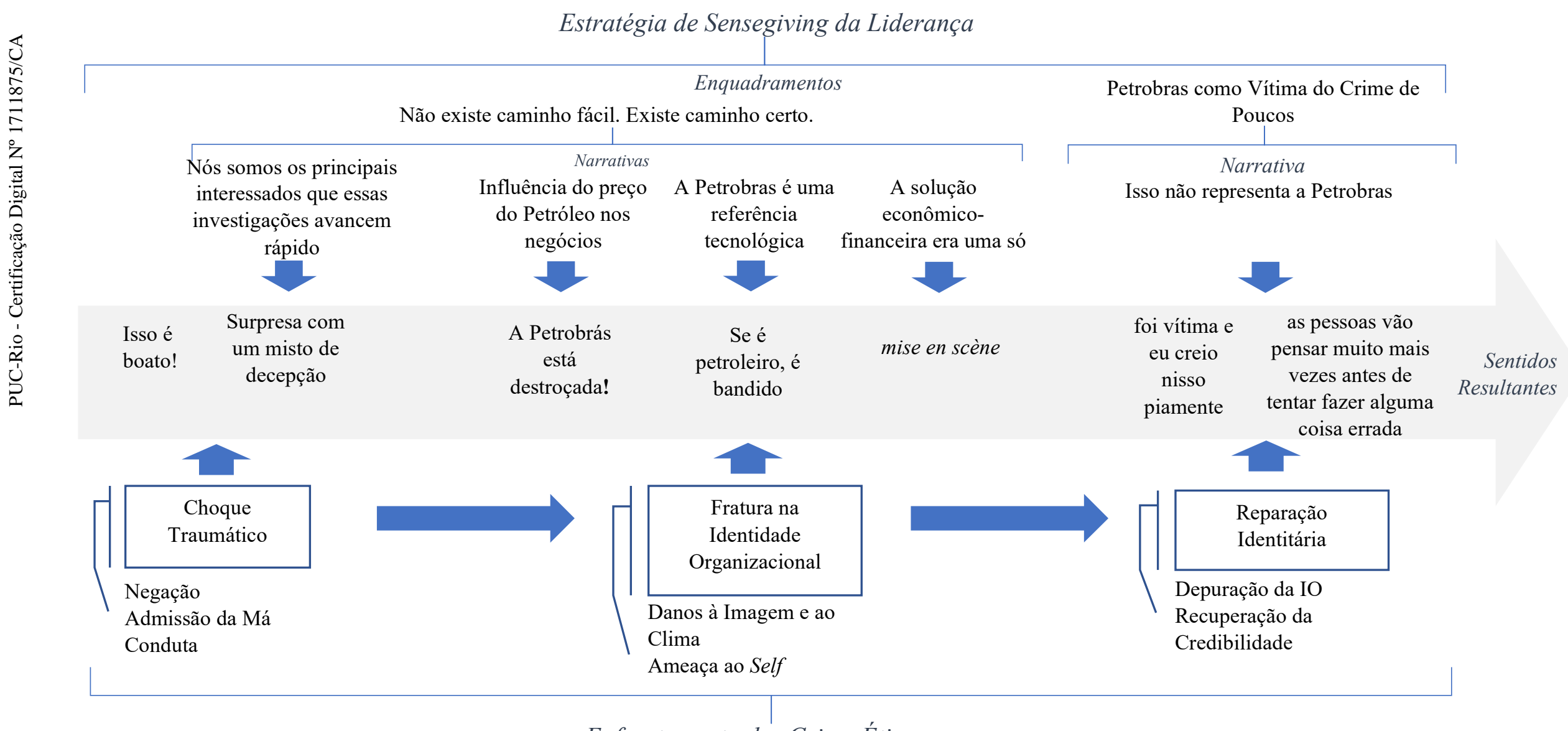

Enfrentamento das Crises Éticas 
A Figura 11 apresenta as narrativas e enquadramentos que perfizeram a Estratégia de Sensegiving da liderança Executiva e o enfrentamento das crises éticas pelas lideranças intermediárias com seus processos subjacentes, o Choque Inicial, a Fratura na Identidade Organizacional e Reparação Identitária. Ao centro, a Figura 11 destaca, por meio de unidades de análise retiradas diretamente dos depoimentos, os sentidos resultantes dessas interações.

\subsection{Discussão dos resultados, achados e limitações}

A Figura 11 apresenta a estrutura completa do Sensemaking das Lideranças. A Estratégia de Sensegiving da liderança executiva foi adotar um discurso apoiado em narrativas e enquadramentos que tiveram ressonância junto aos liderados. Além disso, os sentidos promulgados reforçaram as bases de uma construção positiva do self (autocrescimento e autocoerência) - fortalecendo ou ressignificando aspectos positivos da $\mathrm{IO}$ e dissociando aspectos que poriam ameaçar a IO como o comportamento antiético, ou seja, apartando o malfeito da IO.

Os principais agentes de sensegiving são os líderes do nível executivo, já que tanto as contramedidas quanto o discurso adotado se dão em nível institucional. Vale ressaltar que esses agentes tinham acesso a informações e aos recursos necessários para tanto. Não obstante, as lideranças táticas e operacionais possivelmente também participam no sensemaking dos demais membros, haja vista sua proximidade com eles, não apenas se apoiando nos sentidos produzidos pela liderança executiva para enfrentar a crise, mas possivelmente reverberando esses sentidos para os demais membros do grupo. Todavia, os sensegiving desses níveis não foi diretamente analisado neste estudo, e carece de investigação, de preferência através de pesquisas longitudinais.

No entanto, as lideranças táticas e operacionais não estão complemente convencidas dos sentidos promovidos pela liderança executiva. Alguns líderes apontaram fragilidades na legitimidade da liderança executiva. Eles não acreditam totalmente no compromisso de combate a corrupção e avaliaram algumas contramedidas como injustas. Conforme Logemann, Rebecca e Cornelissen (2018, p. 15) os gerentes e empregados "recorrem à forma e não ao conteúdo do sentido que a eles é "dado" pelos líderes". Os autores também ressaltam com isso a importância de os líderes executivos oferecerem as ferramentas - por exemplo, enquadramentos e narrativas - para que os seus liderados construam sentidos a partir 
delas. Ademais, essa falta de alinhamento ao sensegiving da liderança executiva (guardadas as diferenças nos processos cognitivos individuais) parece estar associada ao sensegiving da liderança sindical e possivelmente, ao sensebreaking não intencional das subseqüentes mudanças de presidência da companhia. Além disso, existem outras fontes de sensegiving possíveis que não foram avaliadas aqui. Assim, os sentidos resultantes do sensemaking foram: as mudanças foram positivas, isto é, a empresa aprendeu (reforço do autocrescismento); os empregados, em maioria, possuem boa-fé (reforço da autocoerência) e; a empresa é resiliente (reforço da autocoerência). O enquadramento Petrobras como vítima do crime de poucos parece ser dominante e aponta para a continuidade da IO (reforço da autocoerência).

Vale ressaltar que apesar da análise dos vídeos institucionais abordar alguns elementos cenográficos, ela não pretendeu realizar uma análise discursivoimagética dessas fontes de dados. 


\section{Estudo 3 - Como os Empregados Dão Sentido ao Fim da Identidade Organizacional}

\subsection{Introdução}

Alguns estudiosos usaram a metáfora da morte organizacional para se referir a uma ampla gama de eventos organizacionais, potencialmente traumáticos, como por exemplo, falhas de negócios, de projetos ou de organizações, downsizing, fechamento de locais de trabalho e fábricas, reestruturação, fusões e aquisições (BELL; TAYLOR, 2011; ARMAN, 2014). Bell (2012) trata da morte em nível coletivo como a perda da estrutura fundamental de significado do grupo, isto é, de sua identidade. Em outras palavras, a morte organizacional é a perda da representação compartilhada pelos membros de uma organização, a sua identidade organizacional, quer dizer, a visão de mundo desse grupo, seu modo particular de fazer as coisas, de interagir e de ser (MACHADO-DA-SILVA; NOGUEIRA, 2001). Harris e Sutton (1986) destacam ainda que a morte organizacional representa a perda de uma arena social compartilhada, uma ameaça profunda à estrutura de relações sociais.

Em um contexto em que as várias formas de morte organizacional são cada vez mais frequentes (BELL; TAYLOR, 2011; ARMAN, 2014), como são os processos mobilizados pelos empregados para dar sentido a esses eventos traumáticos? Esta pesquisa objetiva compreender os processos pelos quais os empregados dão sentido ao fim da identidade organizacional. A pesquisa amplia e aprofunda o entendimento sobre reações dos empregados ao fim da identidade organizacional sob a perspectiva processual e psicossocial, expandindo esse campo de conhecimento, haja vista que os estudos existentes tem como foco os estágios psicológicos (BELL; TAYLOR, 2011; FRIEDRICH; WÜSTENHAGEN, 2015), aplicação de metáforas relacionadas à morte (BELL, 2012; ARMAN, 2014) ou a análise das narrativas (GERSTROEM, 2014).

A análise se baseou em dados obtidos através de entrevistas em profundidade conduzidas com nove empregados e quatro ex-empregados da BR Distribuidora (doravante, BR) que vivenciaram o processo de privatização da companhia. Destacam-se três momentos nesse processo, 1) o follow on que é o marco da privatização, ou seja, quando as ações ofertadas ao mercado superaram $50 \%$ do total de ações e a BR deixou de ser uma subsidiária da estatal Petrobras, 2) o anúncio do 
PDO - Programa de Demissão Optativa e 3) o período Pós-PDO. O estudo observa diferentes processos de enfrentamento do fim da identidade organizacional pelos empregados: (1) processos associativos de acomodação, de adaptação ou de assimilação e; (2) processos dissociativos de descomprometimento, desidentificação e ressignificação de si. Além disso, o estudo aponta que a intensidade da ameaça ao self é determinante no tipo de processo de associação ou dissociação e, também, na forma como os membros experimentam o fim da identidade organizacional - como perda ou como mudança.

\subsection{Referencial Teórico}

\subsubsection{Processos Sociais, Identificação e Identidade}

Berger e Luckamnn (1966) apresentaram uma teoria sobre o processo de construção social da realidade, quer dizer, como as relações sociais impactam no modo como os indivíduos interagem com (o que eles entendem como) a realidade. Para os autores, há, pelo menos, duas formas de perceber a realidade na sociedade, como uma realidade objetiva, concreta e subjetiva, dotada de sentidos. Assim, a sociedade é uma realidade fora do indivíduo, isto é, o indivíduo não nasce membro de uma sociedade, mas com pré-disposição a se tornar um membro dela, quer dizer, de ser socializado. Para tanto, existe o processo de interiorização no qual o indivíduo absorve a realidade em seu entorno. E, por meio da interiorização, ele criará as suas concepções de sociedade, realidade e identidade.

Primeiro, o indivíduo adquire uma percepção de mundo circunscrita as suas vivências no seio familiar e, assim, é inserido em um mundo social específico, com os seus próprios sentidos. Depois, ele passa a conviver com vários outros grupos sociais e, desta forma, começa a absorver novos padrões culturais de comportamento e a experimentar outras percepções de mundo. Nesse sentido, os processos de socialização sempre envolvem modificações no microcosmo do indivíduo e "Ao mesmo tempo, a maior parte dos processos de socialização [...] liga o indivíduo às estruturas complexas do macrocosmo. As atitudes que o indivíduo aprende através da socialização geralmente se relacionam com sistemas amplos de significados e valores [...]" (BERGER; BERGER, 1977, p.214). E, é por meio dessas interações, entre microcosmo e macrocosmos, que uma identidade será assimilada ao indivíduo (BERGER; BERGER, 1977). Nesse sentido, Lakatos 
(1990) apresenta alguns processos sociais, de associação e dissociação, nos quais a identidade individual se desenvolve e se relaciona com a sociedade, ou com os diversos grupos sociais. Esses processos sociais são do tipo cooperação, adaptação, acomodação e assimilação, nos casos de associação, e dos tipos competição e conflito, nos casos de dissociação. O Quadro 8 apresenta a explicação dos tipos de processos associativos.

Quadro 8. Processos Sociais Associativos

\begin{tabular}{|c|c|}
\hline Adaptação & $\begin{array}{l}\text { Pode ocorrer, principalmente, em nível de pensamento - em que há a absorção } \\
\text { de elementos da cultura, representações de imagens, categorias mentais, } \\
\text { conhecimentos e maneiras de pensar do grupo. "A adaptação social de um } \\
\text { indivíduo ao grupo não significa necessariamente conformidade social, mas } \\
\text { supõe a utilização de certa margem de liberdade ou de autonomia que o meio } \\
\text { concede" (LAKATOS, 1990. p.87). }\end{array}$ \\
\hline Acomodação & $\begin{array}{l}\text { Tem como objetivo diminuir o conflito entre indivíduos ou grupos. "É um } \\
\text { ajustamento formal e externo, aparecendo apenas nos aspectos externos do } \\
\text { comportamento, sendo pequena ou nula a mudança interna, relativa a valores, } \\
\text { atitudes e significados" (LAKATOS, 1990.p.87). }\end{array}$ \\
\hline Assimilação & $\begin{array}{l}\text { "Assimilação e o processo social em virtude do qual indivíduos e grupos } \\
\text { diferentes aceitam e adquirem padrões comportamentais, tradição, sentimentos e } \\
\text { atitudes da outra parte." (LAKATOS, 1990, p.88) }\end{array}$ \\
\hline
\end{tabular}

Fonte: Adaptado de Lakatos (1990)

\subsubsection{Morte Organizacional e Sentidos}

Para a maioria dos autores, a morte organizacional se refere a um final literal, mas também a um final metafórico (ARMAN, 2014). Muitas pesquisas têm deduzido que nesse processo organizacional ocorrem comportamentos semelhantes aos descritos no modelo de curva de crise de Kübler-Ross (1969). Tal modelo procurou explicar as reações de pacientes terminais no hospital em cinco estágios, cada um caracterizado por uma emoção principal: negação, raiva, barganha (ou negociação), depressão e, finalmente, aceitação. Assim, as metáforas da morte são projeções dedutivas ou um "exercício hermenêutico" de usar o visível na situação organizacional, isto é, usar o comportamento observado como pista para uma metáfora subjacente (ARMAN, 2014). Esse artifício é útil para explicar as diferenças de significados e ações observadas nos relatos analisados (ARMAN, 2014).

Nesse cenário, Bell e Taylor (2011) alertam para a necessidade de tomar o devido cuidado com generalizações de achados de estudos sobre luto individual para contextos organizacionais. No entanto, os autores destacaram que as emoções compartilhadas coletivamente são semelhantes às emoções no nível individual, e, 
também, às reações associadas ao luto (HARRIS; SUNTTON, 1986; FRIEDRICH; WÜSTENHAGEN, 2015). A maior parte dos empregados de organizações em processo de morte que Harris e Sutton (1986) ouviram, compararam o fechamento a algo um pouco pior que uma doença grave ou a um divórcio ou morte do cônjuge.

Assim, as perspectivas dominantes têm abordado as reações individuais às demissões decorrentes de morte organizacional em termos de: como os empregados percebem a maneira como foram tratados pela gerência (ARMAN, 2014) e se a mudança foi efetivamente gerenciada. Por exemplo, para Cunningham "As informações em espera e incompletas promovem a dependência e a possibilidade crescente de que o membro da organização nunca lide verdadeiramente com sua raiva pelo término" (1997, p.484). Desta forma, é necessário que os líderes deem condições para que os empregados, de maneira independente, experimentem cada uma das etapas do luto.

Para Goltz (2018, p.436), “é necessário um equilíbrio entre pausar para aceitação e avançar em direção à mudança". Para a autora, é preciso que os agentes de mudança aceitem os empregados resistentes e suas emoções. E, deem tempo suficiente para que estes alcancem uma aceitação consciente de suas experiências emocionais negativas. Em outras palavras, a falta de transparência ou a comunicação ineficiente acerca da morte organizacional furta do empregado o tempo necessário para lidar com a perda, e também, dificulta a avaliação de alternativas.

Nesse sentido, as cerimônias de despedida em organizações que estão morrendo oferecem certa materialidade à morte organizacional. Nas palavras de Harris e Sutton (1986, p.21), "Uma cerimônia de despedida fornece evidências inequívocas e vívidas da morte de uma organização. Isso ajuda as pessoas a evitarem a negação [...]". Tais cerimônias, servem ainda para manter e promover o bem-estar individual, por incentivar a troca de apoio emocional - isso ajuda os membros que estão saindo a romper os laços sociais de uma maneira socialmente aceitável. Para os que ficam, as cerimônias de despedida são oportunidades para os gerentes e organização promoverem a coesão do grupo, desempenho das tarefas e as relações positivas com as partes interessadas externas (HARRIS; SUNTTON, 1986). Em outras palavras, satisfazer as normas sociais sobre o tratamento dos membros; promover uma imagem de destino compartilhado, entre administração e empregados, restaurando assim, a boa vontade contra comportamentos 
contraproducentes (como sabotagem); disseminar informações; dizer de maneira simbólica que o fechamento é uma realidade e; gerenciar as impressões externas.

Por outro lado, Gabriel (2012) apresentou a teoria do miasma organizacional, um estado de poluição material, psicológica e espiritual que pode ser desenvolvido em organizações que sofreram transformações súbitas e traumáticas. Como é o caso, por exemplo, de organizações que passam de uma ética de serviço público para uma ética voltada para o mercado (GABRIEL,2012). Em todos os casos, o fator crucial de desencadeamento do miasma é o descarte (sic) de muitos dos membros da organização, sem rituais de separação ou luto. E, além disso, "a presença de pessoas [...] condenadas, mas que ainda não partiram [...]" (GABRIEL, 2012, p.1147), os “cadáveres ambulantes" (walking corpses). Esses empregados passam a se enxergar como objetos desprovidos de aspiração e descartáveis. São alguns dos seus sentimentos, a inadequação, o desânimo, a depressão, a desconfiança, a suspeita e uma expectativa de banimento iminente.

Assim, um dos interesses de pesquisa tem sido entender por que alguns chagam à aceitação enquanto outros ficam paralisados em estágios intermediários do luto. Para a corrente majoritária, a morte organizacional é um processo de desconexão e reconexão em resposta à mudança organizacional, de objetivos, crenças e valores (SUTTON, 1987). Então, em outras palavras, alguns pesquisadores, como Cunningham (1997), procuraram compreender o porquê de certos grupos e indivíduos se desconectarem e se reconectarem com mais facilidade que outros, se adaptando ao novo ambiente.

$\mathrm{Na}$ contramão disso, Bell e Taylor (2011) criticam os modelos de estágio psicológico que é associado à lógica gerencialista, que incentiva a conformidade, e, também, a valores culturais arraigados nas sociedades ocidentais modernas, condicionadas a ética protestante e que tendem a separar as emoções em positivas e negativas. Além disso, abordam a morte organizacional como um ponto final, a partir do qual os mortos devem ser removidos do mundo dos vivos. Para os autores, esses modelos que promovem desapego como solução para a perda coletiva, negligenciam os desenvolvimentos teóricos recentes a respeito do luto individual, isto é, a teoria dos vínculos contínuos. Tal teoria explora as diversas formas pelas quais os vivos mantêm relações com os que já se foram, seja no nível emocional, social ou material, por meio de representações internas simbólicas e duradouras. Para os autores, essas relações são dinâmicas, evoluem ao longo do tempo e podem 
ter efeitos positivos para os sobreviventes. Exemplo disso, é o estudo de Gerstroem (2014, p.89) onde ela "[...] fornece evidências empíricas sobre as maneiras pelas quais a identidade organizacional herdada de uma organização morta desempenha um papel substancial em uma organização viva"

De uma forma ou de outra, a importância das trocas sociais, principalmente, no contexto de trauma organizacional, encontra amparo na literatura sobre sensemaking - processo social contínuo situado nas micro-práticas de interação, conversas e ações por meio das quais as pessoas dão sentido as suas experiências (ALLARD-POESI, 2005). Além de buscar compreender as suas experiencias, as pessoas, também, criam as próprias realidades que estão interpretando por intermédio das ações que encenam no sensemaking, nas palavras de Weick (1988, p.306) "Pessoas que atuam [act $]$ em organizações geralmente produzem estruturas, restrições e oportunidades que não existiam antes da ação". Desta forma, elas procuram tornar-se responsáveis por si mesmas e pelos outros (WEICK, 2011). Ademais, o sensemaking é mediado por uma necessidade de manutenção ou preservação de uma identidade contínua e positiva (WEICK, 1995). Identidade essa que é continuamente moldada nas interações.

Assim, o sensemaking é desencadeado, principalmente, por algo que interfere na constituição positiva da identidade ou por algo que interrompe o fluxo de ações e de projetos que não podem ser facilmente rejeitados ou minimizados (ALLARDPOESI, 2005). Então, quando ocorre esse tipo interrupção nas organizações, como é o caso do fim da identidade organizacional, os empregados precisam determinar muitas coisas ao mesmo tempo como "O que aconteceu?", “O que isso significa para os outros e para mim mesmo?”, “O que isso significa para as minhas ações subsequentes?” (ALLARD-POESI, 2005, p.7). Dito de outro modo, a interrupção impacta projetos que se interpõem a constituição contínua de uma identidade positiva. E, para responder as questões anteriormente colocadas, as pessoas precisam de valores e, também, ter clareza sobre quais projetos tem prioridade na constituição positiva de suas identidades. 


\subsection{Metodologia}

Este estudo trata do caso da privatização da BR Distribuidora. Não é possível discutir os sentidos construídos em torno do fim da identidade organizacional da BR sem compreender o lugar dessa empresa como símbolo nacional. A BR Distribuidora tem a maior rede de postos do Brasil e é líder no mercado de distribuição de combustíveis e lubrificantes em volume de vendas (BR DISTRIBUIDORA, [s.d]). Foi criada em 12 de novembro de 1971 com o objetivo de distribuir derivados de petróleo e álcool carburante da Petrobras (BR DISTRIBUIDORA, [s.d]). Subsidiária da Petrobras até 2019, em seu site a história da empresa mãe e da subsidiária se mesclam à história nacional (BR DISTRIBUIDORA, [s.d]). Mesmo privatizada, a BR manterá o nome Petrobras por mais 20 anos. Quer dizer, sua história e imagem estão muito imbricadas com as da Petrobras (que é identificada fortemente como símbolo nacional) e seu simbolismo.

Foram realizadas 13 entrevistas com (ex)empregados da BR Distribuidora que vivenciaram o IPO, o follow on e o PDO. Os entrevistados foram contatados via aplicativo Linkedln. Todas as entrevistas foram semi-estruturadas e contaram com roteiro mínimo. As entrevistas foram realizadas via ligação de Whatsapp e foram gravadas, com exceção de Juarez, que não se sentiu à vontade em conceder entrevista por WhatsApp, ao invés disso, pediu que o roteiro fosse enviado por email e respondeu em um único texto, uma narrativa da origem à privatização da $\mathrm{BR}$, com o foco em sua carreira dentro da empresa.

O tempo na empresa dos entrevistados variou de 3 a 26 anos. Embora haja informações detalhadas sobre os cargos específicos ocupados pelos participantes ao longo de suas carreiras na empresa, optou-se por omitir a unidade de alocação e o cargo específico, a fim de assegurar o anonimato dos participantes. Os nomes utilizados para identificar os participantes neste estudo são fictícios. Esses profissionais atuam ou atuaram na BR nas áreas de tecnologia, regulação, comercial, recursos humanos, segurança patrimonial, gestão de processos, operações, comunicação e infraestrutura. O Quadro 9 apresenta os perfis resumidos de todos os entrevistados. 
Quadro 9 - Perfil dos Entrevistados

\begin{tabular}{cccc}
\hline Nome & $\begin{array}{c}\text { Tempo na } \\
\text { empresa } \\
\text { (anos) }\end{array}$ & Cargo/Área & Vínculo Empregatício \\
\hline Laércio & 3 & Analista Pleno & Empregado \\
Valéria & 22 & Analista Sênior & Optou pelo PDO \\
Amanda & 8 & Analista Sênior & Empregada \\
Marion & 8 & Analista Sênior & Empregada \\
Davi1 & 11 & Gerente & Empregado \\
Jerônimo & 5 & Analista & Empregado \\
Mauro & 26 & Assessor [...] sênior & Optou pelo PDO \\
Juarez & 35 & Gerente & Optou pelo PDO \\
Ronaldo & 9 & Executivo & Empregado \\
Sérgio & 9 & Analista Pleno & Empregado \\
Caio & 22 & Gerente & Optou pelo PDO \\
Renato & 16 & Analista Pleno & Empregado \\
João & 10 & Analista Pleno & Empregado \\
\hline${ }^{1}$ Davi foi o único entrevistado que não prestou concurso para entrar na BR, ele foi incorporado ao quadro da \\
empresa por meio de uma aquisição de postos de distribuição de outra companhia. \\
${ }^{2}$ O depoimento de Jerônimo não foi analisado como processo, pois foi a primeira entrevista, de caráter \\
exploratória, e não percorreu todo o roteiro.
\end{tabular}

Categorias iniciais foram identificadas a partir dos depoimentos recolhidos por meio das entrevistas. Essas categorias foram organizadas de maneira que traduzissem os sentidos elaborados em torno dos eventos que compõe a privatização. Algumas dessas categorias, os processos sociais de associação, foram tomadas da literatura (LAKATOS, 1990). No entanto, novas categorias de processos sociais de dissociação emergiram a partir da análise dos dados.

\subsection{Análise}

As próximas seções tratam do enfrentamento do fim da identidade organizacional por meio de processos sociais associativos e dissociativos, as emoções com as quais eles se relacionam e os sentidos que deles emergem. A análise identificou três momentos de inflexão para os depoentes - quando eles tiveram seu fluxo de ação e projetos interrompidos e tiveram que procurar dar sentido ao que estava acontecendo, o que aquilo significava para eles mesmos e para os outros e quais a ações deveriam tomar. São esses momentos: i) o follow on, quando mais ações são ofertadas ao mercado, ultrapassando $50 \%$ do total de ações - o que marca, de fato, a privatização da BR; ii) o anúncio do PDO, quando a empresa anuncia o Programa de Demissão Optativa e fica clara a intensão de 
downsizing; iii) e o Pós-PDO que é o momento seguinte ao ápice do processo de fim da IO.

Ademais, foram identificadas dois condicionantes no processo de sensemaking dos depoentes:

(1) A manutenção do vínculo empregatício com a BR;

(2) A intensidade da ameaça ao self.

A Manutenção do Vínculo empregatício é o primeiro condicionante a moldar a realidade a qual os indivíduos estão dando sentido, quer dizer, a partir do momento que os empregados decidem por permanecer ou romper com a empresa, eles se engajam em processos de associação ou de dissociação da identidade organizacional, respectivamente.

Já, a intensidade de ameaça ao self define a vivência do fim da IO. Em outras palavras, quem teve o self mais ameaçado experimentou o fim da IO como perda e quem teve o self menos ameaçado experimentou o fim da IO como mudança. E, assim, cada um desses processos resultou em um sentido para o fim da IO.

Além disso, a intensidade de ameaça ao self que o fim da IO representa determina o tipo de processo de associação ou de dissociação, bem como os sentidos desdobrados a partir dessa experiência. Assim, quando a ameaça ao self foi percebida como baixa, os processos mobilizados foram de associação por assimilação ou de dissociação por ressignificação de si; quando a ameaça ao self foi percebida como média, os processos mobilizados foram de associação por adaptação ou dissociação por descomprometimento; e quando a ameaça ao self foi percebida como alta, os processos mobilizados foram de associação por acomodação ou de dissociação por desidentificação. Esses processos e seus desdobramentos são melhor esclarecidos nas próximas seções.

Nas próximas seções da análise, são apresentados os processos identificados a partir dos depoimentos e os respectivos sentidos resultantes deles. Primeiro os processos sociais de associação à $\mathrm{IO}$, quais sejam, (1) processo associativo por acomodação, (2) processo associativo por adaptação e (3) processo associativo por assimilação e, em seguida, são apresentados os processos dissociativos emergentes, quais sejam, (4) processo dissociativo por ressignificação de si, (5) processo dissociativo por descomprometimento e (6) processo dissociativo por desidentificação. 


\subsubsection{Os Processos Associativos de Enfrentamento}

\section{Processo Associativo por Acomodação}

O principal ponto de inflexão no processo de privatização da BR para Laércio, Marion e Sérgio foi o anúncio do PDO. Quer dizer, eles já esperavam pela privatização, com exceção de Marion que, nas palavras dela, "não queria acreditar" (negação), mas a maneira como o PDO foi conduzido frustrou as expectativas deles.

[...] a transição foi bem caótica para os trabalhadores e a comunicação foi bem dura [...] pessoas tinham ideia de que isso poderia acontecer [...], mas acharam que seria diferente né, [...] que as pessoas teriam tempo para pensar, teria um tempo de estabilidade o que não ocorreu né. [...] não precisa ser dessa maneira. Teria resultados mais positivos. Acho que não precisava. A comunicação não foi muito transparente, foi ameaçadora. (Laércio)

O clima depois dessa apresentação de novembro [anúncio do PDO] despencou muito [...] a gente não [...] tava naquela expectativa que ia mudar muita coisa, mas veio um negócio tipo um trator e atropelou todo mundo [...]. (Sérgio)

Eles tinham poucas informações para tomar decisão, tinham acesso a proposta para aderir ao PDO, em cada caso, mas não sabiam o quanto os seus salários seriam reduzidos ou se a empresa os manteria caso não aceitassem a proposta (do PDO). Em outras palavras, neste ponto, eles compreendiam um pouco melhor o que estava acontecendo, pois a empresa já havia sido privatizada (follow on), mas não o que isso significaria, na totalidade, para eles. Mesmo diante da falta de informações, eles tinham que agir, e, no caso, eles optaram por permanecer na empresa por acreditarem que esta ação era mais apropriada a manutenção de seus projetos pessoais.

[...] eu até pensei, a princípio, em sair, mas não compensava, 'vou pagar pra ver, vou ficar'. Eu fiquei aquele tempo meio tenso [...]. (Sérgio)

Eu tive muito medo, principalmente, por causa da área de [...] que é uma área terceirizável [...]. Então, eu tive muita vontade de desistir [...] e eu posso ser mandada embora [...] eu paguei pra ver mesmo. E meu marido me incentivou [...]. (Marion)

Ao "pagar para ver", eles estavam moldando a suas situações, estavam agindo e construindo suas realidades, isto é, estavam tentando tornar-se racionalmente 
responsáveis por si mesmos, mesmo com informações insuficientes. E, a partir desse agir, dessa tomada dessa decisão, eles criaram uma nova realidade ao mesmo tempo que coletavam e interpretavam as novas informações dessa realidade.

João teve um comportamento um pouco diferente. Ele já esperava pela privatização e sofreu bastante com essa expectativa, e, inclusive, teve depressão. Quando houve o anúncio do PDO, João já tinha passado pelo sentimento de perda, ainda que ele não tenha experimentado o luto em sua completude até hoje, por ainda está vinculado a empresa.

Cheguei a ter depressão, tive que ir a psiquiatra, psicólogo foram mais ou menos ai de 6 a 8 meses [...] para recuperar. Quando chega a privatização, eu já tinha sofrido antes, então eu fui me preparando, eu percebi que a coisa era inevitável. (João)

Laércio, Marion, Sérgio e João são os depoentes que mais se aproximam da descrição de Gabriel (2012) de "cadáveres ambulantes" (walking corpses). Os quatro continuam na $\mathrm{BR}$, mas se sentem ameaçados com a possibilidade de demissão, dadas as pistas que percebem no ambiente.

[...] O clima tá pesado porque as pessoas ficam com medo de não estarem produzindo, de estarem sendo observadas, se estão adequadas ao novo perfil da empresa que está por vir. Na verdade, a maioria tem medo de, assim, eles estão colocando pessoas novas pra dentro com um salário menor, sendo indicados e a gente que foi aproveitado [...] e continuou com o salário alto, é uma questão de tempo pra ser mandado em bora. Essa é a percepção minha e de algumas pessoas próximas a mim. (Marion)

A gente fica na tensão de como [...] tá primarizando muita gente em uma condição bem [...] assim, a um custo bem mais baixo, a gente tem medo que a médio [ou] longo [prazo], a gente também vai rodar. Eu não crio muito expectativa de ficar muito tempo não, dada as situações que eu tenho observado. (Sérgio)

[..] a gente tem uma expectativa, assim, muito clara de que nós vamos permanecer na empresa porque era necessário um número mínimo de empregados que conduzissem o processo [...]. Então, [...] a gente está esperando a hora de ser demitido. (João)

Por terem permanecido na BR, mas não terem alterado seus valores, atitudes e significados, isto é, por terem se ajustado apenas formal e externamente à nova IO, Laércio, Marion, Sérgio e João tiveram o seu comportamento enquadrado no 
processo associativo de acomodação. É difícil mensurar, no entanto, até que ponto essa atitude não poderá moldar a realidade, quer dizer, o quanto esse comportamento pode contribuir para o desfecho esperado, o da demissão.

Assim, a experiência do fim da IO (principalmente, a partir do anúncio do PDO) foi bastante difícil para Laércio, Marion, Sérgio e João que a descreveram como "caótica" e "ameaçadora", resultando em sentimentos como de tensão e medo e, no limite, depressão (caso de João). No entanto, apesar de sentirem-se ameaçados, eles priorizaram os seus projetos pessoais em curso quando decidiram permanecer na BR. Ainda assim, eles vivenciaram uma perda que, de acordo com a crença deles, ainda não se materializou.

\section{Processo Associativo por Adaptação}

Amanda foi a única depoente a se engajar no processo associativo de adaptação. Ela conscientemente absorveu elementos da nova IO, sem se conformar completamente com eles. Amanda já esperava pela privatização e optou por permanecer na BR ainda que tenha ficado chocada, tensa e com medo, em razão da maneira como ocorreu o downsizing.

Tudo aconteceu muito rápido [...] foi um choque porquê [...] as coisas vão mudar, mas a cultura da empresa não muda na mesma velocidade. [...] eles deram uma semana pras pessoas decidirem o seu destino. Uma semana é um prazo muito curto pra pessoa tomar uma decisão muito grave na sua vida. [...] Foi um momento de muita tensão. [...]. Pelo o que eu vi, o que eu presenciei foi algo que eu espero nunca mais passar na minha vida. [...] então aquilo mexeu muito comigo, aquilo ali foi dificil. (Amanda)

Ela ressignificou a sua relação com a IO e ajustou a sua própria identidade "Hoje eu tenho outro pensamento, [...] sou uma nova pessoa, depois do que aconteceu. Hoje eu vejo a empresa com outros olhos". Ademais, ela encarou o fim da IO como um novo começo com oportunidades. Amanda parece sentir-se no controle de seu próprio destino na organização.

"Eu quis aprender coisas novas, eu achei que estava no momento de ir pra outra área. [...] eu pensei 'a empresa é nova, é tudo novo'[...]." (Amanda) 


\section{Processo Associativo por Assimilação}

Ronaldo e Renato esperavam pela privatização e avaliaram que o PDO foi bom para os empregados financeiramente, mas não concordaram com a maneira como foi conduzido. Em outras palavras, para eles, quando a empresa ofereceu o PDO indiscriminadamente, com um prazo curto para aderir e sem dar informações suficientes do que ocorreria com quem não aderisse, ela se dispôs a abrir mão de bons e maus empregados.

A empresa fez um plano de demissão e tal, eu enxergo que ela fez até de uma forma boa porque quem não quisesse ficar no modelo atual, podia seguir o seu caminho e a empresa deu um respaldo financeiro pra isso. [...] não foi muito bacana não [...]. [...] ela abriu mão, do jeito que ela fez, de muita mão de obra qualificada, eu acho que ouve um equívoco nessa parte, tanto que depois eles tentaram convencer alguns a ficarem e as pessoas não quiseram mais. (Ronaldo)

E a situação era muito incerta pra quem ia continuar. O que foi deixado claro foi o seguinte, tinha esse incentivo [...]. mas quem ficasse não ia ter certeza de como seriam as novas condições de trabalho na nova BR. Você sabia que ia ter redução de salário, mas não falava quanto ia reduzir [...]. Era uma decisão que você tinha que tomar com base em expectativa, meio no escuro. [...]. (Renato)

Ronaldo e Renato se engajaram no processo associativo de assimilação, pois optaram por permanecer na BR. Além disso, esses depoentes relataram sentimento de tranquilidade, serenidade e segurança durante o PDO, além de senso de oportunidade. Eles encaram o fim da IO como um processo de mudança, não se sentem ameaçados e demonstram que acreditam ter o controle de seus destinos na organização.

[...] eu como [profissional] de mercado entendo que eu teria espaço na companhia [...], mas muita gente ficou, ficaram doente, mas eu levei tranquilo [...] agora tá todo mundo com as energias voltadas para as inovações que a empresa tá trazendo, eu acho que já é superado [...]. Na verdade, as pessoas que ficaram foram as pessoas que acreditaram [...] eu sei que a empresa me enxerga diferente [...], mas não me incomoda como ela me olhava antes $e$ como me olha hoje. [...]. (Ronaldo)

Então, a princípio, foi até interessante de um ponto de vista de carreira. [...] O nosso gerente, nesse período [...] ele se mostrou muito disponível [...] ele não podia falar com todas 
as letras, mas ele deu a entender que no meu caso, eu seria aproveitado. (Renato)

Davi também se engajou no processo associativo de assimilação, as suas percepções são semelhantes às de Ronaldo e Renato, com exceção da condução do PDO que ele acredita que não poderia ter sido feita de outra maneira. Ele, também, foi o único que relatou não ter, se quer, lido a proposta para adesão ao PDO.

[...] a gente assistiu [reunião de anúncio do PDO] por videoconferência. [...]. Assim, eu sempre busquei entender tudo isso com muita serenidade, eu não entrei em desespero porque [...] eu nem abri pra olhar de quanto era a minha indenização, [...], em momento algum eu cogitei sair da empresa [...] eu achei que teria até mais oportunidades se eu continuasse na empresa e ai eu resolvi ficar. Em menos de três meses [desde o anúncio do PDO] eu fui promovido de função. [...] [sobre o PDO] na minha percepção foi que ela fez do jeito que precisava ser feito. Para ela conseguir fazer o que ela queria fazer, ela não tinha outra opção e ela tentou minimizar os impactos [...].

Esse assunto de salário reduzido acaba sendo um assunto superado porque é quase assim, é o que tem pra hoje e se você ficou, você topou, então não tem que ficar mais se lamuriando [...].

$E$ as pessoas que entraram estão motivadas pela oportunidade de trabalhar em uma empresa do tamanho da petrobras distribuidora! [...] Ainda mais agora que eu tenho uma equipe sob mim, então a minha percepção é que eu tenho uma equipe hoje motivada. (Davi)

A atitude de Davi, para além de ter decidido ficar na BR, isto é, o seu comportamento a partir dessa decisão, colaborou para a constituição de sua nova realidade. No entanto, a avaliação de Davi em relação a condução do PDO, por parte da administração da BR, está atravessada pela sequência de eventos positivos para ele que seguiram a sua decisão, já que o sensemaking é um processo retrospectivo. Ademais, é importante destacar que apesar de ter assimilado a nova IO, ele evoca a antiga IO quando se refere a grandeza da Petrobras Distribuidora, quer dizer, a BR já não é mais da Petrobras.

A próxima seção trata dos novos processos de dissociação que emergiram da análise dos depoimentos. 


\subsubsection{O Processos Dissociativos de Enfrentamento}

Todos os empregados entrevistados que se engajaram em processos dissociativos o fizeram optando por aderir ao PDO. Eles já esperavam pela privatização e, alguns, a enxergavam como algo positivo.

\section{Processo Dissociativo por Ressignificação de Si}

Juarez foi o único depoente que aderiu ao PDO com um senso de oportunidade de recomeço, como se um ciclo estivesse sido encerrado e ele estivesse iniciando outro, quer dizer, ele não vivenciou o fim da IO como perda, mas como mudança, uma oportunidade transformar a si mesmo. Por isso, o seu processo de dissociação foi classificado como ressignificação de si. Ele já esperava pela privatização e acredita que a empresa agiu da melhor forma possível com os seus empregados. No entanto, ele reconhece que a IO mudou completamente e que é necessário criar um novo propósito que seja bom o suficiente para que os empregados possam se engajar. Lembrando ainda que Juarez não concedeu entrevista por whatsapp, mas pediu o roteiro e respondeu de maneira geral as perguntas norteadoras da entrevista em um único texto.

Todo o processo de privatização da empresa sempre ocorreu de maneira transparente a todos os empregados, para fazer frente ao item de excesso de empregados, ao invés de uma demissão pura e simples, como ocorre na maioria das empresas, foi oferecido a todos um bom programa de desligamento que foi aceito de bom grado por muitos e a BR, para os empregados que ficaram, adotou a política de negociação individual do contrato de trabalho, passando a pagar os salários em de acordo com o mercado. [...] vai exigir dos seus atuais administradores criar um bom PROPÓSITO [sic] pelo qual os seus atuais empregados possam perseguir, lutar e dar o seu melhor. Digo isso porque hoje a empresa tem como acionistas fortes grupos de Private Equity onde os indicadores financeiros são o principal e único foco e nenhum empregado vai "amar" e "dar o seu melhor" para uma empresa onde o foco principal é o dinheiro. Todo ser humano precisa mais que isso e, na minha visão, esse será o principal desafio dos atuais administradores.

[...] Meus projetos para o futuro... boa questão a ser respondida e depois de muitos e muitos anos atuando no mundo corporativo tenho analisado e estudado outras oportunidades no campo do trabalho voluntário, ajuda ao 
próximo a como atuar para termos um Brasil melhor, mais fraterno e mais justo. (Juarez)

\section{Processo Dissociativo por Descomprometimento}

Valéria tinha uma expectativa positiva em relação a privatização, no entanto, foi surpreendida com a maneira como o processo de downsizing foi conduzido.

[...] muitos de nós, via a privatização também como um risco, mas também, como uma oportunidade de a empresa melhorar. [...] [Entrevistadora: O que teve mais impacto o anúncio da privatização ou o anúncio do PDO?] Anúncio do PDO, com certeza! Porque do nosso ponto de vista, privatizar não, necessariamente, teria que acontecer o que aconteceu com relação as pessoas, [...] não dessa forma tão traumática. (Valéria)

Para Valéria o principal problema no processo de privatização, aparentemente, foi a maneira como os empregados foram tratados "eles machucaram tanto as pessoas que agora nem com uma proposta melhor, as pessoas estão querendo ficar". Ela vivenciou o início do processo com uma expectativa positiva que se converteu em surpresa e tristeza, culminando, ao fim, em mágoa.

Valéria percebia a BR como uma empresa que valorizava os seus empregados e, aparentemente, não esperava que um eventual processo de downsizing fosse conduzido de forma "tão traumática", quer dizer, sem transparência e descuidada com os empregados, "Foram 15 dias que eu não recebia um e-mail, não recebia nada, nenhuma decisão, nada acontecia, as pessoas ficaram chocadas! As pessoas chorando nos corredores, [...]".

Além disso, Valéria destaca em todo o seu depoimento o seu comprometimento, empenho e resultados, por isso, ela esperava que a administração da BR lhe garantisse um tratamento mais cuidadoso. No entanto, o processo de downsizing, na percepção dela, foi apenas quantitativo, tratou com os empregados como números a serem reduzidos.

Eles poderiam ter tentado sim fazer uma redução, propor algumas coisas, fazer alguns cortes porque sim, poderia ter muita gente que tava ali e poderia não estar contribuindo muito com a empresa, então eles poderiam ter feito muitas coisas diferentes [...] eles erraram muito [Entrevistadora: um processo mais qualitativo?] Exatamente, um processo mais qualitativo e não foi nada qualitativo. Tanto que depois, eles começaram a perceber o que tinham feito e tentaram corrigir, mas já era tarde, inclusive, comigo, particularmente, aconteceu isso. (Valéria) 
Assim, o processo de dissociação de Valéria da IO passou por uma quebra de expectativa com relação ao tratamento que ela esperava receber da $\mathrm{BR}$, isto é, o reconhecimento do seu bom trabalho e, também, em relação ao tratamento dado aos colegas. Essa quebra de expectativa configura-se em uma perda, a IO que suscitava a confiança de Valéria não existe mais.

Ademais, é importante atentar para o fato de que Valéria estava em uma situação financeira confortável, segundo o seu depoimento, o que a ajudou a tomar a decisão de aderir ao PDO. Entretanto, a mágoa, resultante da quebra de expectativa, corroborou para a decisão, o que ficou perceptível quando ela relatou que recebeu uma proposta para que ficasse, mas já era tarde, ela já havia decidido. Esse processo dissociativo foi nomeado como descomprometimento, pois havia um comprometimento por parte de Valéria em relação a BR que foi quebrado em razão da falta de reciprocidade e reconhecimento por parte da administração da BR, que pelo contrário, a machucou. "Então, assim, eles perceberam depois que tinham errado, mas aí já era tarde". (Valéria). O principal sentido que foi possível depreender do depoimento de Valéria é de que a BR não agiu com justiça.

\section{Processo Dissociativo por Desidentificação}

As descrições de Mauro e Caio a respeito do fim da IO foram as que mais se aproximaram de descrições de perda como morte. E, eles se sentiram como parte da IO que morreu.

Eles queriam fazer um rompimento total da companhia, parecia que 'eu quero daqui pra frente, eu não quero nada pra trás'. Aí começou um processo forte de pressão [...] de um terrorismo [...] de dizer que 'ou vocês aderem ao PDV [PDO] ou não tem como garantir o emprego, quem ficar vai ser cortado pela metade'. Algo que não deu tempo de se pensar, algo [...] 'vamos descartar o passado que não me interessa e abrir para a companhia valer mais com o novo'. [...] foi um estresse porque foi uma máquina de moer gente aquele processo.

Foi feito da pior maneira possível, sem nenhum respeito com o funcionário. Agora foi tudo pensado, não foi nada de amador. [...] (Mauro)

Mauro e Caio já esperavam pela privatização e perceberam todo o processo como doloroso, "uma máquina de moer gente aquele processo" (Mauro). Eles vivenciaram um processo de ruptura identitária em relação a BR que foi categorizado como um processo dissociativo de desidentificação, pois eles não se 
identificam com a nova IO, isto é, os atributos da nova IO são inconciliáveis com as suas identidades e projetos pessoais.

Quem ficou [...] sem nenhuma perspectiva, sem nenhuma identidade porque a empresa não tem identidade [...]. Uma empresa sem ter uma cara, como trabalhar, como se comportar, como se relacionar com empregados e com o público em geral. (Mauro).

[...] não me sinto fazendo parte desse modelo de empresa [...]. Depois de um determinado tempo confortável com o que você é, o seu espírito, a sua alma é uma opção que não tem quase alternativa [...] você começa a pensar na sua existência como ser humano (Caio).

Além disso, ambos relataram o sentimento de perda intensa.

Eu tenho uma história de vida que eu deixei pra trás, deixei sem querer deixar [...]. A gente ficou [...] sentindo que tivesse entregado uma parte [...]" (Mauro).

Eu até comentei com a equipe 'todos nós vamos viver um luto, é um luto'. A gente viveu um periodo de luto, ali morreu sonhos, morria a relação que você tinha com aquela empresa, a nossa empresa morreu, a BR morreu" (Caio).

Durante o processo, Mauro experimentou sentimentos intensos como de terror e tristeza. Ao final, os sentimentos que restaram foram de desolação, tristeza e mágoa.

Eu recebi umas fotos do nosso lugar meio triste, vazio pra ser vendido. Já foi desocupado [...] aquela nostalgia de 'que pena' [...] um lugar vazio com buraco no teto, combina com o sentimento de desolação de quem saiu [...]. (Mauro)

Caio que encarou conscientemente o processo como um luto, por outro lado, chegou ao final com um sentimento de introspecção e engajado em um trabalho consciente de identidade. "A grande maioria tá passando por um período de adaptação a vida e introspectivo no sentido de olhar pra si e ver qual é o caminho." (Caio)

Assim, a Figura 12 sistematiza os processos mobilizados pelos empregados para dar sentido ao fim da identidade organizacional. 
Figura 12 - Sensemaking em Resposta ao Fim da Identidade Organizacional

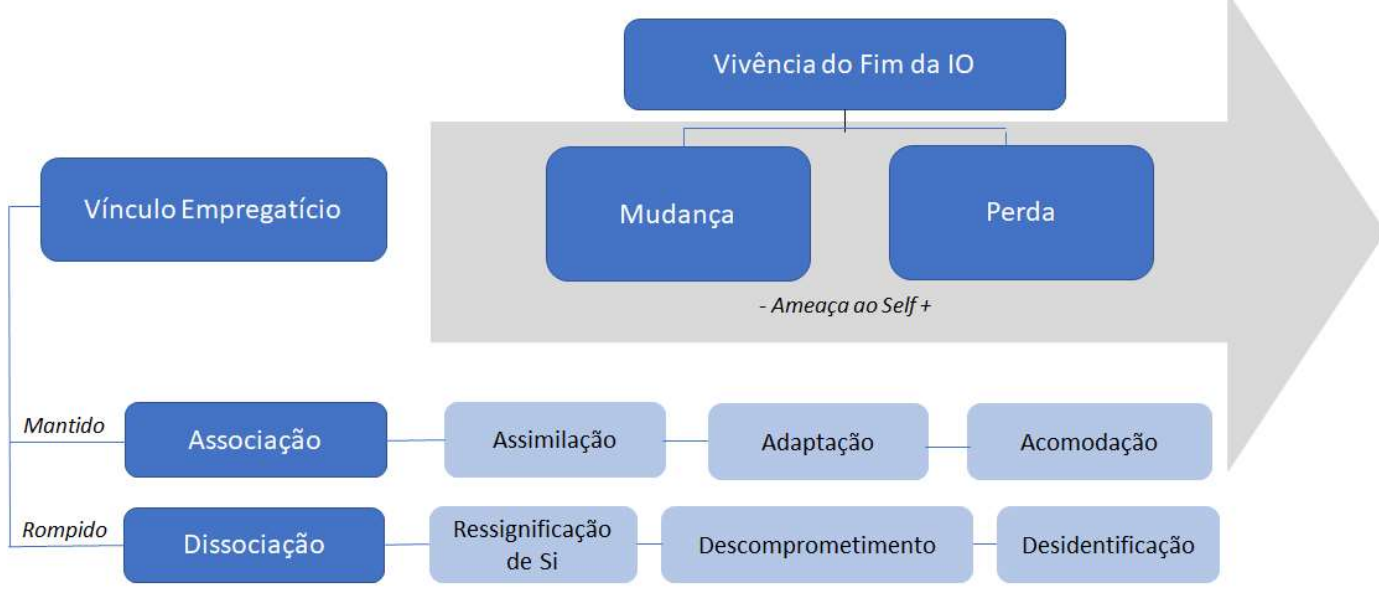

A decisão por manter ou romper o vínculo empregatício é a primeira ação a moldar a realidade, ela parece condicionar se o indivíduo se engajará em um processo associativo ou dissociativo. E, a intensidade de ameaça que o fim da IO representa para o self, parece definir o tipo de processo de associação ou dissociação mobilizado. A Figura 12 sintetiza os processos observados a partir da manutenção ou rompimento do vínculo empregatício e como a intensidade da ameaça influencia no tipo de processo e no sentido atribuído ao fim da IO, quer dizer, sentido de perda ou mudança. Isso posto, o Quadro 10 resume as principais diferenças entre os processos sociais identificados nos depoimentos.

Quadro 10 - Diferenças entre os Processos Sociais de Associação e Dissociação

\begin{tabular}{|l|l|l|l|}
\hline Ameaça ao Self & Processo Social & Experiência & $\begin{array}{l}\text { Sentidos } \\
\text { Resultantes }\end{array}$ \\
\hline Baixa & $\begin{array}{l}\text { Assimilação } \\
\text { Ressignificação de Si }\end{array}$ & Mudança & Oportunidade \\
\hline Média & $\begin{array}{l}\text { Adaptação } \\
\text { Descomprometimento }\end{array}$ & Perda & Arbitrariedade \\
\hline Alta & $\begin{array}{l}\text { Acomodação } \\
\text { Desidentificação }\end{array}$ & Perda & Morte \\
\hline
\end{tabular}

Quem se engajou nos processos de assimilação ou ressignificação de si vivenciou o fim da IO como uma mudança com o potencial de oferecer novas oportunidades dentro (assimilação) ou fora da BR (ressignificação de si), isto é, a mudança da IO foi encarada como uma oportunidade de mudanças positivas, também, para o self. 
Por outro lado, quem se engajou nos processos de adaptação ou descomprometimento vivenciou de forma traumática o fim da IO, como uma perda. Esses depoentes avaliaram que o comportamento da empresa com os empregados foi arbitrário, injusto. Em ambos os casos (adaptação e descomprometimento), permaneceu (guardadas as devidas proporções) um sentimento de ressentimento em relação a maneira como o processo de downsizing foi conduzido.

Já quem se engajou nos processos de acomodação ou desidentificação vivenciou o fim da IO como morte. No entanto, com o rompimento, os desidentificados puderam avançar em seu luto, enquanto que os acomodados não puderam realizar (materializar) o luto em sua completude e permanecem como se fossem condenados aguardando a execução, como os "cadáveres ambulantes" descritos por Gabriel (2012).

\subsection{Discussão dos resultados, achados e limitações}

A Figura 12 sistematiza os processos mobilizados pelos empregados para dar sentido ao fim da IO com destaque para duas variáveis, a decisão por manter ou romper o vínculo com a empresa, que passa, também, por um cálculo de prioridades, e a intensidade da ameaça ao self. Os resultados reforçam que as decisões tomadas e as emoções (decorrente da ameaça ao self) moldam a própria realidade a qual os indivíduos estão dando sentido. Quer dizer, conforme o processo social mobilizado, os indivíduos constituirão os sentidos para o fim da IO. E, o processo mobilizado terá como objetivo a proteção do self, seja reforçando o vínculo identitário (caso dos processos associativos), seja separando a IO do self (caso dos processos dissociativos). Assim, quanto mais intensa a $\mathrm{IdO}$, maior a ameaça percebida e por consequente, mais complexo é o trabalho identitário, quer dizer, mais complexo é manter-se vinculado ou separar a IO do self.

Além do modelo de Sensemaking em Resposta ao Fim da Identidade Organizacional (Figura 12), esse estudo contribuiu com a elaboração de três novas subcategorias de processos sociais de dissociação, o descomprometimento, a desidentificação e a ressignificação de si. Os resultados demonstraram como os processos sociais impactam no sensemaking, além de apontar que as práticas organizacionais podem influenciar nesses processos sociais e, por consequência, no sensemaking. Quer dizer, as organizações podem optar por estratégias que minimizem a intensidade de ameaça ao self, levando a uma maior quantidade de 
empregados satisfeitos (associados por assimilação) e evitando que os empregados que optarem por permanecer se sintam condenados (associados por acomodação). E, mesmo nos casos de ruptura do vínculo empregatício, é possível, também, tornar o processo menos doloroso. Todavia, tais práticas não foram diretamente analisadas neste estudo e carecem de investigação, inclusive, com um maior número de entrevistados. 


\section{Considerações Finais}

\section{Como os empregados dão sentido a eventos organizacionais traumáticos?}

A Figura 13 resume como os empregados dão sentido a eventos organizacionais traumáticos por meio das conexões entre identidade organizacional, identificação organizacional e a identidade do indivíduo/self, principalmente, no que se refere a identidade de membro - isto é, a parte da identidade do indivíduo derivada da associação com a identidade organizacional.

Figura 13 - Eventos Organizacionais Traumáticos e Sentido: Resultados dos Três Estudos

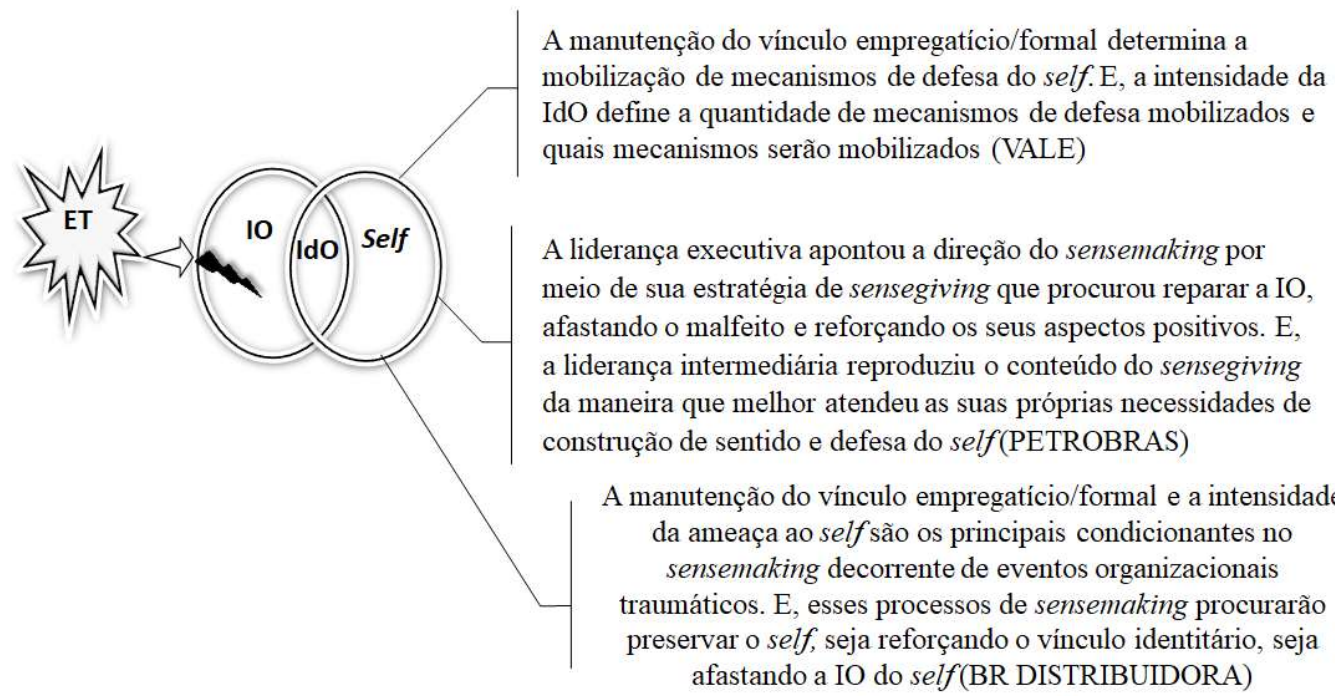

De acordo com os resultados dos três estudos, no sensemaking decorrente de eventos organizacionais traumáticos, uma das primeiras ações que irá constituir a realidade a qual os empregados estão procurando dar sentido, inclusive, por meio da própria ação, é a decisão por manter ou não o vínculo empregatício/formal.

Ao manter o vínculo, o empregado tentará reforçar uma construção positiva do seu self procurando, ao mesmo tempo, preservar a IO como autorreferência. E, para tanto, a depender do tipo de evento traumático, algumas possibilidades foram identificadas nos estudos, a saber: i) ressignificar o evento traumático tornando-o menos ameaçador ao self por meio da mobilização de mecanismos de defesa da IO, quando não for possível desassociar o evento da IO (caso da Vale); ii) reparar a IO por meio de estratégias discursivas que reforcem as bases de uma construção positiva de self, além de afastar a ameaça da IO (caso Petrobras); e iii) engajar em processos sociais de associação com vistas a manter IO como referência para o self 
por meio de negociações - que podem ser mais superficiais, como na acomodação e na adaptação ou mais profundas, como na assimilação - para lidar com os estremecimentos na IdO provocados quando o evento traumático for o próprio fim da IO como se conhecia (caso BR Distribuidora).

Além disso, é importante destacar que a intensidade da IdO e da ameaça ao self parecem coincidir, quer dizer, quanto mais intensa a $\mathrm{IdO}$, maior a intensidade da ameaça ao self. No entanto, a intensidade da ameaça ao self influi de maneira diferente nas repostas defensivas da $\mathrm{IO}$ e nos processos sociais de associação. No caso dos mecanismos de defesa, quanto mais intensa a ameaça, mais mecanismos são mobilizados e mais intensos são eles. Já no caso dos processos sociais de associação, quanto mais intensa a ameaça ao self, mais frágeis são os processos mobilizados, ou seja, mais superficial é o tipo de associação promovida.

Nesse sentido, os resultados do Estudo 3 avançam em relação ao Estudo 1, pois para além das variáveis determinantes que influem no sensemaking, ele esclarece como os empregados procuram preservar o seu self, seja preservando o vínculo identitário ou separando a IO do self por meio do sensemaking.

Assim, ao decidir por romper com o vínculo empregatício/formal, o exempregados não mobilizaram mecanismos de defesa da IO, independentemente, da intensidade da $\mathrm{IdO}$ antes da ruptura. E, isso ocorreu, provavelmente, porque a quebra do vínculo empregatício/formal promoveu certo afastamento do self em relação a IO e, por consequência, afastou a ameaça. Já nos casos do Estudo 3, em que os processos sociais que constam no sensemaking foram analisados, foi possível verificar que o tipo de processo de dissociação, também, é influenciado pela intensidade da ameaça ao self. Em outras palavras, quanto mais intensa é a ameaça ao self, mais intenso é o processo social de dissociação, ou seja, mais profunda é a separação da IO do self.

\section{Contribuições Teóricas e Praticas}

A principal contribuição teórica desta tese é possibilitar uma melhor compreensão das interconexões entre as variáveis relevantes no sensemaking decorrente de eventos organizacionais traumáticos (a identidade organizacional, a identificação organizacional e o self) por meio da proposição de três modelos analíticos (a Figura 2, a Figura 11 e a Figura 12). Isso posto, destacam-se os modelos propostos no Estudos 2 e 3 (Figura 11 e 12, respectivamente) que possuem 
uma abordagem processual que é mais adequada a compreensão do fenômeno/perspectiva do sensemaking. Ademais, novas categorias também foram elaboradas: a reação defensiva da IO nomeada vitimização no Estudo 1; as fases ou etapas do processo de enfrentamento das crises éticas pelas lideranças intermediárias, isto é, Choque Traumático, Fratura na Identidade Organizacional e Reparação Identitária no Estudo 2; e os Processos dissociativos de enfrentamento: o Descomprometimento, a Desidentificação e a Ressignificação de si no Estudo 3

Outrossim, esta tese contribui ao lançar luz sobre as respostas e processos mais satisfatórios, tanto da perspectiva da gestão, quanto da perspectiva dos empregados e da sociedade. No caso da Vale, por exemplo, não é possível desassociar o evento traumático da IO porque o malfeito está diretamente ligado ao core business e não pode ser desfeito, já que vidas foram perdidas, além dos danos ao meio ambiente. Além disso, ainda que algumas pessoas possam ser diretamente responsabilizadas, não há como circunscrever a mácula e depurar a IO. Então, é melhor que os empregados se engajem no mecanismo de distinção positiva baseado em medidas reparadoras adotadas pela empresa do que em divisão ou negação, por exemplo. E, como visto no caso da Petrobras, a liderança pode adotar uma estratégia de sensegiving apoiada em medidas reparadoras e elementos discursivos a fim de reparar a IO e que leve a distinção positiva como resposta a ameaça. Nesse sentido, o modelo proposto no Estudo 2, inclusive, é o mais contribuitivo do ponto de vista da gestão.

Por fim, o Estudo 3 demonstra que em uma mudança, potencialmente, traumática, como é o fim da IO, a organização deve ser, especialmente, responsável e respeitosa com os seus empregados e não tornar a experiência ainda mais desagradável. E o mínimo a se fazer para isso, já que o processo é difícil de todo modo, é ter uma boa estratégia de comunicação e política de recursos humanos. Em outras palavras, é necessária maior transparência ao longo do processo para que as pessoas tenham a oportunidade de tomar decisões mais conscientes. Além disso, é importante adotar uma política de recursos humanos que acolha as pessoas que passaram pelo processo e permaneceram na organização, que possibilite a elas oportunidades e novas perspectivas na empresa.

Assim, promover respostas e processos mais satisfatórios para os empregados é, também, o melhor a fazer sob o ponto de vista da gestão, haja vista que tais 
processos podem ser associados ao chamado crescimento individual póstraumático, relacionado nas pesquisas, à força pessoal, à melhora no relacionamento com os outros e à abertura a novas possibilidades, por exemplo, e, no trabalho, à pró atividade, à liderança pro-social, dentre outras mudanças psicológicas e comportamentais positivas (MAITLIS, 2020).

\section{Limitações}

Esta tese se concentra nas reações dos empregados a crises/traumas organizacionais e apresenta três estudos independentes com perguntas, metodologias e análises específicas centradas nesta questão. Embora os três estudos tenham sido orientados para a produção de sentido em situações de trauma organizacional, as inserções foram realizadas em diferentes empresas, momentos e contextos. Por esta razão, não é possível, nem foi a intensão da autora deste trabalho propor uma articulação entre os achados observados em cada estudo.

\section{Estudos Futuros}

Como ficou demonstrado, por mais difícil que seja lidar com eventos organizacionais traumáticos, é possível superá-los ou, ao menos, minimizar os seus efeitos. Deste modo, acredita-se que os seguintes pontos são interessantes de serem explorados em estudos futuros:

- Os processos que estão sendo mobilizados pelos empregados da Vale para dar sentido ao desastre em Brumadinho, que ocorreu após o primeiro estudo desta tese, tendo em vista a reincidência da empresa nesse tipo de ocorrência, sendo neste caso a responsável direta por uma tragédia humana maior que o desastre de Mariana. Ademais, como a liderança executiva está reagindo a esse trauma? A empresa adotou alguma estratégia de sensegiving? Com que nível de sucesso? Quais são as diferenças na produção de sentido após o desastre de Mariana e após o desastre de Brumadinho?

- Aprofundar o estudo de estratégias de sensegiving adotadas por organizações que passaram por eventos organizacionais traumáticos e analisar quais práticas são mais ou menos recomendadas, além de verificar se modelo proposto no Estudo 2 se confirma em outros casos, isto é, se o 
uso de narrativas e enquadramentos auxilia no enfrentamento do evento traumático pelos empregados;

- Estudos longitudinais comparando os comportamentos dos (ex)empregados que passaram por eventos organizacionais traumáticos e se engajaram em processos sociais de associação e de dissociação para melhor compreender como esses processos são disparados, mediados e a sua resolução. 


\section{Referências}

AÇÕES Anticorrupção. $[S . \quad$ l. $]$ : Petrobras, 2018. Disponível em: https://www.youtube.com/watch?v=ktfyydQIGPk\&list=PLJGZ8X1mZTR1e6swx_BzdaHov9oLurY0\&index=1. Acesso em: 23 mar. 2021.

ALBERT, S.; ASHFORTH, B. E; DUTTON, J.E. Organizational Identity and Identification: Charting New Waters and Building New Bridges. The Academy of Management Review, [S. l.], p. 13-17, 2000.

ALEXANDER, Benjamin N.; GREENBAUM, Bruce E.; SHANI, Abraham B. (Rami); MITKI, Yoram; HORESH, Arik. Organizational Posttraumatic Growth: Thriving After Adversity. The Journal of Applied Behavioral Science, [s. l.], p. 1-27, $2020 . \quad$ DOI $\quad$ DOI: $\quad 10.1177 / 0021886320931119$ journals.sagepub.com/home/jabs. Disponível em: https://journals.sagepub.com/doi/full/10.1177/0021886320931119. Acesso em: 17 set. 2020 .

ALEXANDER, C. R.; COHEN, M. A. Novas evidências sobre as origens do crime corporativo. Managerial and Decision Economics, [S. l.], v. 17, p. 421-435, 1996. DOI https://doi.org/10.1002/(SICI)1099-1468(199607)17:4<421::AIDMDE771>3.0.CO;2-U. Disponível em: https://onlinelibrary.wiley.com/doi/abs/10.1002/(SICI)10991468(199607)17:4\%3C421::AID-MDE771\%3E3.0.CO;2-U. Acesso em: 8 set. 2019 .

ALLARD-POESI, Florence. The Paradox of Sensemaking in Organizational Analysis. Organization, $[s . \quad l],$.$\quad v. 12, n. 2, p. 169-196, 2005. DOI$ $10.1177 / 1350508405051187$.

Disponível

em: https://www.researchgate.net/publication/247746871. Acesso em: 3 mar. 2021.

ANAND, V.; ELLSTRAND, A.; RAJAGOPALAN, A.; JOSHI, M. Organizational responses to allegations of corporate corruption. In: BURKE, R. J.; COOPER, C.

L. Research companion to crime and corruption in organizations. London, England: Edward Elgar, 2009. cap. 10, p. 217-230.

ARMAN, Rebecka. Death metaphors and factory closure. Culture and Organization, [s.l.], v. 20, n. 1, p. 23-39, 2014. DOI 10.13140/2.1.1723.6161. Disponível em: https://www.researchgate.net/publication/265490378_Organizational_death_and_ 
employee_motivation_Investigating_a_plant_closure_in_a_multi-

plant_organization. Acesso em: 18 set. 2020.

ASHFORTH, B.E.; HARRISON, S.H.; CORLEY, K.G. Identification in Organizations: An Examination of Four Fundamental Questions. Journal of Management, [S. l.], p. 325-374, 2008. DOI doi:10.1177/0149206308316059. Disponível em:

https://journals-sagepubcom.ez370.periodicos.capes.gov.br/doi/abs/10.1177/0149206308316059. Acesso em: 8 set. 2019.

AZEVEDO, C. da S. et al. Rationalization and sensemaking in care management: an experience of change in a hospital of the SUS (Unified Health System). Ciência \& Saúde Coletiva, [s. l.], v. 22, ed. 6, p. 1991 - 2002, 2017. DOI https://doi.org/10.1590/1413-81232017226.13312016. Disponível em: https://www.scielosp.org/article/csc/2017.v22n6/1991-2002/en/. Acesso em: 29 jan. 2021.

BARRY, D.; ELMES, M. On Paradigms and Narratives: Barry and Elmes 'Response. Academy of Management, [s. l.], v. 22, n. 4, p. 847-849, 1997. Disponível em: https://www.jstor.org/stable/259244?seq=1\#metadata_info_tab_contents. Acesso em: 23 mar. 2021.

BELL, EMMA. Ways of seeing organisational death: a critical semiotic analysis of organisational memorialisation. Visual Studies, [s. l.], v. 27, n. 1, p. 4-17, 2012. DOI 10.1080 / 1472586X.2012.642954. Disponível em: https://www.researchgate.net/publication/233349415_Ways_of_seeing_organisati onal_death_a_critical_semiotic_analysis_of_organisational_memorialisation. Acesso em: 18 set. 2020.

BELL, Emma; TAYLOR, Scott. Beyond letting go and moving on : new perspectives on organizational death, loss and grief. Scandinavian Journal of Management, $[s . \quad l],$.$\quad v. 27, \quad$ n. 1, p. 1-10, 2011. DOI $10.1016 /$ j.scaman.2010.09.013. Disponível em: https://www.researchgate.net/publication/227422216_Beyond_letting_go_and_m oving_on_New_perspectives_on_organizational_death_loss_and_grief. Acesso em: 18 set. 2020 . 
BERGER, Peter L.; BERGER, Brigitte. Socialização: como ser um membro da sociedade. In: FORACCHI, M. M.; MARTINS, J. Sociologia e sociedade: leituras de introdução à sociologia. [S. l.]: LTC, 1977. cap. 13, p. 200-214. BERGER, Peter L.; LUCKMANN, Thomas. The Social Construction of Reality. [S. l.]: Penguin Books, 1966. 249 p. Disponível em: http://perflensburg.se/Berger\%20social-construction-of-reality.pdf. Acesso em: 21 set. 2020 .

BR DISTRIBUIDORA. Nossa História: CONFIRA OS PRINCIPAIS MOMENTOS DA HISTÓRIA DA PETROBRAS DISTRIBUIDORA. [S. l.], [s.d]. Disponível em: https://br.com.br/pc/a-br-distribuidora/historia. Acesso em: 14 jan. 2021.

BR DISTRIBUIDORA. Relações com Investidores: Perfil Corporativo. [S. l.], [s.d]. Disponível em: https://ri.br.com.br/petrobras-distribuidora/perfilcorporativo/. Acesso em: 14 jan. 2021.

BREWER, M.B. The social self: On being the same and different at the same time. Personality and Social Psychology Bulletin, [s. l.], v. 17, n. 5, p. 475-482, 1991. DOI https://doi.org/10.1177/0146167291175001. Disponível em: https://psycnet.apa.org/record/1992-09052-001. Acesso em: 17 set. 2020.

BROWN, Andrew D. Identity Work and Organizational Identification. International Journal of Management Reviews, [s. l.], v. 19, n. 3, p. 296-317, 2017. DOI https://doi.org/10.1111/ijmr.12152. Disponível em: https://onlinelibrary.wiley.com/doi/10.1111/ijmr.12152. Acesso em: 17 set. 2020. BROWN, Andrew D.; COLVILLE, Ian; PYE, Annie. Making Sense of Sensemaking in Organization Studies. Organization Studies, [s. l.], p. 1-26, 2014. DOI $\quad 10.1177 \quad / \quad 0170840614559259 . \quad$ Disponível em: https://www.researchgate.net/publication/269405402_Making_Sense_of_Sensema king_in_Organization_Studies. Acesso em: 17 set. 2020.

BUNDY, J.; SHROPSHIRE, C.; BUCHHOLTZ, A.K. Strategic cognition and issue salience: Toward an explanation of firm responsiveness to stakeholder concerns. Academy of Management Review, [S. l.], p. 352-376, 2013.

CALHOUN, Lawrence G.; TEDESCHI, Richard G.; CANN, Arnie; HANKS, Emily A. Positive Outcomes Following bereavement: Paths to posttraumatic Growth. Psychologica Belgica, $[s . \quad$ l. $]$, v. 50, p. 125-143, 2010. DOI http://dx.doi.org/10.5334/pb-50-1-2-125.

Disponível em: 
https://www.psychologytoday.com/sites/default/files/attachments/128570/belgica. pdf. Acesso em: 17 set. 2020.

CARVALHO, V. D.; BORGES, L. O.; RÊGO, D. P. Interacionismo Simbólico: Origens, Pressupostos e Contribuições aos Estudos em Psicologia Social. Psicologia Ciência e Profissão, [s. l.], v. 30, n. 1, p. 146-161, 2010. DOI http://dx.doi.org/10.1590/S1414-98932010000100011. Disponível em: https://www.scielo.br/scielo.php?pid=S141498932010000100011\&script=sci_abstract\&tlng=pt\#: :text $=\mathrm{O} \% 20$ estudo\%20abor $\mathrm{da} \% 20 \mathrm{a} \% 20$ perspectiva,pensadores $\% 20$ reconhecidos $\% 20$ como $\% 20$ precursores $\%$ 20dessa. Acesso em: 21 fev. 2021.

CAUGHRON, Jay J.; MUMFORD, Michael D. Embedded leadership: How do a leader's superiors impact middle-management performance?. The Leadership Quarterly, $\quad[s . \quad$ l. $], \quad$ v. $\quad 23, \quad$ n. $\quad 3, \quad$ p. 342-353, 2012. DOI https://doi.org/10.1016/j.leaqua.2011.08.008. Disponível em: https:/www.sciencedirect.com/science/article/pii/S1048984311001317?via\%3Dih ub. Acesso em: 21 set. 2020.

COOREN ET AL. Communication, Organizing and Organization: An Overview and Introduction to the Special issue. Organization Studies, [S. l.], p. 1149-1170, 2011.

CORLEY, Kevin G.; GIOIA, Dennis A. Identity Ambiguity and Change in the Wake of a Corporate Spin-Off. Administrative Science Quarterly, [s. l.], v. 49, n. 2, p. 173-208, 2004. DOI 10.2307 / 4131471. Disponível em: https://www.researchgate.net/publication/258126203_Identity_Ambiguity_and_C hange_in_the_Wake_of_a_Corporate_Spin-Off. Acesso em: 19 set. 2020. CRAMER, P. Identity, Narcissism, and Defence Mechanisms in Late Adolescence. Journal of Research in Personality, [S. l.], p. 341-361, 1995.CRAMER, P. Ego functions and ego development: Defense mechanisms and intelligence as predictors ofego level. Journal of Personality, [S. l.], p. 735-760, 1999.

CROSINA, ELIANA; PRATT, MICHAEL G. TOWARD A MODEL OF ORGANIZATIONAL MOURNING: THE CASE OF FORMER LEHMAN BROTHERS BANKERS. Academy of Management Journal, [s. l.], v. 62, n. 1, p. 66-98, 2019. DOI https://doi.org/10.5465/amj.2017.0140. Disponível em: https://journals.aom.org/doi/abs/10.5465/amj.2017.0140. Acesso em: 17 set. 2020. 
CUNNINGHAM, J. Barton. Feelings and interpretations during an organization's death. Journal of Organizational Change Management, [s. l.], v. 10, n. 6, p. 471490, 1997.

\#DAQUIPRAFRENTE. $[S . \quad$ l. $]$ : Petrobras, 2015. Disponível em: https://www.youtube.com/watch?v=ySYxolFLoMc\&list=PLJGZ8X1mZTR_PDU EBQSGN47KWCT6EvYR9. Acesso em: 23 mar. 2021.

DAVIS, Christopher G.; WOHL, Michael J. A.; VERBERG, Norine. Profiles of Posttraumatic Growth Following an Unjust Loss. Death Studies, [s. l.], v. 31, n. 8, p. 693-712, 2007. DOI https://doi.org/10.1080/07481180701490578. Disponível em: https://www.tandfonline.com/doi/full/10.1080/07481180701490578. Acesso em: 21 set. 2020 .

DEGN, Lise. Sensemaking, sensegiving and strategic management in Danish higher education. High Educ, [s. l.], v. 69, p. 901-913, 2015. DOI $10.1007 /$ s10734-014-9812-3. Disponível em: https://www.researchgate.net/publication/276153214_Sensemaking_sensegiving_ and_strategic_management_in_Danish_higher_education. Acesso em: 19 set. 2020 .

DUTTON, J.E.; DUKERICH, J.M.; HARQUAIL, C.V. Organizational Images and Member Identification. Administrative Science Quarterly, [s. l.], v. 39, p. 239263, 1994. DOI http://dx.doi.org/10.2307/2393235. Disponível em: https://www.scirp.org/(S(351jmbntvnsjt1aadkposzje))/reference/ReferencesPapers .aspx?ReferenceID=1907775. Acesso em: 17 set. 2020 .

EBERLE, A. D.; CASALI, A. Crise organizacional e sensemaking: o caso de um hospital público no contexto da pandemia de influenza A (H1N1). Cadernos Ebape, [S. l.], p. 820-840, 2012.

ELO, Satu; KÄÄRIÄINEN, Maria; KANSTE, Outi; PÖLKKI, Tarja; UTRIAINEN, Kati; KYNGÄS, Helvi. Qualitative Content Analysis: A Focus on Trustworthiness. SAGE Open, $\quad[s . \quad l],$.$\quad p. 1-10, \quad 2014 . \quad$ DOI https://doi.org/10.1177/2158244014522633. Disponível em: https://journals.sagepub.com/doi/full/10.1177/2158244014522633. Acesso em: 11 dez. 2020.

ELSBACH, Kimberly D.; KRAMER, Roderick M. Members 'Responses to Organizational Identity Threats: Encountering and Countering the Business Week Rankings. Administrative Science Quarterly, [s. l.], v. 41, p. 442-476, 1996. DOI 
10.2307

2393938.

Disponível

em:

https://www.researchgate.net/publication/271806117_Members'_Responses_to_O rganizational_Identity_Threats_Encountering_and_Countering_the_Business_We ek_Rankings. Acesso em: 17 set. 2020.

ERIKSON, E. Identidade, juventude e crise. 2. ed. Rio de Janeiro: Zahar, 1976.

FAIRHURST, Gail; GRANT, David. The Social Construction of Leadership: A Sailing Guide. Management Communication Quarterly, [s. l.], v. 24, n. 2, p. 171210, 2010. DOI 10.1177/0893318909359697. Disponível em: https://www.researchgate.net/publication/247741887_The_Social_Construction_o f_Leadership_A_Sailing_Guide. Acesso em: 19 set. 2020.

FGV CPDOC. Companhia Vale do Rio Doce (Vale). [S. l.], 2009. Disponível em: http://www.fgv.br/cpdoc/acervo/dicionarios/verbete-tematico/companhia-vale-dorio-doce-cvrd. Acesso em: 13 jan. 2021.

FGV CPDOC. Petrobras. $\quad[S . \quad$ l. $], \quad[$ s.d]. Disponível em: http://www.fgv.br/cpdoc/acervo/dicionarios/verbete-tematico/petrobras-1. Acesso em: 14 jan. 2021.

FONSECA, Pedro C. D. Vargas: o capitalismo em construção 1906-1954. São Paulo: Brasiliense, 1987.

ESTADÃO. Privatizada, BR Distribuidora mantém nome Petrobrás e investe R\$ 1 bi. In: IstoéDinheiro. $\quad\left[\begin{array}{lllll}S . & l .\end{array}, \quad 5\right.$ mar. 2020. Disponível em: https:/www.istoedinheiro.com.br/privatizada-br-distribuidora-mantem-nomepetrobras-e-investe-r-1-bi/. Acesso em: 14 jan. 2021.

FERREIRA, E. C. do Val; FANDIÑO, A. M.; SEGRE, L.; NASCIMENTO, R. P. Privatização e mudanças organizacionais: um estudo de caso sobre transformação cultural e comportamental. Cadernos EBAPE.BR, Rio de Janeiro, v. 8, p. 468491, 2010. Disponível em: https://www.scielo.br/pdf/cebape/v8n3/a07v8n3.pdf. Acesso em: 3 nov. 2020.

FINE, G. A. O Triste Espólio, o misterioso Desaparecimento e o Glorioso Triunfo do Interacionismo Simbólico. RAE, [s. l.], p. 87 - 105, 2005. Disponível em: file://C:/Users/suzia/Downloads/37309-Texto\%20do\%20Artigo-73625-2-1020160518.pdf. Acesso em: 21 fev. 2021.

FIOL, C. Marlene. Capitalizing on Paradox: The Role of Language in Transforming Organizational Identities. Organization Science, [s. l.], v. 13, n. 6, p. 653-666, 2002. DOI https://doi.org/10.1287/orsc.13.6.653.502. Disponível em: 
https://pubsonline.informs.org/doi/10.1287/orsc.13.6.653.502. Acesso em: 18 set. 2020.

FRIEDRICH, Elmar; WÜSTENHAGEN, Rolf. Leading Organizations Through the Stages of Grief: The Development of Negative Emotions Over Environmental Change. Business \& Society, [s. l.], v. 56, n. 2, p. 186 - 213, 2017. DOI 10.1177/0007650315576151. Disponível em: https://www.researchgate.net/publication/277569276_Leading_Organizations_Thr ough_the_Stages_of_Grief_The_Development_of_Negative_Emotions_Over_En vironmental_Change. Acesso em: 18 set. 2020.

GABRIEL, Yiannis. Organizations in a State of Darkness: Towards a Theory of Organizational Miasma. Organization Studies, [s. l.], v. 33, n. 9, p. 1137-1152, 2012.

GERSTROEM, Anna. Identity after death: how legacy organizational identity and death form each other. Management Research Review, [s. l.], v. 38, n. 1, p. 89123, 2015. DOI 10.1108 / MRR-11-2012-0251. Disponível em: https://www.researchgate.net/publication/271725420_Identity_after_death_How_1 egacy_organizational_identity_and_death_form_each_other. Acesso em: 18 set. 2020 .

GIOIA, D. A.; CHITTIPEDDI, K. Sensemaking and Sensegiving in strategic change initiation. Strategic Management Journal, [s. l.], v. 12, p. 433-448, 1991. Disponível

em: https://www.jstor.org/stable/2486479?seq=1\#metadata_info_tab_contents. Acesso em: 19 set. 2020.

GOLTZ, Sonia M. Organizational change: insights from Buddhism and Acceptance and Commitment Therapy(ACT). Journal of Management, Spirituality \& Religion, $\quad[s . \quad l],$.$\quad v. \quad 15, \quad$ n. $\quad 5, \quad$ p. $424-449, \quad 2018 . \quad$ DOI https://doi.org/10.1080/14766086.2018.1513857. Disponível em: https://www.tandfonline.com/doi/full/10.1080/14766086.2018.1513857. Acesso em: 19 set. 2020 .

GOVERNANÇA e Conformidade. [S. l.]: Petrobras, 2017. Disponível em: https://www.youtube.com/watch?v=gfyI67AibKk\&list=PLJGZ8X1mZTR3psCHPuhK3HV5wJy5XUXF. Acesso em: 23 mar. 2021. 
GOVERNO DE MINAS GERAIS. Circuito Liberdade. Memorial Minas Gerais Vale. [S. l.], 2017. Disponível em: http://www.circuitoliberdade.mg.gov.br/ptbr/espacos-br/memorial-minas-gerais-vale. Acesso em: 13 jan. 2021.

GOVINDARAJ, S; JAGGI, B. Market overreaction to product recall revisited-The case of Firestone Tires and the Ford Explorer. Review of Quantitative Finance \& Accounting, [S. l.], p. 31-54, 2004.

GREVE, HENRICH R.; PALMER, DONALD; POZNER, JO-ELLEN. Organizations Gone Wild: The Causes, Processes, and Consequences of Organizational Misconduct. The Academy of Management Annals, [s. l.], v. 4, n. 1, p. 53-107, 2010. Disponível em: https://www.researchgate.net/publication/233356005_Organizations_Gone_Wild_ The_Causes_Processes_and_Consequences_of_Organizational_Misconduct. Acesso em: 17 set. 2020.

GUIMARÃES, P. C. V.; ALVES, M. A. Narratives and Sensemaking of an Organizationally-Based Environmental Disaster. BAR: Brazilian Administration Review, [S. l.], p. 228-247, 2014.

HARRIS, Stanley G.; SUTTON, Robert I. Functions of parting ceremonies in dying organizations. Academy of management journal, Stanford University, v. 29, n. 1, p. 5-30, 1986. DOI https://doi.org/10.2307/255857. Disponível em: https://psycnet.apa.org/record/1986-18764-001. Acesso em: 19 set. 2020.

HARVEY, Jonh H. Perspectives on Loss and Trauma Assaults on the Self. London: SAGE, 2002. 317 p. ISBN 978-0761921615.

HATCH, Mary Jo; YANOW, Dvora. Organization theory as an interpretative science. In: THE OXFORD Handbook of Organization Theory. [S. l.: s. n.], 2009. cap. 2, p. 63-87.

HERSEL, M.C. et al. The Corrective Actions Organizations Pursue Following Misconduct: A Review and Research Agenda. Academy of Management Annals, [S. l.], p. 547-585, 2019.

HIRSCHBERGER, Gilad. Collective Trauma and the Social Construction of Meaning. Frontiers in Psychology, [s. l.], v. 9, n. 1441, p. 1-14, 2018. DOI https://doi.org/10.3389/fpsyg.2018.01441. Disponível em: https://www.frontiersin.org/articles/10.3389/fpsyg.2018.01441/full. Acesso em: 17 set. 2020 . 
HOFFMAN, A.J. Institutional Evolution and Change: Environmentalism and the US Chemical Industry. Academy of Management Journal, [S. l.], p. 351-371, 1999.

HSIEH, Hsiu-Fang; SHANNON, Sarah E. Three Approaches to Qualitative Content Analysis. Qualitative Health Research, [s. l.], p. 1277-88, 2005. DOI 10.1177/1049732305276687. Disponível em: https://www.researchgate.net/publication/7561647_Three_Approaches_to_Qualita tive_Content_Analysis. Acesso em: 9 dez. 2020.

INGRAM, D.; KRANSY, R. Johnson \& Johnson to pay \$2.2 billion to end U.S. drug probes. REUTERS, $\left[\begin{array}{ll}S . & l .\end{array}\right], 4$ nov. 2013. Disponível em: https://www.reuters.com/article/us-jnj-settlement/johnson-johnson-to-pay-2-2-

billion-to-end-u-s-drug-probes-idUSBRE9A30MM20131104. Acesso em: 9 set. 2019 .

JAMES, Erika H.; WOOTEN, Lynn P.; DUSHEK, Kelly. Crisis Management: Informing a New Leadership Research Agenda. The Academy of Management Annals, [s. l.], v. 5, n. 1, p. 455-493, 2011. DOI 10.1080/19416520.2011.589594. Disponível

em: https://www.researchgate.net/publication/232840593_Crisis_Management_Inform ing_a_New_Leadership_Research_Agenda. Acesso em: 19 set. 2020.

JOSHI, Mahendra; MCKENDALL, Marie. Responses to the Discovery of Unethical Acts: An Organizational Identity and Reputation Perspective. Business \& Society, $[s . \quad l],$.$\quad v. \quad 57, \quad$ n. $\quad 4, \quad$ p. $706-741, \quad 2018 . \quad$ DOI https://doi.org/10.1177/0007650315623953. Disponível em: https://journals.sagepub.com/doi/10.1177/0007650315623953. Acesso em: 19 set. 2020.

KAHN, Susan; LIEFOOGHE, Andreas. Thanatos: Freudian manifestations of death at work. Culture and Organization, [s. l.], v. 20, n. 1, p. 1-15, 2013. DOI 10.1080 / 14759551.2013.853064. Disponível em: https://www.researchgate.net/publication/259195714_Thanatos_Freudian_manife stations_of_death_at_work. Acesso em: 21 set. 2020.

KAUFFMAN, Jeffrey. Loss of the Assumptive World: A Theory of Traumatic Loss. [S. l.]: Psychology Press, 2002. 246 p. 
KAVILANZ, P. B. Mattel fined \$2.3 million over lead in toys. CNN MONEY, [ $S$. l.], p. 1-2, 5 jun. 2009. Disponível em: https://money.cnn.com/2009/06/05/news/companies/cpsc/. Acesso em: 9 set. 2019. KREINER, GLEN E.; HOLLENSBE, ELAINE C.; SHEEP, MATHEW L. WHERE IS THE "ME" AMONG THE "WE"? IDENTITY WORK AND THE SEARCH FOR OPTIMAL BALANCE. Academy of Management Journal, $[s$. l.], v. 49, n. 5, p. 1031-1057, 2006. DOI 10.2307 / 20159815. Disponível em: https://www.jstor.org/stable/20159815?seq=1\#metadata_info_tab_contents.

Acesso em: 17 set. 2020.

KÜBLER-ROSS, Elisabeth; KESSLER, David. On Grief and Grieving: Finding the Meaning of Grief Through the Five Stages of Loss. [S. l.]: Scribner, 2005.

LACAZ, F. A. de C.; PORTO, M. F. de S.; PINHEIRO, T. M. M. Tragédias brasileiras contemporâneas: o caso do rompimento da barragem de rejeitos de Fundão/Samarco. Revista Brasileira de Saúde Ocupacional, [S. l.], p. 1-12, 2017.

Disponível em: http://www.scielo.br/scielo.php?script=sci arttext\&pid=S030376572017000100302\&lng=pt\&tlng=pt. Acesso em: 3 set. 2019.

LAKATOS, Eva Maria. Sociologia Geral. [S. l.]: ATLAS SA, 1990. 324 p.

LANGLEY, Ann; TSOUKAS, Haridimos. Introducing. In: HERNES, Tor; MAITLIS, Sally. Process, Sensemaking, and Organizing. [S. l.: s. n.], 2010. cap. 1, p. 1-26. ISBN 9780199594566. Disponível em: https://oxford.universitypressscholarship.com/view/10.1093/acprof:oso/97801995 94566.001.0001/acprof-9780199594566-chapter-1. Acesso em: 17 set. 2020.

LEITE, E. L.; FERREIRA, A. S. S.; BATISTA, J. R. M.; ESTRAMIANA, J. L. A.; TORRES, A. R. R. Nacionalismo, Patriotismo e Essencialismo na Construção da Identidade Nacional Brasileira. Trends Psychol., [s. l.], v. 26, n. 4, p. 2063-2075, 2018. DOI http://dx.doi.org/10.9788/tp2018.4-13pt. Disponível em: https://www.scielo.br/scielo.php?script=sci_abstract\&pid=S235818832018000402063\&lng=en\&nrm=iso\&tlng=pt. Acesso em: 21 fev. 2021.

LORD, Robert G.; GATTI, Paola; CHUI, Susanna L.M. Social-cognitive, relational, and identity-based approaches to leadership. Organizational Behavior and Human Decision Processes, $[s$. l.], v. 136, p. 119-134, 2016. DOI https://doi.org/10.1016/j.obhdp.2016.03.001. Disponível em: https://psycnet.apa.org/record/2016-46083-013. Acesso em: 19 set. 2020. 
LOGEMANN, Minna; CORNELISSEN, Joep; REBECCA, Piekkari. The sense of it all: Framing and narratives in sensegiving about a strategic change. Long Range Planning, [s. l.], p. 1-17, 2018.

MACHADO-DA-SILVA, C.L.; NOGUEIRA, E.E. Identidade Organizacional: um Caso de Manutenção, Identidade Organizacional: um Caso de Manutenção, outro de Mudança. Revista Administração Contemporânea, [S. l.], p. 35-58, 2001.

MACLEAN, Mairi; HARVEY, Charles E.; CHIA, Robert. Sensemaking, storytelling and the legitimization of elite business career. Human Relations, $[s$. l.], v. 65, n. 1, p. 17-40, 2012. DOI 10.1177/0018726711425616. Disponível em: https://www.researchgate.net/publication/254097834_Sensemaking_storytelling_a nd

MAITLIS, Sally. The social processes of organizational sensemaking. The Academy of Management Journal, [s. l.], v. 48, n. 1, p. 21-49, 2005. DOI 10.2307 / 20159639. Disponível em: https://www.jstor.org/stable/20159639?seq=1\#metadata_info_tab_contents. Acesso em: 17 set. 2020.

MAITLIS, S. Posttraumatic Growth atWork. Annual Review of Organizational Psychology and Organizational Behavior, University of Oxford, United Kingdom, v. 7, p. 395-419, 2020. DOI https://doi.org/10.1146/annurev-orgpsych012119- 044932. Disponível em: www.annualreviews.org. Acesso em: 17 set. 2020 .

MAITLIS, S.; CHRISTIANSON, M. Sensemaking in Organizations: Taking Stock and Moving Forward. The Academy of Management Annals, [S. l.], p. 57-125, 2014.

MAITLIS, Sally; SONENSHEIN, Scott. Sensemaking in Crisis and Change: Inspiration and Insights from Weick (1988). Journal of Management Studies, Wiley Blackwell, v. 47, ed. 3, p. 551-580, 2010. DOI $10.1111 /$ j.14676486.2010.00908.x.

Disponível

em: https://ideas.repec.org/a/bla/jomstd/v47y2010i3p551-580.html. Acesso em: 17 set. 2020 .

MARTINS, L. C. dos P. Petróleo e "nacionalismo" no segundo Governo Vargas: o debate em torno da criação da Petrobras. Historiae, Rio Grande, v. 6, ed. 2, p. 401$425,2015$. 
MASSARIK, F. The Interviewing Process Re-Examined. In: REASON, Peter; ROWAN, John. Human Inquiry: A Source Book of New Paradigm Research. Chichester: Wiley, 1981. p. 201-206.

MCCRACKEN, Grant. The long interview: Qualitative research methods series. [S. l.]: A SAGE, 1988. v. 13.

MORGAN, Gareth. Paradigmas, metáforas e resolução de quebra-cabeças na teoria das organizações. RAE, [s. l.], v. 45, n. 1, p. 58-71, 2005.

PEARSON, C.M.; CLAIR, J.A. Reframing crisis management. Academy of Management, [S. l.], p. 59-76, 1998.

PEÑA, Pablo A.; VAN DEN BROUCKE, Stephan; LEYSEN, Jan; DE SOIR, Erik. Definitions, Typologies, and Processes Involved in Organizational Trauma: A Literature Review. Human Resources Management and Organizational Development, [s. l.], p. 1-17, 2017. DOI 10.4018/978-1-5225-2021-4.ch001. Disponível em: https://www.researchgate.net/publication/315657527_Definitions_Typologies_an d_Processes_Involved_in_Organizational_Trauma_A_Literature_Review. Acesso em: 18 set. 2020 .

PETIT, S. C.; HUAULT, I. From Practice-based Knowledge to the Practice of Research: Revisiting Constructivist Research Works on Knowledge. Management Learning, [s. l.], v. 39, p. 73 - 91, 2007. DOI 10.1177 / 1350507607085173.

Disponível em: https://www.researchgate.net/publication/46477609_From_Practicebased_Knowledge_to_the_Practice_of_Research_Revisiting_Constructivist_Rese arch_Works_on_Knowledge. Acesso em: 21 fev. 2021.

PETRIGLIERI, J.L. Under threat: responses to and the consequences of threats to individuals' identities. The Academy of Management Review, [S. l.], p. 641-662, 2011.

PETROBRAS. Petrobras 60 anos: Episódio 1: Trabalhar e aprender ao mesmo tempo. In: Petrobras 60 anos: Episódio 1: Trabalhar e aprender ao mesmo tempo. $[S . \quad$ l.], [2013]. Disponível em: https://www.youtube.com/watch?v=Wg_2FWQc62Q. Acesso em: 18 mar. 2021. POEGLER, N.A.; BISEL, R.S. The Role of Identification in Giving Sense to Unethical Organizational Behavior: Defending the Organization. Management Communication Quarterly, [S. l.], p. 155-183, 2013. 
SANTOS, R. A. S. dos; BANDEIRA-DE-MELLO, R.; CUNHA, C. J. C. de A. The Leadership Process During an Organizational Crisis. Journal of Operations and Supply Chain Management, [s. l.], p. 94-109, 2016.

SCHONBACH, P. Account epsodes: The management or escalation of conflict. [S. l.]: Cambridge University Press, 1990.

SCOTT, M. B.; LYMAN, S.M. Accounts. American Sociological Review, [S. l.], p. 46-62, 1968.

SCHUTZ, Alfred. Interpretação Social e Orientação Individual: I. A Concepção Social da Comunidade e do Indivíduo. In: WAGNER, Helmut R. (org.). Fenomenologia e Relações Sociais: Textos Escolhidos de Alfred Schutz. Rio de Janeiro: ZAHAR EDITORES, 1979. p. 79-85.

SILVA, J. R. G. da; VERGARA, S. C. Sentimentos, subjetividade e supostas resistências à mudança organizacional. RAE, [s. l.], v. 43, n. 3, p. 10-21, 2003.

SOBRAL, F.; CARVALHO, J.; ŁAGOWSKA, U.; FURTADO, L. M. G. P; GROBMAN, M. Melhor prevenir do que remediar: o sensemaking da liderança nos tempos da COVID-19. Revista de Administração Pública, [s. l.], p. 758-781, 2020. DOI http://dx.doi.org/10.1590/0034-761220200262. Disponível em: https://www.scielo.br/pdf/rap/v54n4/pt_1982-3134-rap-54-04-758.pdf. Acesso em: 15 jan. 2021.

STEIN, Mark. 'Fantasy of Fusion' as a Response to Trauma: European Leaders and the Origins of the Eurozone Crisis. Organization Studies, [s. l.], v. 37, n. 7, p. 919937, 2016. DOI https://doi.org/10.1177/0170840615622070. Disponível em: https://journals.sagepub.com/doi/10.1177/0170840615622070. Acesso em: 17 set. 2020 .

SUTTON, R. I. The Process of Organizational Death; Disbanding and Reconnecting. Administrative Science Quarterly, Stanford University, v. 32, p. 542-569, 1987.

SVENINGSSON, Stefan; ALVESSON, Mats. Managing Managerial Identities: Organizational Fragmentation, Discourse and Identity Struggle. Human Relations, $[s . \quad l],$.$\quad v. \quad 56, \quad$ n. $10, \quad$ p. 1163-1193, 2003. DOI https://oi.org/10.1177/00187267035610001. Disponível em: https://journals.sagepub.com/doi/pdf/10.1177/00187267035610001. Acesso em: 19 set. 2020 
TEDESCHI, Richard G.; CALHOUN, Lawrence G. Trauma \& transformation: Growing in the aftermath of suffering. [S. l.]: Sage Publications, 1995.

UHL-BIEN, Mary. Relational Leadership Theory: Exploring the Social Processes of Leadership and Organizing. The Leadership Quarterly, [s. l.], v. 17, n. 6, p. 654-676, 2006. DOI 10.1016/j.leaqua.2006.10.007. Disponível em: https://www.researchgate.net/publication/222704520_Relational_Leadership_The ory_Exploring_the_Social_Processes_of_Leadership_and_Organizing. Acesso em: 19 set. 2020 .

VALE SA. Sobre a Vale. $[S . \quad l$.$] [s.d]. Disponível em:$ http://www.vale.com/brasil/PT/aboutvale/Paginas/default.aspx. Acesso em: 13 jan. 2021.

VALE. Nossa História. $[S . \quad l],$.$\quad [2015?]. Disponível em:$ https://www.youtube.com/watch?v=smna8tI_PNE\&lc=UgzprbdkGSixFIrfgtx4Aa ABAg. Acesso em: 13 jan. 2021.

VERGARA, Sylvia C.; CALDAS, Miguel P. PARADIGMA INTERPRETACIONISTA: A BUSCA DA SUPERAÇÃO DO OBJETIVISMO FUNCIONALISTA NOS ANOS 1980 E 1990. RAE, [s. l.], v. 45, n. 4, p. 66-72, 2005.

VORMITTAG, E. M. P. A. A; OLIVEIRA, M. A; GLERIANO, J.S. Avaliação de saúde da População de Barra Longa afetada pelo Desastre de mariana, Brasil. Ambiente \& Sociedade, [S. l.], 2018.

VRIES, M. F.R K; BALAZS, K. The Shadow Side of Leadership. In: BRYMAN, A et al. The SAGE Handbook of Leadership. London, Great Britain: SAGE Publicatins Ltd, 2011. p. 380-393.

WALSH, I.J.; BARTUNEK, J.M. Rising from the ashes: appreciating and fostering postdeath organizing. Organizational Dynamics, [s. l.], v. 41, ed. 2, p. 89-98, 2012.

WAGNER, Helmut R. Introdução: O Quadro da Sociologia Fenomenológica de Schutz. In: WAGNER, Helmut R. (org.). Fenomenologia e Relações Sociais: Textos Escolhidos de Alfred Schutz. Rio de Janeiro: ZAHAR EDITORES, 1979. p. 13-55.

WEICK, K. E. The Social Psychology of Organizing. 2. ed. [S. l.]: McGraw-Hill, 1979. 294 p. v. 18. ISBN 978-0075548089. 
WEICK, K.E. Enacted sensemaking in crisis situations. Journal of Managment Studies, [S. l.], p. 305-317, 1988.

WEICK, K.E. Organizational redesigning as improvisation. In: HUBER, G.P.; GLICK, W.H. Organizational Change and Redesign. New York: Oxford University Press, 1995. cap. 11, p. 346-383.

WEICK, Karl E.; SUTCLIFFE, Kathleen M.; OBSTFELD, David. Organizing and the Process of Sensemaking. Organization Science, [s. l.], v. 16, n. 4, p. 409-421, 2005. DOI 10.1287/orsc.1050.0133. Disponível em: https://edisciplinas.usp.br/pluginfile.php/4381991/mod_resource/content/0/Organi zing\%20and\%20the\%20Process\%20of\%20Sensemaking.pdf. Acesso em: 17 set. 2020 .

WEICK, K. E. Organizing for Transient Reliability: The Production of Dynamic Non-Events. Journal of Contingencies and Crisis Management, [s. l.], v. 19, n. 1, p. 21-27, 2011. DOI https://doi.org/10.1111/j.1468-5973.2010.00627.x. Disponível em: https://onlinelibrary.wiley.com/doi/full/10.1111/j.14685973.2010.00627.x. Acesso em: 3 mar. 2021.

WINTER, Larissa. Organizational Trauma: A Phenomenological Study of Psychological Organizational Trauma and Its Effect on Employees and Organization. Management, [s. l.], v. 14, n. 2, p. 117-136, 2019. DOI 10.26493/1854-4231.14.117-136. Disponível em: https://www.researchgate.net/publication/339615204_Organizational_Trauma_A_ Phenomenological_Study_of_Psychological_Organizational_Trauma_and_Its_Eff ect_on_Employees_and_Organization. Acesso em: 19 set. 2020.

WORCMAN, Karen. Museu da pessoa: memória do futuro: um desafio. In: NASSAR, Paulo (Org.). Memória de empresa: história e comunicação de mãos dadas, a construir o futuro das organizações. São Paulo: Aberje, 2004. p. 23-30. 


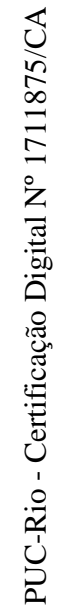

